\title{
Geochemical Analyses of Oils and Gases, Naval Petroleum Reserve No. 3, Teapot Dome Field, Natrona County, Wyoming
}

By Kristin Dennen, William Burns, Robert Burruss and Kendra Hatcher

Any use of trade, firm, or product names is for descriptive purposes only and does not imply endorsement by the U.S. Government

Open-File Report 2005-1275

U.S. Department of the Interior

U.S. Geological Survey 


\title{
U.S. Department of the Interior
}

\author{
Gale A. Norton, Secretary
}

\section{U.S. Geological Survey \\ P. Patrick Leahy, Acting Director}

\section{U.S. Geological Survey, Reston, Virginia 2005}

For product and ordering information:

World Wide Web: http://www.usgs.gov/pubprod

Telephone: 1-888-ASK-USGS

For more information on the USGS - the Federal source for science about the Earth, its natural and living resources, natural hazards, and the environment:

World Wide Web: http://www.usgs.gov

Telephone: 1-888-ASK-USGS

Although this report is in the public domain, permission must be secured from the individual copyright owners to reproduce any copyrighted material contained within this report. 


\section{Table of Contents}

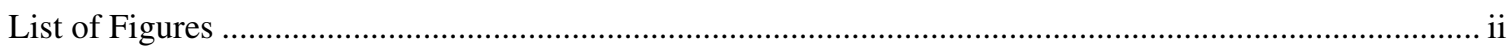

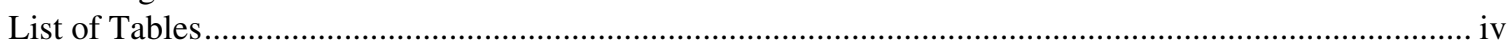

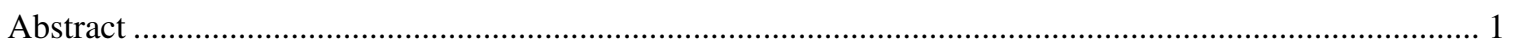

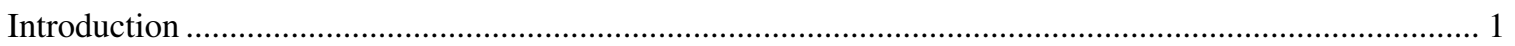

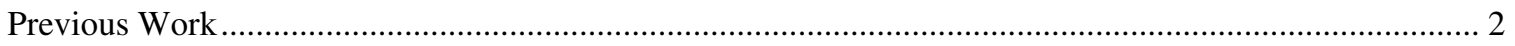

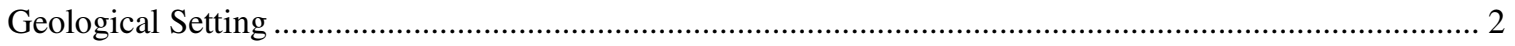

Location . . . . . .

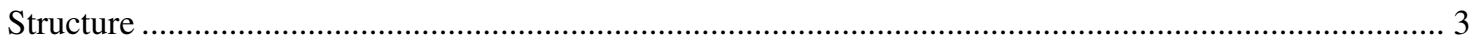

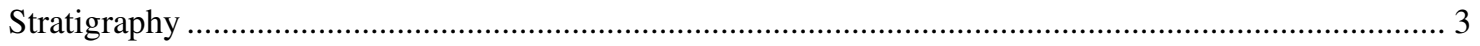

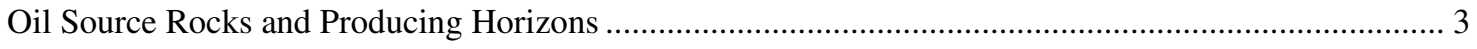

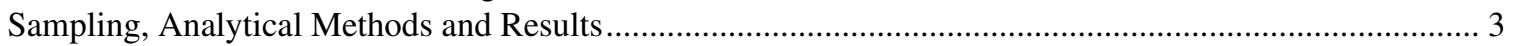

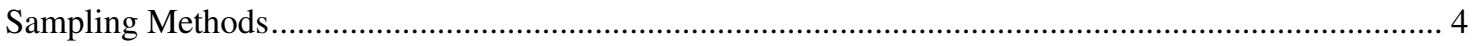

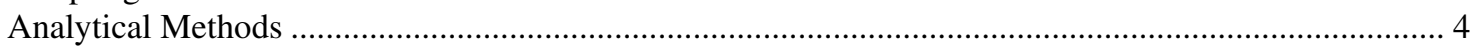

Whole Crude Oil and Surface Hydrocarbon Analyses ……............................................................... 4

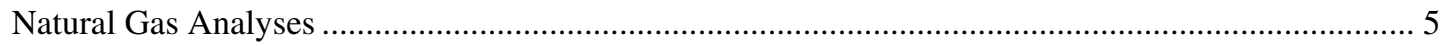

Analysis of Aromatics, Saturates and API Gravity .......................................................................... 5

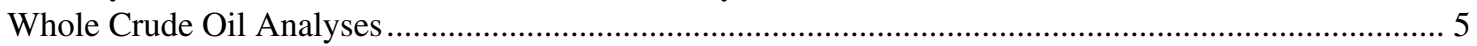

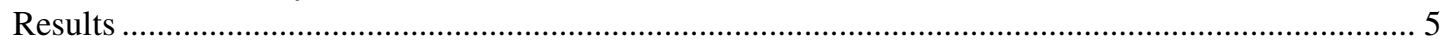

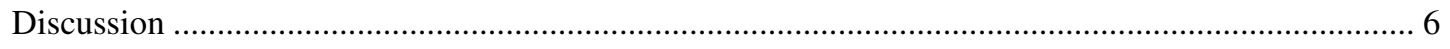

Upper Cretaceous Cody Shale Formation: Shannon Sandstone Member (Figs. 5-14) ........................ 6

Upper Cretaceous Cody Formation: Niobrara and Steele Shales (Figs.15-17) .................................... 7

Upper Cretaceous Frontier Formation: Second and Third Wall Creek Sands (Figs. 18-27) ............... 7

Lower Cretaceous Fall River Formation: Dakota Sandstone (Fig. 28) .............................................. 7

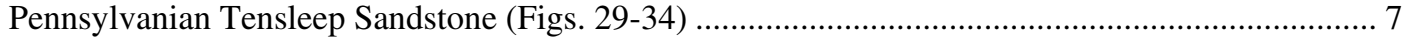

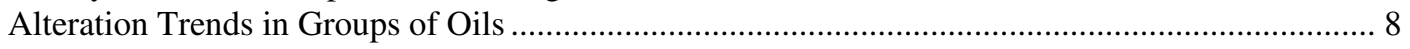

Upper Cretaceous Cody Formation: Shannon Sandstone Group................................................... 8

Upper Cretaceous Frontier Formation: Second and Third Wall Creek Sands ................................. 8

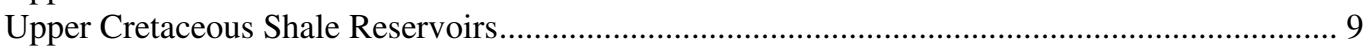

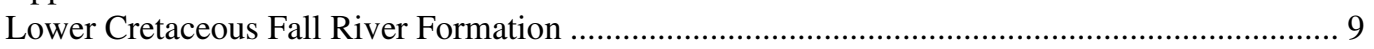

Pennsylvanian Tensleep Sandstone ………………........................................................... 9

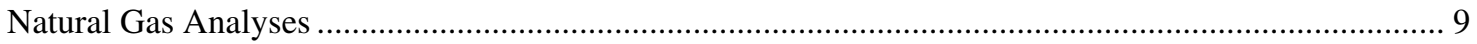

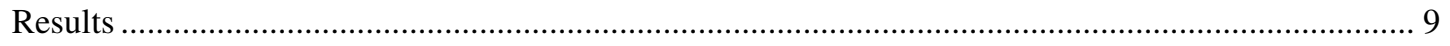

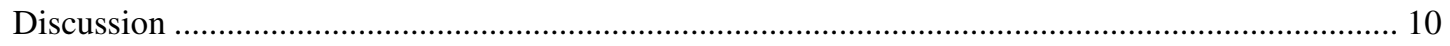

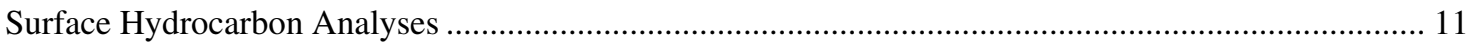

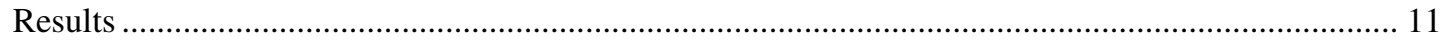

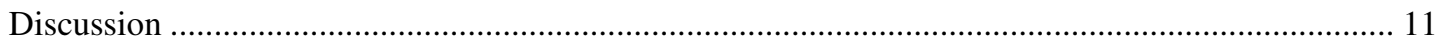

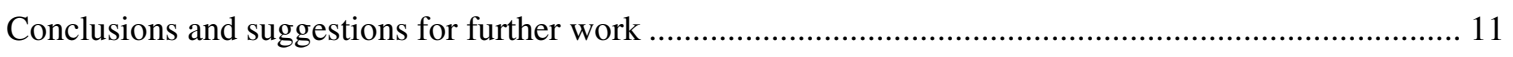

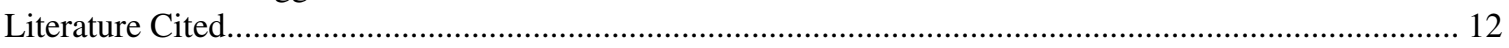

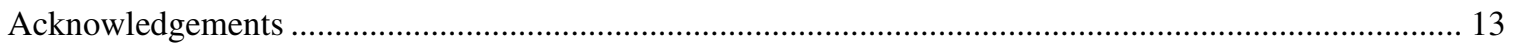




\section{List of Figures}

Figure 1: Study area--Teapot Dome field and adjacent Salt Creek field on the western margin of the Powder River Basin in Natrona, County, Wyoming.

Figure 2: Map of sample locations in the Teapot Dome field.

Figure 3. Stratigraphic column of the Basin Margin Anticline Play of the Powder River Basin Province.

Figure 4a. A whole oil gas chromatogram of a typical, unaltered crude oil.

Figure 4b. A whole oil gas chromatogram of an altered crude oil.

Figure 5: Whole oil gas chromatogram, well 43SX14, producing from the Shannon Sandstone, Teapot Dome field.

Figure 6: Whole oil gas chromatogram, well 52-31SX10, producing from the Shannon Sandstone, Teapot Dome field.

Figure 7: Whole oil gas chromatogram, well 61-36SX10, producing from the Shannon Sandstone, Teapot Dome field.

Figure 8: Whole oil gas chromatogram, well 62-16SX3, producing from the Shannon Sandstone, Teapot Dome field.

Figure 9: Whole oil gas chromatogram, well 62-3SX3, producing from the Shannon Sandstone, Teapot Dome field. Selected peak indentifications: $n$-Cx, normal alkanes where $\mathrm{X}$ is the carbon number; pr, pristane; ph, phytane.

Figure 10: Whole oil gas chromatogram, well 13SX3, producing from the Shannon Sandstone, Teapot Dome field.

Figure 11: Whole oil gas chromatogram, well 38-S-34, producing from the Shannon Sandstone, Teapot Dome field.

Figure 12: Whole oil gas chromatogram, well 77S34, producing from the Shannon Sandstone, Teapot Dome field.

Figure 13: Whole oil gas chromatogram, well 28SX2, producing from the Shannon Sandstone, Teapot Dome field.

Figure 14: Whole oil gas chromatogram, well 24SX2, producing from the Shannon Sandstone, Teapot Dome field.

Figure 15: Whole oil gas chromatogram, well 25STX23, producing from the Steele Shale, Teapot Dome field.

Figure 16: Whole oil gas chromatogram, well 27SHX14, producing from the Niobrara Member, Teapot Dome field.

Figure 17: Whole oil gas chromatogram, well 26STX10, producing from the Niobrara/Steele Shales, Teapot Dome field. 
Figure 18. Whole oil gas chromatogram, Anadarko commingled sample, producing from the 2nd Wall Creek "Sand", Salt Creek field.

Figure 19: Whole oil gas chromatogram, well 32AX10 (J), producing from the 2nd Wall Creek "Sand", Teapot Dome field.

Figure 20: Whole oil gas chromatogram, well 14AX11, producing from the 2nd Wall Creek "Sand", Teapot Dome field.

Figure 20: Whole oil gas chromatogram, well 15AX11 (T), producing from the 2nd Wall Creek "Sand", Teapot Dome field.

Figure 21: Whole oil gas chromatogram, well 83AX10, producing from the 2nd Wall Creek "Sand", Teapot Dome field.

Figure 22: Whole oil gas chromatogram, well 87-AX3, producing from the 2nd Wall Creek "Sand", Teapot Dome field.

Figure 23: Whole oil gas chromatogram, well 38-AX-34, producing from the 2nd Wall Creek "Sand", Teapot Dome field.

Figure 24: Whole oil gas chromatogram, well 36-1AX34, producing from the 2nd Wall Creek "Sand", Teapot Dome field.

Figure 25: Whole oil gas chromatogram, well 84A-20, producing from the 2nd Wall Creek "Sand", Teapot Dome field.

Figure 26: Whole oil gas chromatogram, well 77-AX20, producing from the 2nd Wall Creek "Sand", Teapot Dome field.

Figure 27: Whole oil gas chromatogram, well 72TX33, producing from the Third Wall Creek "Sand", Teapot Dome field.

Figure 28: Whole oil gas chromatogram, well 11DX26 (J), producing from the Fall River Formation (Dakota Sandstone), Teapot Dome field.

Figure 29: Whole oil gas chromatogram, well 55-TPX-10, producing from the Tensleep Sandstone, Teapot Dome field.

Figure 30: Whole oil gas chromatogram, well 67-1-TPX-10, producing from the Tensleep Sandstone, Teapot Dome field.

Figure 31: Whole oil gas chromatogram, commingled sample from treater, producing from the Tensleep Sandstone, Teapot Dome field.

Figure 32: Whole oil gas chromatogram, well 43-2-TPX-10, producing from the Tensleep Sandstone, Teapot Dome field.

Figure 33: Whole oil gas chromatogram, well 72-TPX-10, producing from the Tensleep Sandstone, Teapot Dome field.

Figure 34: Whole oil gas chromatogram, Anadarko commingled sample, producing from the Tensleep Sandstone, Salt Creek field.

Figure 35: Characteristics of Oils and Reservoirs in the Teapot Dome field.

Figure 36: Alteration Trends in Upper Cretaceous Sandstone Reservoirs. 
Figure 37: June 2004 Baseline Gas Sample Profiles.

Figure 38: Natural Gas Plot.

Figure 39: Sources of Methane in Teapot Dome Wells.

Figure 40: Biodegradation of $\mathrm{C}_{2}+$ Gases.

Figure 41: Ozocerite gas chromatogram, surface hydrocarbon sample, Fracture 1, from the Teapot Dome field.

Figure 42: Sediment extract gas chromatogram, surface hydrocarbon sample Fracture1A, from the Teapot Dome field.

Figure 43: Ozocerite gas chromatogram, surface hydrocarbon sample, Fracture 2, from the Teapot Dome field.

Figure 44: Ozocerite gas chromatogram, surface hydrocarbon sample, Fracture 2.1, from the Teapot Dome field.

\section{List of Tables}

Table 1: Selected well information.

Table 2. Selected bulk characteristics of oil samples in the Teapot Dome field.

Table 3: Peak area ratios used in Figures 35 and 36.

Table 4: Molecular and isotopic compositions of gas samples from the Teapot Dome field. 


\title{
Geochemical Analyses of Oils and Gases, Naval Petroleum Reserve No. 3, Teapot Dome Field, Natrona County, Wyoming
}

\author{
Kristin Dennen, William Burns, Robert Burruss, Kendra Hatcher
}

\begin{abstract}
Initial results of this study confirm the presence of two different oil compositions at the Teapot Dome field, 1) oils from Cretaceous reservoirs and 2) oil from the Pennsylvanian Tensleep Sandstone reservoir. Cretaceous oils are less mature, show more evidence of secondary biodegradation and have a mixed terrestrial and marine kerogen source. Moreover, Cretaceous oils can be separated into three different groups, Upper Cretaceous sandstone reservoirs, Upper Cretaceous shale reservoirs, and lower Cretaceous Sandstone reservoirs. The Upper Cretaceous sandstone reservoirs, the Shannon Sandstone and the Second and Third Wall Creek Sands show differences related to gas production, gas-reinjection effects and steam flood effects. The Pennsylvanian Tensleep oil is more mature, less biodegraded, has higher a sulfur content, shows evidence of water washing, and has a marine kerogen source.

Hydrocarbon degradation in the Cretaceous sandstone reservoirs varies along the length of the highly fractured Teapot Dome anticlinal structure--the main trap for hydrocarbons in the Teapot Dome field--which is divided into two domes by an east-west trending fault system. The least degraded samples occur in the southern dome, where reservoirs are deeper and in general, the most degraded are in the northern dome where stratigraphically equivalent reservoirs are shallower. The Pennsylvanian Tensleep oil does not show any variation between the Teapot Dome field and the adjacent Salt Creek field to the north.

Molecular and isotopic composition of gases indicates thermogenic gases may have been altered by two different microbial processes, methanogenesis and secondary bacterial alteration. Also, there are two different types of ozocerite, with possibly two different histories of emplacement.
\end{abstract}

\section{Introduction}

This report presents the preliminary results of geochemical analyses of oil and gas samples taken at the Naval Petroleum Reserve No. 3 (Figs. 1 \& 2). The U.S. Geological Survey (USGS) Energy Resources Program (ERP) is providing these analyses to the U.S. Department of Energy (DOE) as part of a collaborative research effort (Memorandum of Understanding, 2004). This site, also known as the Teapot Dome oil field, has been designated as a possible long term field-scale test site for development and assessment of $\mathrm{CO}_{2}$ sequestration methods (Orr, 2004). In preparation for this test, geochemical studies of reservoir characteristics are required to provide a baseline against which to evaluate the effects caused by experimentally injected $\mathrm{CO}_{2}$. In addition, the USGS ERP has examined surface hydrocarbons associated with calcite fractures to provide estimates of the timing of emplacement and possible migration pathways of reservoir fluids to the surface. 
Geochemical analyses provided by the USGS ERP in this report include gas chromatography of whole oils from 29 wells in producing horizons in the Teapot Dome field, and two oil samples from wells producing in the Salt Creek oil field, analysis of three surface hydrocarbon samples and an extract of one surface hydrocarbon associated sediment sample, molecular and stable isotopic composition of gases from six wells in the Teapot Dome field, and carbon stable isotopic compositions of the saturated and aromatic hydrocarbon fractions of the whole oils.

\section{Previous Work}

There is a wealth of information relating to the Teapot Dome field due to the age of the field and the intense interest in the possibility of loss of oil from the field by "drainage" from private wells outside the boundaries of the reserve, related to the Teapot Dome Oil Scandal in the 1920's. Curry (1977) provides a detailed summary of the history of the field up through the 1970's. According to Curry (1977), oil seeps were known in the area during the early 1800's. The USGS conducted the first detailed study of the Teapot Dome field (Wegemann, 1911).

Previous to this, studies done by the University Of Wyoming School Of Mines of the Teapot Dome field (Knight and Slosson 1896) were included with the much larger Salt Creek oil field and the area was called the Salt Creek "district". Wegemann (1911) included USGS analyses of oils from two producing formations, three Wall Creek Sand oils and two Shannon Sandstone oils in the Salt Creek field.

Other early analyses from the Salt Creek-Teapot Dome area published by the USGS include analyses of the waters from the producing formations, including the Shannon Sandstone, the Wall Creek Sands, the Muddy Sandstone, the Dakota Sandstone, Lakota Formation, Morrison Formation, the Sundance Formation and the Tensleep Sandstone by Stabler (1931)(See Fig. 2). His work was part of the Thom and Spieker survey in 1931 of the Teapot Dome field, begun immediately after the field was restored to the Department of the Navy as Naval Petroleum Reserve No. 3.

Hunt (1953) and Wenger and Reid (1958) described two different types of oils found in Wyoming and included analyses of oils from some of the formations which produce oil in the Teapot Dome and Salt Creek fields. Momper and Williams (1979) provided results of geochemical analyses of 235 oil samples which were used to interpret the filling history of the reservoirs and the sources for the oils in the Powder River Basin. Geology and structure in the Salt Creek-Teapot Dome area have been mapped by Wegemann $(1911,1918)$, Thom and Spieker (1931), and Horn (1959).

Currently, the Teapot Dome field is still owned by the federal government, and the DOE's Rocky Mountain Oilfield Testing Center (RMOTC), operates it as an oilfield-testing site. Opsal (1997) summarizes field tests at the Teapot Dome field. Test reports and field applications notes are available at the RMOTC website -- http://www.rmotc.com. The adjacent Salt Creek field has a history of enhanced oil recovery (EOR), starting in 1926 (Bargas et al, 1992).

Anadarko Petroleum currently owns the Salt Creek field and is using $\mathrm{CO}_{2}$ for EOR. (Leach, 2003)

\section{Geological Setting}

\section{Location}

The Teapot Dome field and the adjacent giant Salt Creek field are faulted domes in the Salt Creek anticline on the southwestern margin of the Powder River Basin, north of Casper in Natrona County, Wyoming. These fields are included in the Basin Margin Anticline Play of the 
Powder River Basin petroleum province (Dolton and Fox, 1996). Figure 1 shows a map of the area in relation to the Powder River Basin.

\section{Structure}

Major deformation in the Powder River Basin started in the early Eocene and may have continued into the Miocene (Strickland, 1958). The displacement started by compression from the west, resulting in reverse faults at depth, tensional fissures on top of the anticlinal folds and thin downdropped blocks (Thom and Spieker 1931). Wegemann $(1911,1918)$ mapped an eastwest trending normal fault separating the Teapot Dome field into two domes. (See Fig. 2.) The northern dome is displaced more than 200 feet eastward and upward relative to the southern dome. Anticlinal traps, fault closures and combinations of the two are typical in the Teapot Dome field as well as in other fields of this type, including the adjacent Salt Creek field (Dolton and Fox, 1996).

\section{Stratigraphy}

Paleozoic strata overlying Precambrian basement in the Teapot Dome field consist of relatively thin interbedded successions of sandstones, limestones, dolomites, shales and evaporites of marine, dune and interdune origin. (Fig. 3 shows a generalized stratigraphic column of the area.) The Pennsylvanian Tensleep Sandstone, which is one of the three major producing horizons in the Teapot Dome field is partially eolian in origin, and is one of several Tensleep Sandstone reservoirs producing oil in Wyoming. The Paleozoic section is overlain by thick, mostly terrigenous Triassic and Jurassic sedimentary rocks. Although currently non-productive in the Teapot Dome field, the Upper Jurassic Sundance Formation (marine) produces oil in the Salt Creek oil field.

Cretaceous sedimentary rocks grade from fluvial sandstones and shales to marine shales and sandstones. The two major producing reservoirs in the Upper Cretaceous in the Teapot Dome field are the Shannon Sandstone member of the Cody Shale and the Second Wall Creek Sand of the Frontier Formation (Fig. 3). The Frontier contains three Wall Creek Sands, of which the Second and Third Wall Creek Sands produce oil and gas. Oil and gas have also been produced from fractured Upper and Lower Cretaceous shales, including the Niobrara and the Steele Shale and from the non-marine sandstone members of the Lower Cretaceous Thermopolis Shale, the Muddy Sandstone and the Dakota Sandstone.

\section{Oil Source Rocks and Producing Horizons}

The Permian Phosphoria Formation probably supplied oil by long range migration to the Pennsylvanian Tensleep Sandstone oil reservoir (Hunt, 1953; Sheldon, 1967; Momper and Williams, 1979). The major oil source rock for the Cretaceous sandstone reservoirs, the Dakota Sandstone, the Muddy Sandstone, the Frontier Formation (the Wall Creek Sands), and the Shannon Sandstone, is the Lower Cretaceous Mowry Shale, with minor contributions from shales in the Niobrara formation, the Frontier Formation and the Steele Shale (Hunt, 1953; Burtner and Warner, 1984; Momper and Williams, 1979).

\section{Sampling, Analytical Methods and Results}

Figure 2 shows oil sample locations in relation to some of the major faults in the Teapot Dome field. We chose to sample a distribution of wells which would give the broadest possible 
coverage of the Teapot Dome field. The 30 wells sampled include those producing from the Shannon Sandstone, the Steele Shale, and the Niobrara Member of the Cody Shale Formation; the Second Wall Creek Sand and the Third Wall Creek Sand in the Frontier Formation; the Muddy Sandstone (gas sample only); the Dakota Sandstone in the Fall River Formation; and the Tensleep Sandstone (see Table 1). Samples in multiple wells from the three major producing formations, the Tensleep Sandstone, the Shannon Sandstone and the Second Wall Creek Sand, were collected for comparison purposes. The location of the surface hydrocarbons collected for this study is also included on Figure 3. Anadarko Petroleum provided commingled samples from wells at the Salt Creek field producing from the Second Wall Creek Sand and Tensleep Sandstone

\section{Sampling Methods}

RMOTC field personnel, with the assistance of USGS ERP staff, collected oil and gas samples from the wellhead or the oil and gas separator of individual wells in the Teapot Dome field. Two oil samples from the Tensleep Sandstone in the Teapot Dome field were collected from the inlet oil line at the treater for water removal. One Tensleep Sandstone sample is a commingled sample taken from this inlet line. When the oil samples contained water, the water was collected along with the oil and separated at the USGS ERP lab in Reston, Virginia, by siphoning off the oil or draining off the water in a separatory funnel. All the oil samples were collected in metal cans whereas oil and water samples were collected in pre-cleaned glass bottles. Gas samples were collected in cylinders provided by Isotech Laboratories. The Salt Creek oil samples were collected in metal cans from inlets to stock tanks by Anadarko personnel.

Surface hydrocarbon samples were collected with help from RMOTC personnel. A backhoe cleared the sediment from an outcrop surface, exposing one of the fractures, which contained calcite and ozocerite ${ }^{1}$. Another sample was hand dug with a shovel. Ozocerite and associated calcite and sedimentary rocks were collected individually and placed in sealed plastic sample bags.

\section{Analytical Methods}

\section{Whole Crude Oil and Surface Hydrocarbon Analyses}

Oil samples were analyzed at the USGS ERP in Reston, Virginia, and in Denver, Colorado. Whole oil samples only were analyzed in Reston, Virginia by gas chromatography using a Hewlett/Packard Model 6890 (HP6890) gas chromatograph with a $60 \mathrm{~m} \times 0.32 \mathrm{~mm}$ x $0.25 \mu \mathrm{m}$ DB-1 fused silica capillary column with helium carrier gas velocity at $36 \mathrm{~cm} / \mathrm{sec}$ and an FID detector. The oven was programmed to increase temperature from 34 to $320^{\circ} \mathrm{C}$ at $6^{\circ} \mathrm{C} /$ minute. The temperature was held isothermal at $320^{\circ} \mathrm{C}$ for $20 \mathrm{~min}$. Injections were manual, $0.1 \mu \mathrm{l}$ split with a split ratio of $200: 1$ and a split flow of $15 \mathrm{ml} / \mathrm{min}$.

Surface hydrocarbon samples were prepared in Reston, Virginia, as follows: 1) Ozocerite samples and the sediment sample were weighed into glass vials and a weighed amount of GC capillary chromatography grade dichloromethane was added; 2) the vials were capped with PTFE caps, shaken and allowed to sit overnight; 3 ) the samples were well shaken just before analysis and allowed to sit for a short period so any grit could settle, and 4) an aliquot of $0.1 \mu \mathrm{l}$ was injected into the Hewlett/Packard Model 6890 (HP6890) gas chromatograph running under the same conditions as described above for the whole oil samples.

\footnotetext{
${ }^{1}$ Ozocerite is a solid wax usually resulting from the migration of oil high in saturated hydrocarbons to a temperature low enough to cause the oil to solidify. (Hunt, 1996)
} 
The whole crude oil and surface hydrocarbon chromatograms acquired in Reston were integrated using Justice Laboratory Software's Chrom Perfect Spirit version 5.5 and a method file which subtracted a baseline chromatogram (an injection-less chromatogram) run on the same day under the same conditions the oils were analyzed. After the baseline chromatogram was subtracted, the peaks, up to $n$ - $\mathrm{C}_{9}$, were integrated from the horizontal baseline. After $n-\mathrm{C}_{9}$, the baseline was then reset to integrate from peak valley to peak valley. The profiles of the crude oils are presented as integrated peak heights in millivolts (y-axis) versus retention time in minutes (xaxis) (for example, see Fig. 4). Results are shown in Figs. 5-38 and calculated peak area ratios are shown in Table 3.

\section{Natural Gas Analyses}

Natural gas samples were analyzed at Isotech Laboratories, Inc., Champaign, Illinois, for molecular composition by gas chromatography and for stable isotopic composition by isotope ratio mass spectrometry. Carbon isotopic composition was determined for methane $\left(\mathrm{C}_{1}\right)$, ethane $\left(\mathrm{C}_{2}\right)$, propane $\left(\mathrm{C}_{3}\right)$, and $n$-butane $\left(\mathrm{C}_{4}\right)$. Also, hydrogen isotopic composition (deuterium) was determined for methane, and isotopic composition was determined for molecular nitrogen. Carbon isotope ratios are reported in standard format as per mil deviation relative to the Vienna Peedee belemnite standard (VPBD); deuterium is reported relative to Vienna standard mean ocean water (VSMOW) for both gases and oils. Nitrogen isotope ratios are reported relative to air. Analytical results are shown in Table 4.

\section{Analysis of Aromatics, Saturates and API Gravity}

Crude oils were fractionated and analyzed by the USGS ERP in Denver, Colorado. API gravity of the oils was determined gravimetrically. Oils were fractionated by dilution in $n$ heptane to remove asphaltenes. The maltene fraction of the solution was further fractionated by column chromatography on silica gel by selective elution with heptane, benzene, and benzenemethanol $(1: 1 \mathrm{v} / \mathrm{v})$ to collect the saturated hydrocarbon, aromatic hydrocarbon, and resin (nitrogen-, sulfur-, and oxygen- [NSO] compounds) fractions, respectively. The carbon stable isotope composition of an aliquot of the saturated and aromatic hydrocarbon fractions was determined on a Micromass Optima isotope ratio mass spectrometry system.

Gas chromatography of the whole oil, and the saturated and aromatic hydrocarbon fractions was performed in Denver under conditions similar to those in Reston. (An HP6890 gas chromatograph with a $60 \mathrm{~m} \times 0.32 \mathrm{~mm} \times 0.25 \mu \mathrm{m}$ DB-1 fused silica capillary column with helium carrier gas velocity at $35 \mathrm{~cm} / \mathrm{sec}$ and an FID detector was used. The oven was ramp programmed from 40 to $330^{\circ} \mathrm{C}$ at $4.5^{\circ} \mathrm{C} / \mathrm{min}$ and held isothermal at $330^{\circ} \mathrm{C}$ for $15 \mathrm{~min}$.) Injections for the saturate and aromatic fractions were $1 \mu \mathrm{l}$ split-less. For the whole oil, the injection was $1 \mu \mathrm{l}$ split with a split flow of $200 \mathrm{ml} / \mathrm{min}$. Selected results are shown in Table 2.

\section{Whole Crude Oil Analyses}

\section{Results}

Whole oil gas chromatograms for oils from the wells sampled in this study are shown in Figures 5-34. The information shown in Table 3 is calculated from peak areas. Peak area ratios are used in the diagrams shown in Figures 35 and 36. Reproducibility of peak area ratios was determined during experimental runs of an in-house standard crude oil and is reported at the bottom of Table 3 . 
Whole crude oil gas chromatography is a relatively fast and inexpensive screening method used here to "fingerprint" individual oil samples and groups of analyzed oils. A whole oil chromatogram of a crude oil appears as a complex collection of different sized peaks, all representing molecular components. Peak heights as measured on the $y$-axis are used to estimate the concentration of the components and are most useful for visual inspection. The $\mathrm{x}$-axis is a time scale and as described in methods above, each particular time represents a programmed increase in temperature. The time at which a peak appears is determined by the boiling point and structure of the particular component. The larger and heavier the molecule (the more carbons it has), the higher its boiling point and the later it appears in the chromatogram. A component can be therefore identified by the time at which its peak appears.

The pattern of peaks in the whole oil gas chromatogram of a typical crude oil (Fig. 4a) is dominated by the normal alkanes ( $n$-alkanes) or saturated hydrocarbons with single bonded carbon atoms, the smallest and simplest of which is methane, $\mathrm{CH}_{4}$, with one carbon atom. The $n$ alkane series increases in complexity according to the formula $\mathrm{C}_{n} \mathrm{H}_{2 n+2}$, and the peaks appear on the chromatogram at regular intervals. $\mathrm{N}$-alkanes are referred to by their number of carbon atoms, for example, $n-\mathrm{C}_{6}$ is the designation for Hexane.

An oil which appears "normal" or unaltered by secondary processes has a profile in which hydrocarbons are represented in the range of $\mathrm{C}_{2}$ to $\mathrm{C}_{35}$, with higher peak heights in the gas range $\left(n-\mathrm{C}_{2}\right.$ to $\left.n-\mathrm{C}_{6}\right)$ and gasoline range $\left(n-\mathrm{C}_{7}\right.$ to $\left.n-\mathrm{C}_{15}\right)$ tapering downwards towards the higher $\mathrm{C}$ numbers. (See Fig. 4a.) Between the $n$-alkane peaks are a great many other peaks. All these compounds, including the $n$-alkanes, are residual carbon skeletons of substances produced by living organisms and represent a record of the chemical transition from biological material to crude oil. They are sensitive to many factors, among which are lithology/depositional environment and thermal maturity of the oil source rock, age of the oil, and maturation processes within the oil reservoir.

If the gas range peaks $\left(n-\mathrm{C}_{2}\right.$ to $\left.n-\mathrm{C}_{6}\right)$ are diminished compared to the rest of the profile, the oil may have been altered by water washing and migration. Water washing impacts these gas range peaks due to the greater relative solubility in water of these components (Hunt, 1996) Water washing may be an indicator of migration over long distances (Mauk and Burruss, 2002). A diminished profile in the gasoline range $\left(n-\mathrm{C}_{6}\right.$ to $\left.n-\mathrm{C}_{15}\right)$ can indicate biodegradation of the oils in the reservoir due to the greater preference bacteria have for these components (Fig 4b.) (Connan, 1984). Of particular interest are two biological markers (biomarkers), pristane and phytane, derived from chlorophyll. Pristane appears as the second half of a doublet with $n-\mathrm{C}_{17}$, and phytane as the second half of the doublet with $n-\mathrm{C}_{18}$.

\section{Discussion}

Upper Cretaceous Cody Shale Formation: Shannon Sandstone Member (Figs. 5-14)

We analyzed ten whole oil samples from wells producing in the Shannon Sandstone. This is the youngest and shallowest producing horizon of the wells sampled for this study (the average producing horizon ranges from 174 to $733 \mathrm{ft}$, Table 1). Only one sample, 43SX14 (Fig. 5), has a profile similar to that in an unaltered whole crude oil, as described above, similar to an oil from a much deeper Shannon Sandstone reservoir in the Hartzog Draw Field, Campbell County, Wyoming (Thompson,1987).

In the rest of the samples (Figs. 6-14) there is depletion of $n$-alkane peak heights between $n-\mathrm{C}_{7}$ and $n-\mathrm{C}_{17}$ with a similar profile to $43 \mathrm{SX} 14$ resuming at $n-\mathrm{C}_{18}$. All of these oils exhibit some degree of secondary biodegradation. Four of these wells are in an area said to be affected by a steam flood operation (RMOTC personal communication, 2005). Olsen et al, 1993, provide a map of the steam flooded area in their description of the operation. The steam flood in the 
Shannon Sandstone was performed in the central part of the southern dome, which is where all the oil samples in this study from the Shannon Sandstone were taken, with the exception noted above. The profiles of all the Shannon Sandstone wells we sampled, except 43SX14 --away from the steam flood area-- are similar, so they may all have been affected by the steam flood.

\section{Upper Cretaceous Cody Formation: Niobrara and Steele Shales (Figs.15-17)}

We collected and analyzed one oil sample from the Steele Shale, one from the Niobrara shale and one from an open-hole well producing from both the Niobrara and Steele Shales. The chromatograms have a distribution of $n$-alkane peak heights expected in unaltered oil samples.

\section{Upper Cretaceous Frontier Formation: Second and Third Wall Creek Sands (Figs. 18-27)}

There are 9 whole oil samples from wells producing in the Second Wall Creek Sand in the Teapot Dome field and one collected from the adjacent Salt Creek field. Visual inspection reveals two groups of Wall Creek sand samples, a less altered group (Figs. 18-21) with well locations clustering around the middle of the southern dome of the Teapot Dome field (Fig. 3) and, the sample from the Salt Creek field. The commingled sample from the Second Wall Creek Sand at the Salt Creek field (Fig. 18) is the most "normal" looking of this group. The gasoline range peaks $\left(n-\mathrm{C}_{7}\right.$ to $\left.n-\mathrm{C}_{15}\right)$ are generally higher than the heavier $n$-alkane peaks. The sample from well 32AX10 (Fig. 19) exhibits the deltoid profile of an oil affected by evaporative fractionation described by Thompson (1987), which is consistent with the fact that it is a gas producing well. A gas sample was taken from this well and is discussed in the section on gas analyses.

In the remaining five samples (Figs. 23-26), there is diminished height in $n$-alkane peaks between $n-\mathrm{C}_{10}$ and $\mathrm{n}-\mathrm{C}_{17}$ and pristane is higher than $n-\mathrm{C}_{17}$. The one sample we analyzed from the Third Wall Creek Sand at the Teapot Dome field (Fig. 27) is similar to these five samples. These samples are from wells located to the north of the first group (Fig. 3).

\section{Lower Cretaceous Fall River Formation: Dakota Sandstone (Fig. 28)}

There is one oil sample from the Dakota Sandstone producing horizon (average depth $4964 \mathrm{ft}$ ) in the Teapot Dome field. It exhibits a normal profile, although the gas range appears slightly depleted relative to methylcyclohexane. This may be due to the fact that the sample was collected from a gas producing well.

\section{Pennsylvanian Tensleep Sandstone (Figs. 29-34)}

There were six whole oil samples from wells producing from the Pennsylvanian Tensleep Sandstone, including one commingled sample from the Salt Creek field. The Tensleep Sandstone reservoir is the deepest sampled in this study, with depths to the producing horizons in the sampled wells ranging from 5413 to $5528 \mathrm{ft}$. Five of the six samples have very similar profiles. (One sample, 55-TPX-10 having mostly water, had to be dissolved in solvent to be analyzed (Fig. 29). The normal alkanes below $n-\mathrm{C}_{8}$ are severely diminished. This profile indicates biodegradation.) The five "normal" samples demonstrate methylcyclohexane lower in height than $n$ - $\mathrm{C}_{7}$. Normal alkanes in the $n-\mathrm{C}_{9}$ through $n-\mathrm{C}_{11}$ region have the highest peak heights in all of the Tensleep Sandstone samples, including 55TPX10. The gas range hydrocarbons appear diminished indicative of water washing associated with the very high water to oil ratio of fluids produced from these wells. Also the oil in the Tensleep Sandstone is thought to have migrated from outside the basin (Sheldon, 1967; Momper and Williams, 1979). There is apparently little variation in the oils from the Tensleep Sandstone between the Teapot Dome field and the Salt Creek field. 


\section{Alteration Trends in Groups of Oils}

Figure 35 following Shanmugam (1985) summarizes characteristics of the sampled oils in the Teapot Dome field utilizing the biomarkers, pristane and phytane and their ratios to the $n$ alkanes, $n$-C17 and $n$-C18. The basis for this diagram is the fact that during secondary bacterial degradation of oil, the straight chain hydrocarbons, ( $n$-alkanes) are preferentially attacked, rather than the isoprenoids, a class of organic compounds with aromatic rings (which includes pristane and phytane) and that the lower weight hydrocarbons are preferred to the higher ones $\left(n-\mathrm{C}_{17}\right.$ is preferred to $n-\mathrm{C}_{18}$ and pristane is preferred to phytane). The pristane:phytane ratio is also used as an indicator of the depositional environment of the oil source material (kerogen) because reducing marine environments favor the formation of phytane and oxidizing terrestrial environments favor the formation of pristane. (Shanmugam, 1985) This diagram also utilizes the hypothesis that the more "mature" an oil source rock is (the higher the possibility that all the hydrocarbons have been expelled) the higher the amounts of $n$-alkanes relative to isoprenoids due to thermal cracking of the kerogen to less complex, lower weight hydrocarbons.

Another way to illustrate the different geochemical characteristics of the oils in the Teapot Dome field is shown in Figure 36, which utilizes the ratio of pristane:phytane plotted against the ratio of $n-\mathrm{C}_{7}$ :methylcyclohexane. The idea behind the $n-\mathrm{C}_{7}$ :methylcyclohexane ratio is similar to that above in that oils from more mature source rocks have a higher ratio of n-alkanes ( $n$-C7) to isoprenoids (methylcyclohexane) (Thompson, 1982). This diagram serves to confirm the trends observed in Figure 35 and emphasizes secondary biodegradation trends.

Consistent with the stratigraphy and observations made by Wegemann $(1911,1918)$, Momper and Williams (1979) and others, there are two distinct groups of oils (Fig. 35). The oil from Cretaceous reservoirs appears to be derived from a mixed terrestrial and marine source of kerogen and the oil from the Pennsylvanian Tensleep Sandstone appears to have been derived from a marine source of kerogen. The Cretaceous oils can be further subdivided into those oils from Upper and Lower Cretaceous Sandstones and those from Upper Cretaceous Shales (Fig. 36).

\section{Upper Cretaceous Cody Formation: Shannon Sandstone Group}

The two most altered oils we analyzed from the Shannon Sandstone are from the wells 77S34 and 38S34 (Figs. 35 and 36). These are the most northern wells in the Shannon Sandstone sampled for this study. They also appear to be on the same fault block (see Fig. 2). The least altered Shannon Sandstone sample is from the southern most and deepest Shannon Sandstone well sampled, well 43SX14.

All the samples collected from the Shannon Sandstone reservoir came from the southern dome of the Teapot Dome field, and with the exception of 43SX14, may be affected by a steam flood operation, as noted in the visual inspection discussion above. Wells producing from the Shannon Sandstone in the northern dome of the Teapot Dome field need to be sampled and analyzed in order to examine possible effects of the steam flood operation and associated injected chemicals described in Olsen et. al. (1993) and to detect any oriented biodegradation trends, possibly similar to the Wall Creek Sands, described in the section below, with a much greater increase in alteration to the north.

\section{Upper Cretaceous Frontier Formation: Second and Third Wall Creek Sands}

The least altered of the Wall Creek Sand oils are from wells 32AX10, 15AX11 and 14AX11(Figs. 35 and 36) However, 15AX11 and 14AX11 are in close proximity to 83AX10, a gas re-injection well, so the oil compositions may have been modified by the re-injection of gas. Well 15AX11 was also part of a hydrofracture experiment in 1996 (Doyle, 1998). Oils from wells 361AX34, 77AX20, and 84A20 are the most biodegraded. The spread in the plot for the Wall Creek Sand group of reservoirs in Figure 35 relative to the oils from the Shannon Sandstone wells 
may be explained by the fact that the Wall Creek Sand reservoir was sampled in the northern dome of the Teapot Dome field, and the Shannon reservoir was not.

\section{Upper Cretaceous Shale Reservoirs}

The Niobrara and Steele reservoir oils are the least degraded of the Upper Cretaceous oils and have very similar characteristics (Fig. 36). These wells are all in the southern dome of the Teapot Dome field (see Fig. 2).

\section{Lower Cretaceous Fall River Formation}

The oil coming from the Dakota Sandstone reservoir is the least biodegraded of the Cretaceous sandstone reservoir oils and is from the southernmost well sampled in this study where the reservoir is at an average $4964 \mathrm{ft}$.

\section{Pennsylvanian Tensleep Sandstone}

The oils from the Tensleep Sandstone formation are completely different from the Cretaceous oils (Fig. 35), with a pristane: phytane ratio of less than 1 and an average wt. \% sulfur of 1.4 (see table 2). Therefore, they plot in the area indicating a marine kerogen source, which is consistent with the suggestion that the Phosphoria Formation may be a source rock for the oil in Tensleep Sandstone. The oils are found in wells in the middle of the southern dome of the Teapot Dome field (Fig. 2).

\section{Natural Gas Analyses}

\section{Results}

Table 4 shows molecular and isotopic analyses of the natural gas samples from the Teapot Dome field.

Profiles of the concentrations of components in the gas samples are shown in Figure 37. Of the five producing formations sampled, the Muddy Sandstone produces gas with the highest methane content $(87.4 \%)^{2}$. All the gas samples have measurable amounts of non-hydrocarbon trace gases. The Dakota Sandstone gas has less than 50\% methane $(46.7 \%)$ and the most hydrogen $(0.03 \%)$. The Third Wall Creek Sand well sample, 72-TX-33, has the highest concentrations of carbon dioxide (4.31\%), nitrogen (5.64\%), and argon (0.06\%).

Figure 38 shows a "natural gas plot" of $\delta^{13} \mathrm{C}$ versus reciprocal $n$-alkane number following the research of Chung, Gormley and Squires (1988). This plot is based on the assumption that natural gases are generated by thermal cracking of isotopically homogenous parent kerogen molecules. For example, the cracking process from butane to propane should theoretically result in isotopically lighter propane, because the ${ }^{12} \mathrm{C}-{ }^{12} \mathrm{C}$ bond is easier to break than the ${ }^{12} \mathrm{C}-{ }^{13} \mathrm{C}$ bond, thus enriching the cracked molecules in the lighter isotope. A natural gas plot of purely thermally cracked gas should be a straight line with methane having the most negative $\delta^{13} \mathrm{C}$ values.

\footnotetext{
${ }^{2}$ NOTE: In plots of the gas analyses, the sample from the Muddy Sandstone (well 85 MX 10) and the sample from the gas plant inlet were almost identical. The gas is a mixture of gases produced from the Muddy Sandstone and the Second Wall Creek Sand. RMOTC provided molecular analysis of a gas sample from the inlet for a particular day and time (Table 3). Also gas is reinjected into the 85MX10 well after propane has been removed. Because all these analyses are so similar, only the gas sample from the Second Wall Sand well is used for plotting in Fig. 38.
} 
Deviations from the linear relationship of progressive isotope enrichment with decreasing carbon number are usually the result of mixing or microbial alteration. Such a deviation appears in the natural gas plot of the gas sample from the Third Wall Creek Sand in well 72TX33. All the isotope values for this sample are more enriched in $\delta^{13} \mathrm{C}$ (less negative) than the values for the other samples and relative to $n$-butane, $\delta^{13} \mathrm{C}$ values for propane and ethane are elevated, with the slope of the line between $n$-butane and propane being reversed or positive. Another deviation appears in the slope of the plot for the gas sample from the Niobrara/Steele Shale. Although the $n$-butane and propane isotopic values are similar to the other wells, with a similar slope, there is a downward deflection of the line from ethane to methane.

Figure 39 shows the relationship of the isotopes of the components of methane $\delta^{13} \mathrm{C} \mathrm{CH}_{4}$ and $\delta^{2} \mathrm{H} \mathrm{CH}_{4}$, based on the work of Whiticar (1999) and the natural abundances of isotopic values of $\delta^{13} \mathrm{C}$ and $\delta^{2} \mathrm{H}$ found in methane originating by different processes. This diagram indicates that the methane in the well producing from the Niobrara/Steele Shale is composed of a greater amount of gas from bacterial reduction of $\mathrm{CO}_{2}$ relative to the other gases. The methane from the other wells in this study are indicated as being a result of mixed microbial and thermogenic processes, with more input from thermogenic processes than the gas from the Niobrara/Steele Shale well.

Figure 40 shows biodegradation of gases according to the scheme of Wenger (2002). This plot illustrates the idea that because bacteria prefer to oxidize propane relative to butane, bacterially degraded gases will exhibit more positive propane $\delta^{13} \mathrm{C}$ values relative to their $\delta^{13} \mathrm{C}$ values for butane. For more highly biodegraded gases, the difference between the $\delta^{13} \mathrm{C}$ propane and $\delta^{13} \mathrm{C}$ butane values divided by the $\delta^{13} \mathrm{C}$ propane value will be a positive number, as shown for the Third Wall Creek Sand sample (well 72TX33).

\section{Discussion}

The perturbation in the slope of the line in the natural gas plot for the Third Wall Creek Sand gas (Fig. 38) may be due to secondary bacterial alteration of petroleum. This is consistent with the results shown in Figure 41 where propane is shown to be bacterially degraded relative to $n$-butane in this sample. The whole oil gas chromatogram from this well, 72TX33, indicates that it is among some of the most bacterially degraded oil in the Upper Cretaceous Wall Creek Sand reservoirs we sampled (Figs. 27, 35 and 36).

The gas from the Niobrara/Steele Shale is in the range of the natural abundances found in bacterially generated methane (Fig. 39) and it is also the least of the bacterially degraded samples in Figure 40. The downward deflection of the isotopic values of ethane and methane for this well in the natural gas plot (Fig. 38) may be due the primary process of methanogenesis, rather than secondary bacterial degradation of higher weight hydrocarbons. The whole oil chromatogram of the oil sample from the Niobrara/Steele Shale supports this interpretation; because it is one of the least degraded oils in the Upper Cretaceous reservoirs we sampled (Figs. 17 and 35). Therefore there may be two or more different processes generating the gases in the wells at Teapot Dome. However Martini et. al. (2003) have shown that differentiating among natural gas sources can be very complicated, and more work needs to be done before these processes can be linked to specific reservoirs. 


\section{Surface Hydrocarbon Analyses}

\section{Results}

Samples from Fracture 1 and associated oil stained rock 1A (Figs. 41 and 42) have measurable $n$-alkane peaks in the range $n-\mathrm{C}_{14}$ through $n-\mathrm{C}_{40}$ for the ozocerite and $n$ - $\mathrm{C}_{16}$ through $n$ $\mathrm{C}_{40}$ for the rock extract. The pristane: phytane ratios for these samples are 3.8 and 2.2 respectively. In contrast, samples from Fractures 2 and 2.1 have well defined $n$-alkane peaks starting at $n-\mathrm{C}_{26}$ through $n-\mathrm{C}_{40}$ and no pristane or phytane. (Figs. 43 and 44 ). The surface hydrocarbon samples dissolved completely in the solvent to an amber colored liquid. The associated rock extract was a colorless liquid. (See figure 2 for sample location)

\section{Discussion}

The whole oil gas chromatogram profiles for Fractures 2 and 2.1 fit the description of mineral wax deposits, ozocerite, found in the Teapot Dome field by Wegemann (1918). They are almost purely heavier $n$-alkanes and according to Hunt (1996) are the result of the thickening of high wax oils after migration to conditions where the temperature is low enough to cause crystallization of the saturated hydrocarbons. The Fracture 1 associated hydrocarbons, which have measurable pristane and phytane and some lighter $n$-alkane peaks, may not be mineral waxes and could be younger than the hydrocarbons in Fractures 2 and 2.1. Because all the Cretaceous oils analyzed for this study have pristane:phytane ratios of greater than 1 (Table 3), this suggests a Cretaceous source rock for the hydrocarbons associated with Fracture 1.

Following Thom and Spieker (1931), who discuss emplacement of calcite fractures and surface hydrocarbon seepage associated with gas migration during anticlinal uplift in the Teapot Dome field and Schoell and Beeunas (1996), who describe episodic gas migration in oil and gas fields as ubiquitous, more detailed study of the calcite and biomarker studies of the surface hydrocarbons might help identify the timing of the hydrocarbon emplacement in these fractures.

\section{Conclusions and suggestions for further work}

Whole oil gas chromatography of oil samples indicates two different types of oil in the Teapot Dome field, Cretaceous and Pennsylvanian. This is consistent with observations dating back to at least 1911. Oils from the Upper Cretaceous reservoirs, the Shannon Sandstone and the Wall Creek "Sands" show varying degrees of biodegradation, and alteration associated with numerous experiments, gas production and attempts at enhanced oil recovery over a period of almost 100 years. The alteration is also associated with trends related to the north-south structure of the oil field, with the most obviously altered samples occuring in northern most wells. Biomarker analyses of these oils will help to further elucidate the processes which are taking place in the reservoirs at the Teapot Dome field, as well as systematic sampling of the reservoirs, to include samples from the Shannon Sandstone reservoir in the northern dome of the field.

Molecular and isotopic analyses of a limited number of gas samples indicate alteration trends consistent with those seen in the oils (a north-south trend, with the most altered in the northern part of the dome). Two different processes, primary methanogenesis, and secondary bacterial alteration seem to be indicated. Systematic sampling of gas from the Teapot Dome field, with respect to the ongoing gas injection experiment, and compound specific isotope analyses of the gases might help to clearly describe processes in specific reservoirs.

There are two different types of hydrocarbon surface samples, with possibly two different sources. More detailed study of the calcite fractures and biomarker studies of the surface 
hydrocarbons might help identify the timing of the hydrocarbon emplacement in surface fractures in the Teapot Dome field.

\section{Literature Cited}

Bargas, C.L., Montgomery, H.D., Sharp, D. H., and Voslka, J.L., 1992, Immisicible CO2 Process for the Salt Creek Field: Society of Petroleum Engineers Reservoir Evaluation \& Engineering SPE21577.

Burtner, R.L., and Warner, M.A., 1984, Hydrocarbon generation in Lower Cretaceous Mowry and Skull Creek Shales of the northern Rocky Mountain Region, Hydrocarbon Source Rocks of the greater Rocky Mountain Region, Rocky Mountain Association of Geologists, p. 449-467.

Chung, H.M., Gormly, J.R., and Squires, R.M., 1988, Origin of Gaseous Hydrocarbons in Subsurface Environments: Theoretical Considerations of Carbon Isotope Distribution: Chemical Geology, v. 71, p. 97-103.

Connan, J., 1984, Biodegradation of Crude Oils in Reservoirs, in Brooks, J., Welte, Dietrich, ed., Advances in Petroleum Geochemistry: New York, Academic Press, p. 299-335.

Curry Jr., W.H., 1977, Teapot Dome, Past, Present and Future: The American Association of Petroleum Geologists Bulletin, v. 61, p. 671-697.

Dolton, G.E., and Fox, James, E., 1996, Powder River Basin Province (033), in Gautier, D.L., Dolton, G.L., Takahashi, K.I., and Varnes, K.L., ed., 1995 National assessment of United States oil and gas resources--Results, methodology and supporting data, U.S. Geological Survey Digital Data Series DDS-30, release 2, one CD-ROM.

Doyle, D.H., 1998, Low Cost Refracturing: Rock Creek Enterprises RMOTC Test Report 96PT14.

Horn, G.H., 1959, Geologic and Structure Map of Teapot Dome and Vicinity, Natrona County, Wyoming: U.S. Geological Survey OFR 59-57.

Hunt, J.M., 1953, Composition of crude oil and its relation to stratigraphy in Wyoming: The American Association of Petroleum Geologists Bulletin, v. 37, no. 8, p. 1837-1872.

----------, 1996, Petroleum Geochemistry and Geology (Second Edition ed.): New York, W. H. Freeman and Company.

Knight, W.C., and Slosson, E.E., 1896, The Petroleum of Salt Creek, Wyoming: University of Wyoming School of Mines Petroleum Series Bulletin, v. 1, p. 47.

Leach Jr., W.H., 2003, CO2 Flooding: Oil and Gas Investor (November), v. 23, no. 11.

Martini, A.M., Walter, L. M., Ku, T. C. W., Budai, J. M., McIntosh, J.C., and Schoell, M., 2003, Microbial production and modification of gases in sedimentary basins: A geochemical case study from a Devonian shale gas play, Michigan basin: The American Association of Petroleum Geologists Bulletin, v. 87, no. 8, p. 1355-1375.

Mauk, J.L., and Burruss, R.C., 2002, Water washing of Proterozoic oil in the Midcontinent rift system: The American Association of Petroleum Geologists Bulletin, v. 86, no. 6, p. 1113-1127.

Momper, J.A., and Williams, J.A., 1984, Geochemical Exploration in the Powder River basin, in Demaison, G., and Murris, R.J., ed., Petroleum Geochemistry and Basin Evaluation, The American Association of Petroleum Geologists Memoir, p. 181-191.

Olsen, D.K., Sarathi, P.S., Hendricks, M.L., Schulte, R.K., and Giangiacomo, L.A., 1993, Case of Steam Injection Operations at Naval Petroleum Reserve No. 3, Teapot Dome Field, Wyoming: A Shallow Heterogeneous Light-Oil Reservoir: Society of Petroleum Engineers SPE 25786.

Opsal, C.M., 1997, RMOTC Tests New Tools and Techniques for the Oil Industry: Society of Petroleum Engineers SPE 38349. 
Orr, F.M., 2004, SPE 88842 Storage of Carbon Dioxide in Geologic Formations: Society of Petroleum Engineers Distinguished Author Series September, p. 90-97.

Schoell, M., and Beeunas, M.A., 1996, Episodic Migration of Natural Gas: A Worldwide Phenomenon of Dynamic Filling of Oil and Gas Field ABSTRACT, in American Association of Petroleum Geologists Annual Convention, San Diego, CA, p. 126.

Shanmugam, G., 1985, Significance of Coniferous Rain Forests and Related Organic Matter in Generating Commercial Quantities of Oil, Gippsland Basin, Australia: The American Association of Petroleum Geologists Bulletin, v. 69, no. 8, p. 1241-1254.

Sheldon, R.P., 1967, Long Distance Migration of Oil in Wyoming: Mountain Geologist, v. 4, p. 53-65.

Stabler, H., 1931, Waters of the Salt Creek-Teapot Dome uplift: U.S.Geological Survey Professional Paper 163.

Strickland, J.W., 1958, Habitat of Oil in the Powder River Basin: Wyoming Geological 13th Annual Field Conference Guidebook, p. 132-147.

Thom Jr., W.T., and Spieker, Edmund M., 1931, The Significance of Geologic Conditions in Naval Petroleum Reserve No. 3, Wyoming: U.S.Geological Survey Professional Paper 163 , p. 64 pp.

Thompson, K.F.M., 1982, Classification and thermal history of petroleum based on light hydrocarbons: Geochemica et Cosmochimica Acta, v. 47, p. 303-316. , 1987, Fractionated aromatic petroleums and the generation of gascondensates: Organic Geochemistry, v. 11, no. no. 6, p. 573-590.

U.S. Geological Survey, 2004, Powder River Basin interactive map: U.S. Geological Survey web site at http://energy.cr.usgs.gov/oilgas/noga (accessed July 2005).

Wegemann, C.H., 1911, The Salt Creek Oil field, Wyoming: U.S.Geological Survey Bulletin 452 , p. 37-87. 670, p. 52 pp.

Wenger, W.J., and Reid, B. W., 1958, Characteristics of Petroleum in the Powder River Basin: Wyoming Geological 13th Annual Field Conference Guidebook, p. 148-156.

Wenger, L.M., Davis, C. L., and Isaksen, G. H., 2002, Multiple Controls on Petroleum Biodegradation and Impact on Oil Quality: Society of Petroleum Engineers Reservoir Evaluation \& Engineering SPE 80168.

Whiticar, M.J., 1996, Stable isotope geochemistry of coals, humic kerogens and related natural gases: International Journal of Coal Geology, v. 32, p. 191-215.

Whiticar, M.J., 1999, Carbon and hydrogen isotope systematics of bacterial formation and oxidation of methane: Chemical Geology, v. 161, no. 1-3, p. 291-314.

\section{Acknowledgements}

Vicki Stamp and Mark Milliken of RMOTC arranged for access to Teapot Dome field, to equipment and to data necessary for this study. Field sampling of oils and gases was kindly and patiently provided by Dan Kelly and Steve Hardy of RMOTC. Anadarko Petroleum Corporation kindly provided access to the Salt Creek oil field and provided oil samples. Sean Brennan helped with oil sampling. Steve Hardy provided additional historical data on wells in the Teapot Dome field. Suggestions and comments from Bob Ryder and Dan Hayba greatly improved the manuscript. 


\section{Study Area}

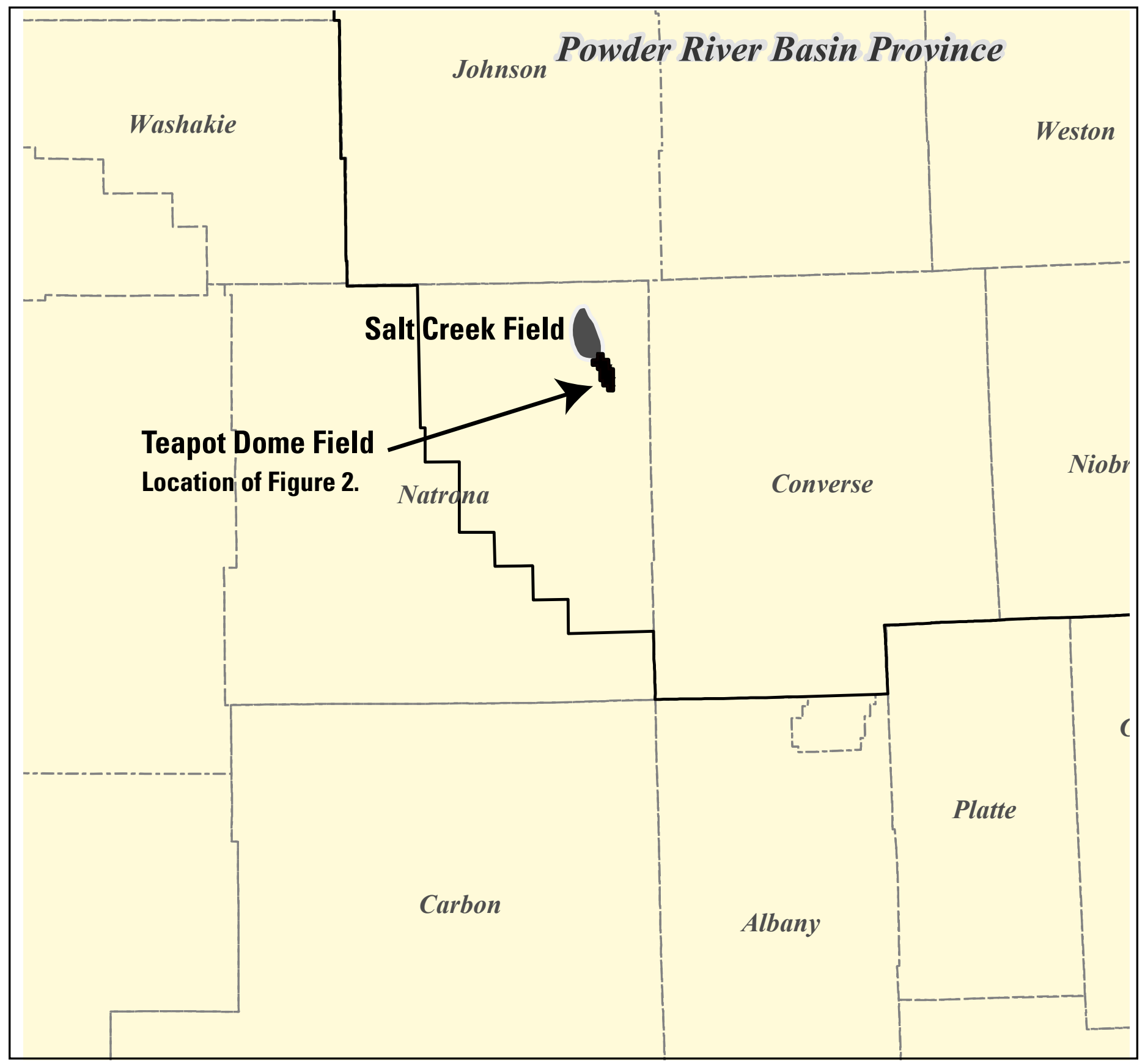

Figure 1. Map shows the Teapot Dome field and adjacent Salt Creek field on the western margin of the Powder River Basin in Natrona County, Wyoming (After Dolton and Fox, 1996; USGS Powder River Basin interactive map, 2004).

Scale

1:1,719,714

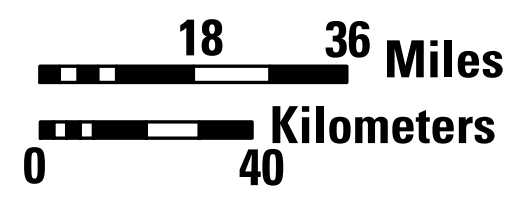

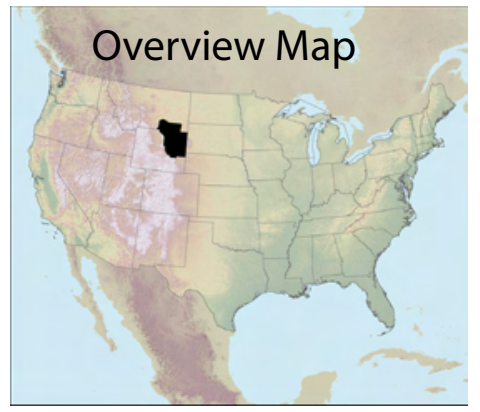




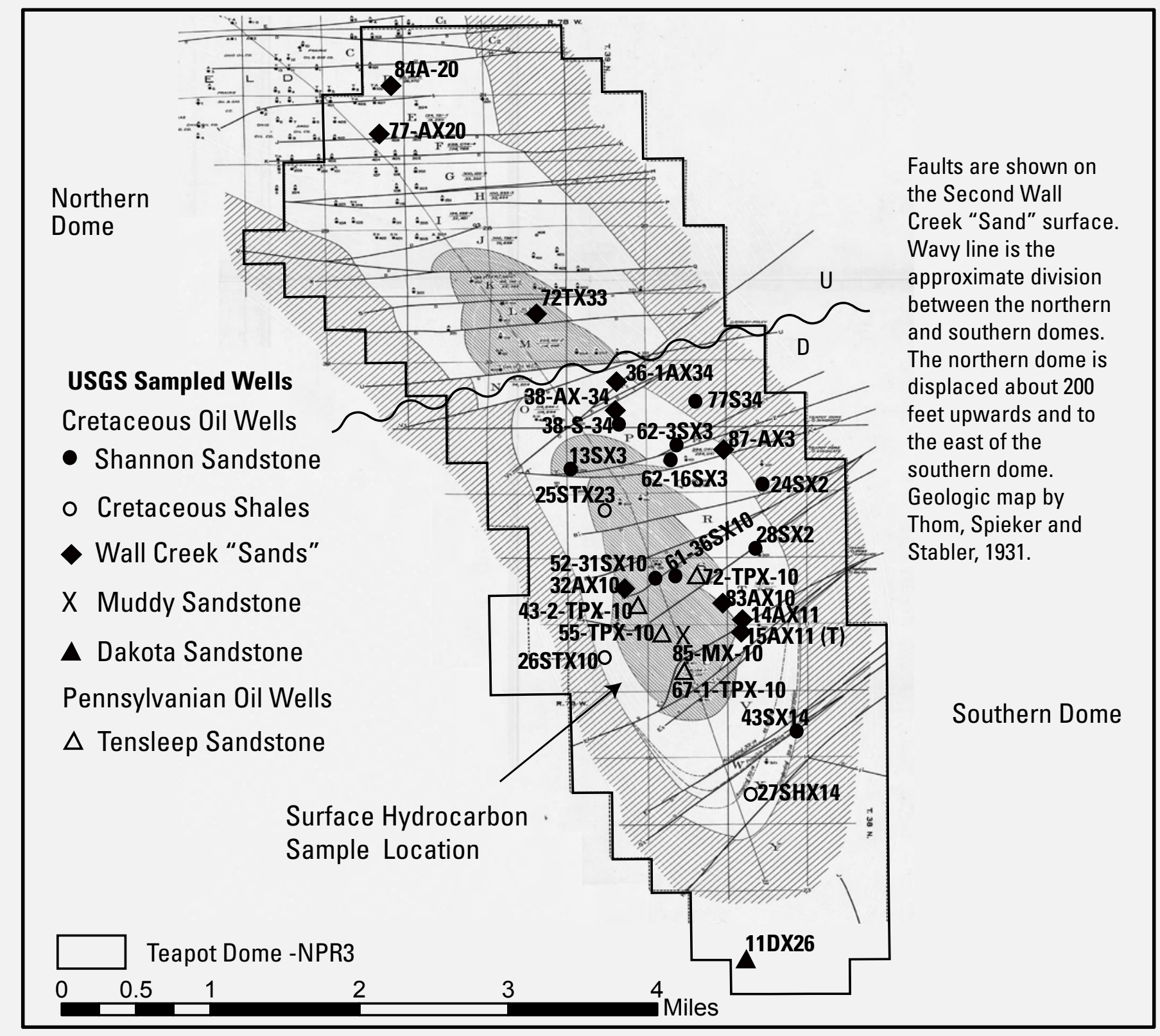

Figure 2. Map of sample locations in the Teapot Dome field. 


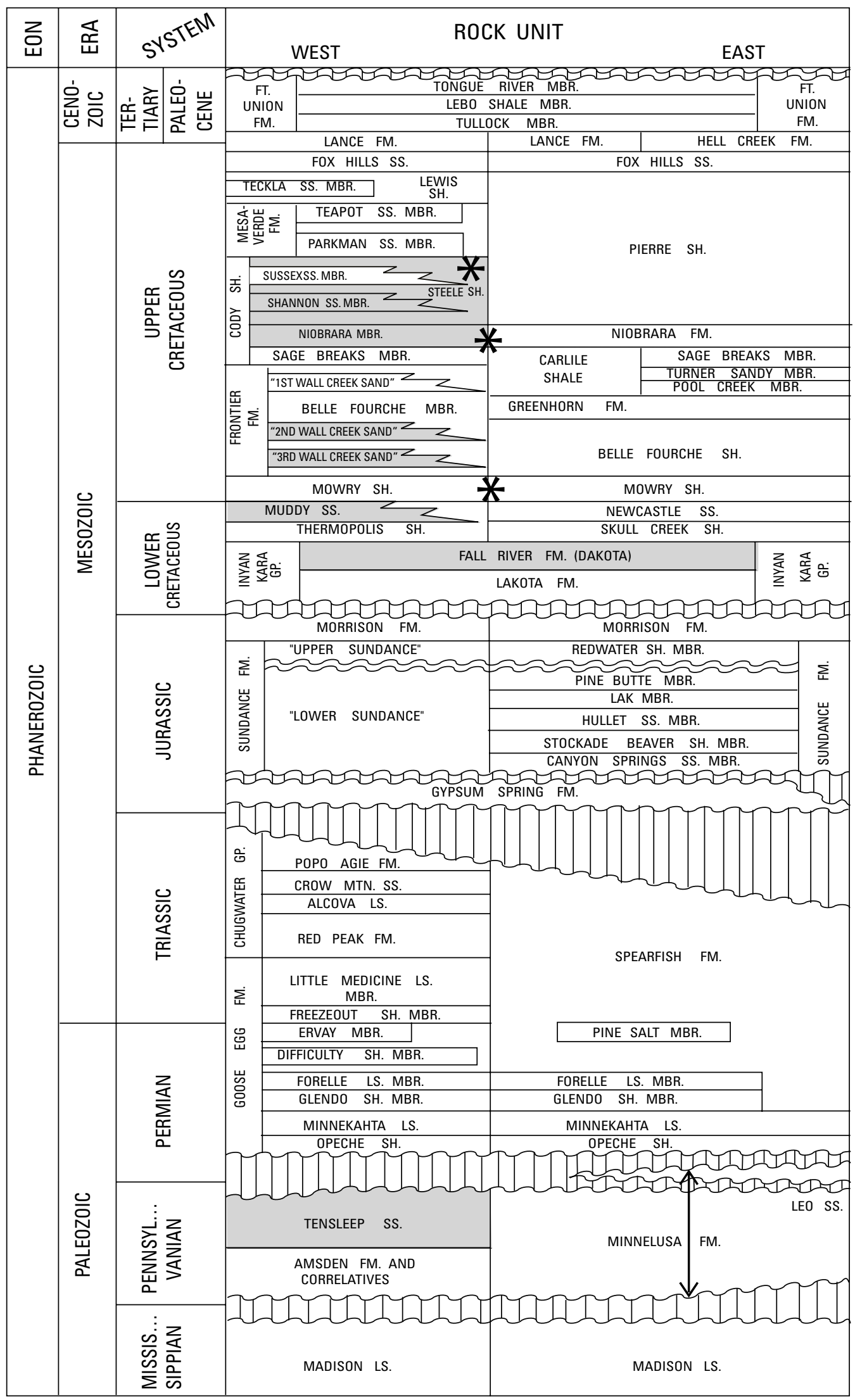

Sampled

Units

Samples for this study were taken from the Shannon Sandstone, the Steele Shale and the Niobrara Member of the Cody Shale Formation, the Second and Third Wall Creek "Sands", the Muddy Sandstone (gas sample only), the Dakota Sandstone, and the Tensleep Sandstone. These units are the only ones currently producing in the Teapot Dome field. (RMOTC, 2005.)

\section{* Hydrocarbon source rocks}

The Mowry Shale is thought to be the major source rock for the Cretaceous reservoirs, with minor contributions from the Steele and Niobrara units. The source rock for the Tensleep Sandstone is thought to be the Phosphoria Formation, centered in Idaho. (Hunt, 1953; Sheldon, 1967: Momper and Williams, 1979)

Figure 3. Stratigraphic column of the Basin Margin Anticline Play of the Powder River Basin Province (after Dolton and Fox, 1996). The Teapot Dome field is on the western margin. The Wall Creek "Sands" were added after Horn, 1959. 


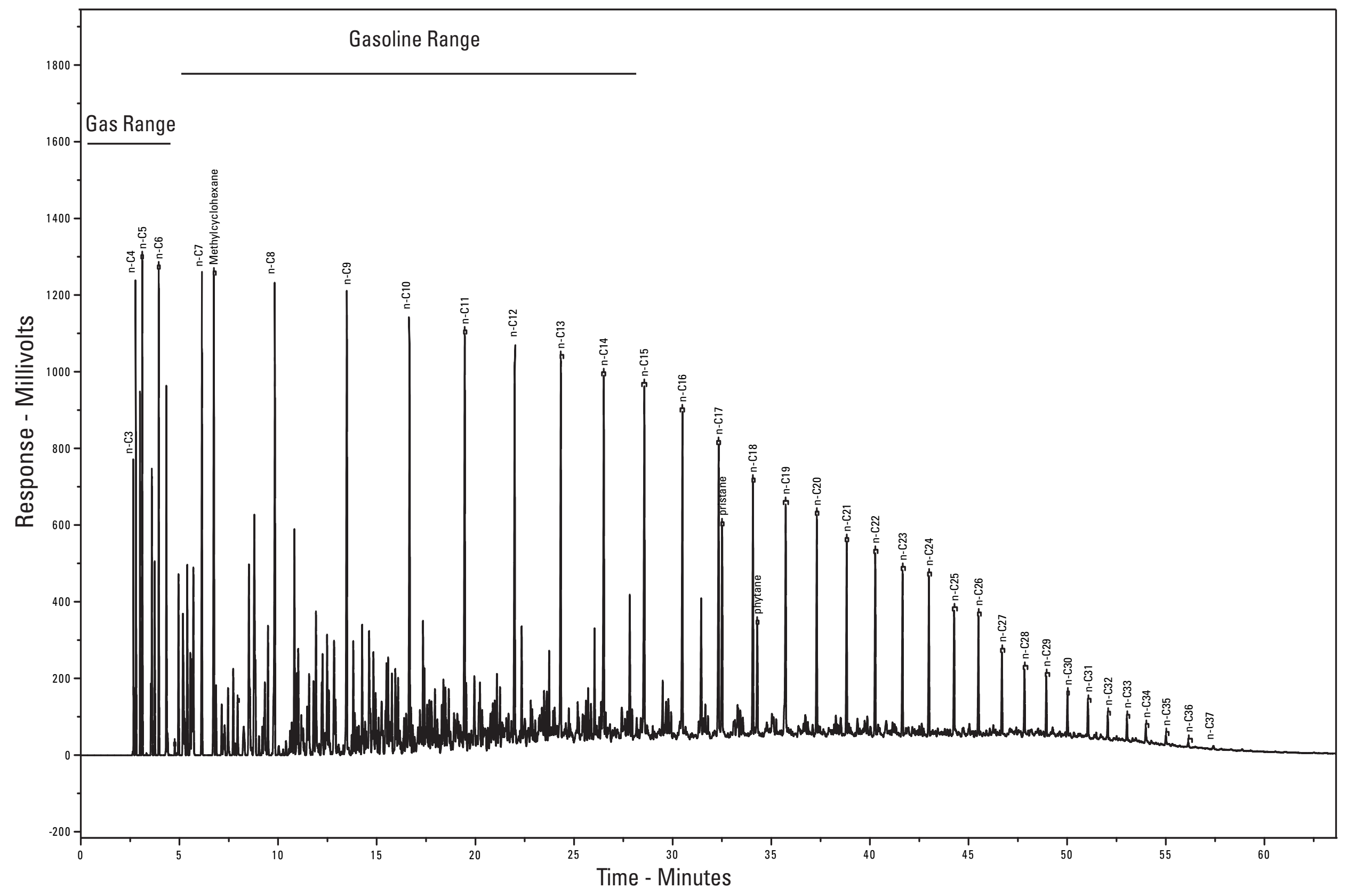

Figure 4a. A whole oil gas chromatogram of a typical, unaltered crude oil. It has a full complement of n-alkanes, tapering downards in height from the gas range to the heavier hydrocarbons. The lighter gases such as methane, $\mathrm{n}-\mathrm{C} 1$, and ethane, $\mathrm{n}-\mathrm{C2}$, frequently escape during sample collection and handling unless special methods are used. 


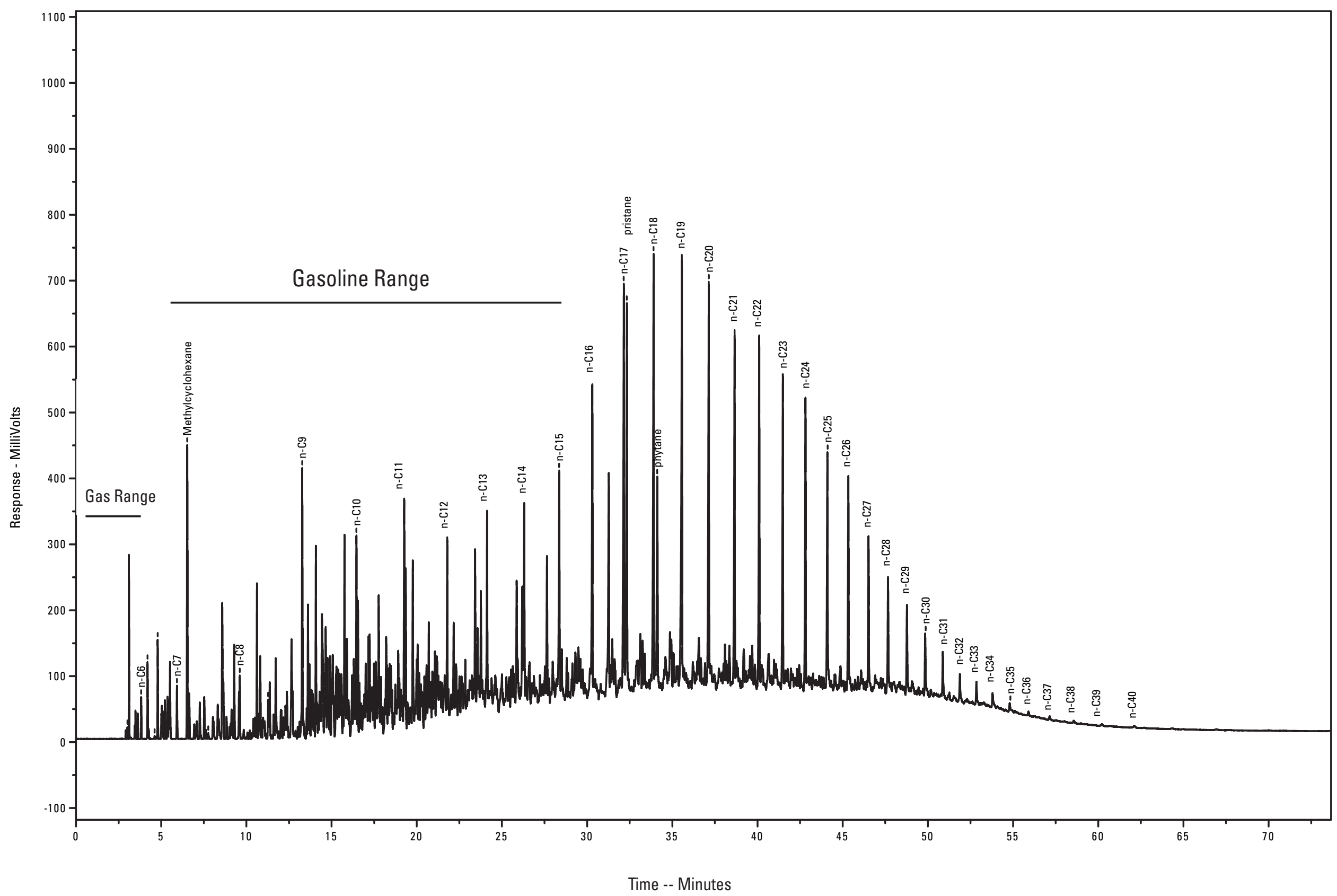

Figure 4b. A whole oil gas chromatogram of an altered crude oil. The diminished peak heights in the gas range and gasoline range peaks are indicative of secondary bacterial degradation. (Connan, 1984) 


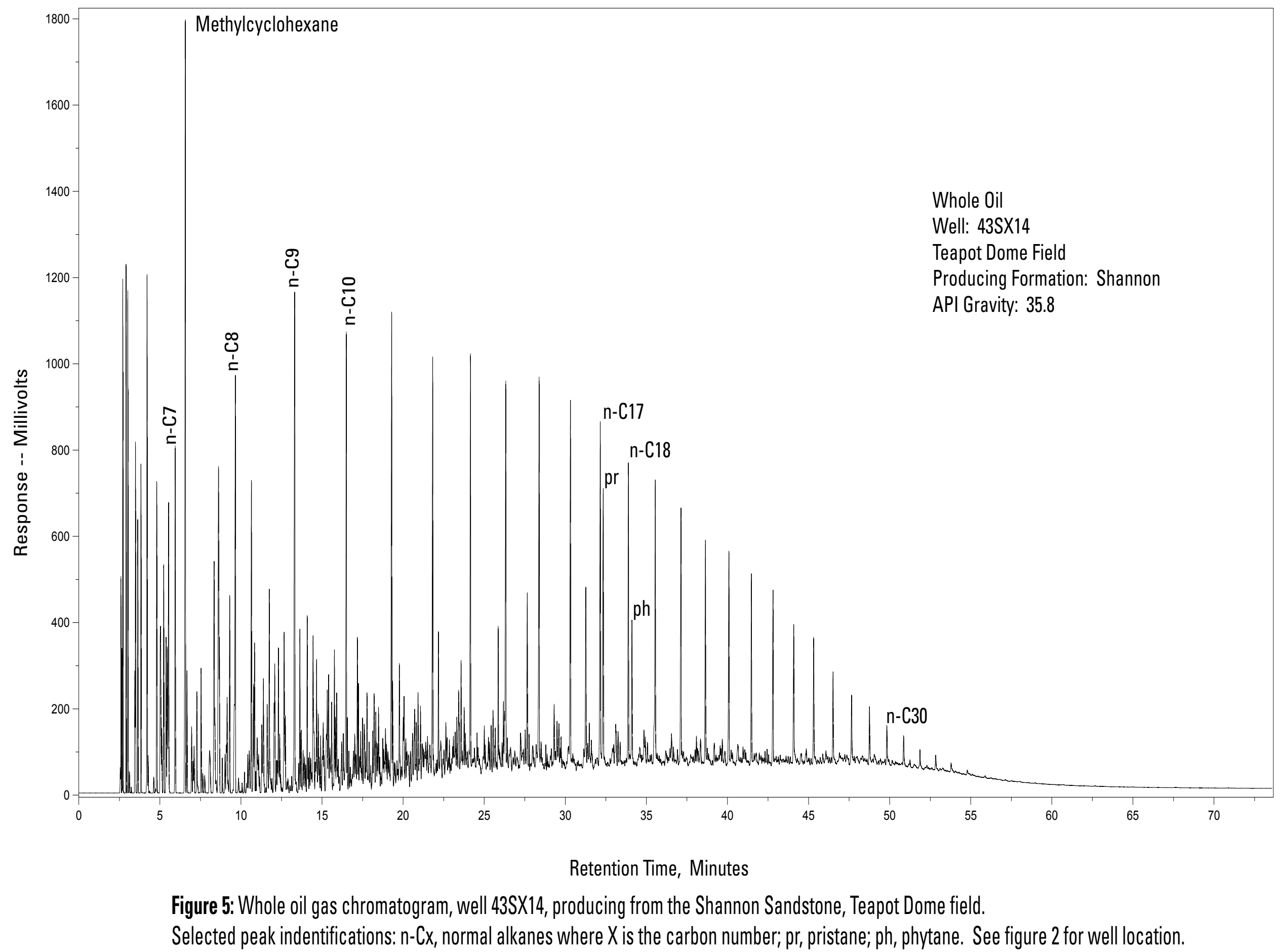




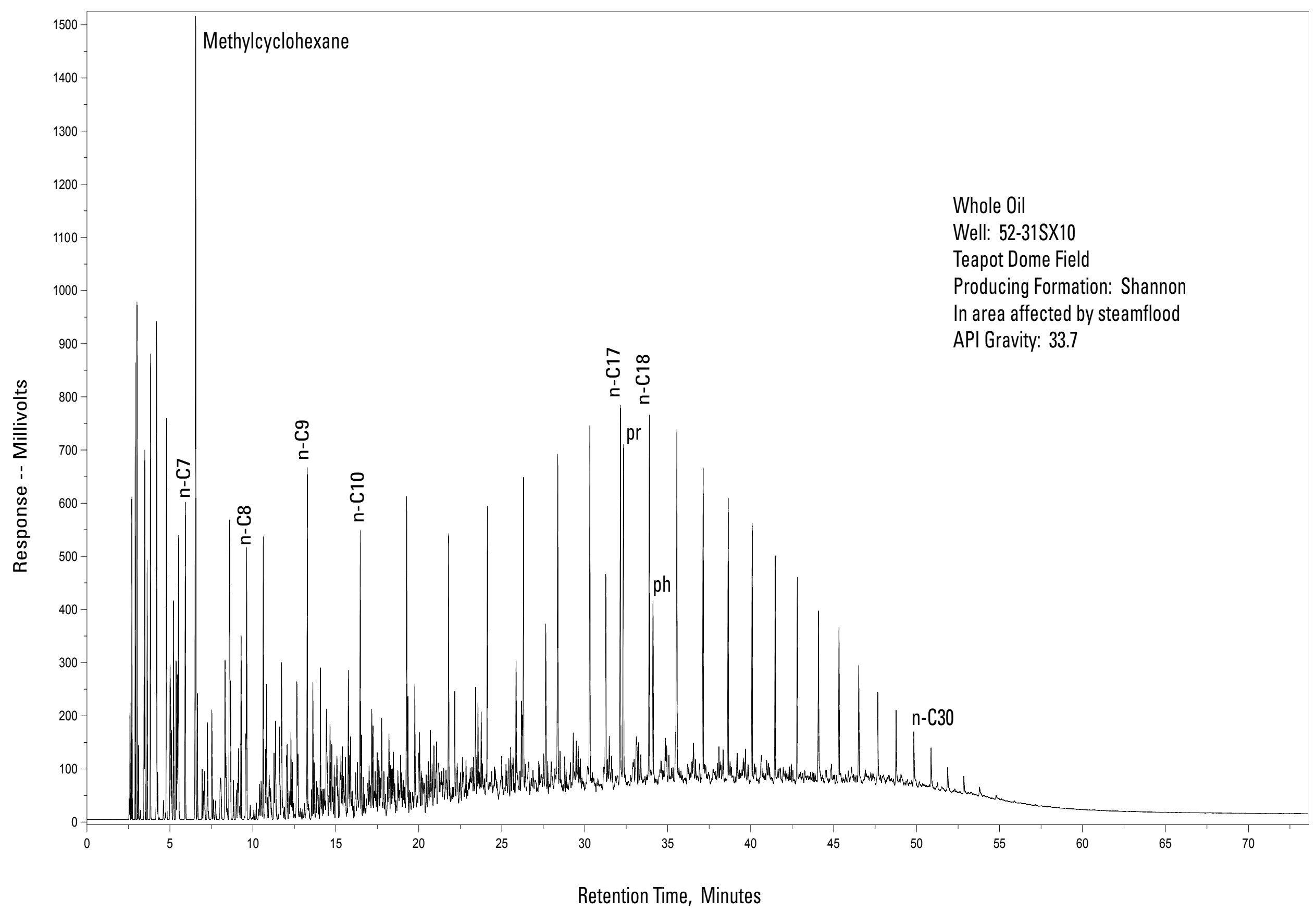

Figure 6: Whole oil gas chromatogram, well 52-31SX10, producing from the Shannon Sandstone, Teapot Dome field. Selected peak indentifications: $n-C x$, normal alkanes where $X$ is the carbon number; pr, pristane; ph, phytane. See figure 2 for well location. 


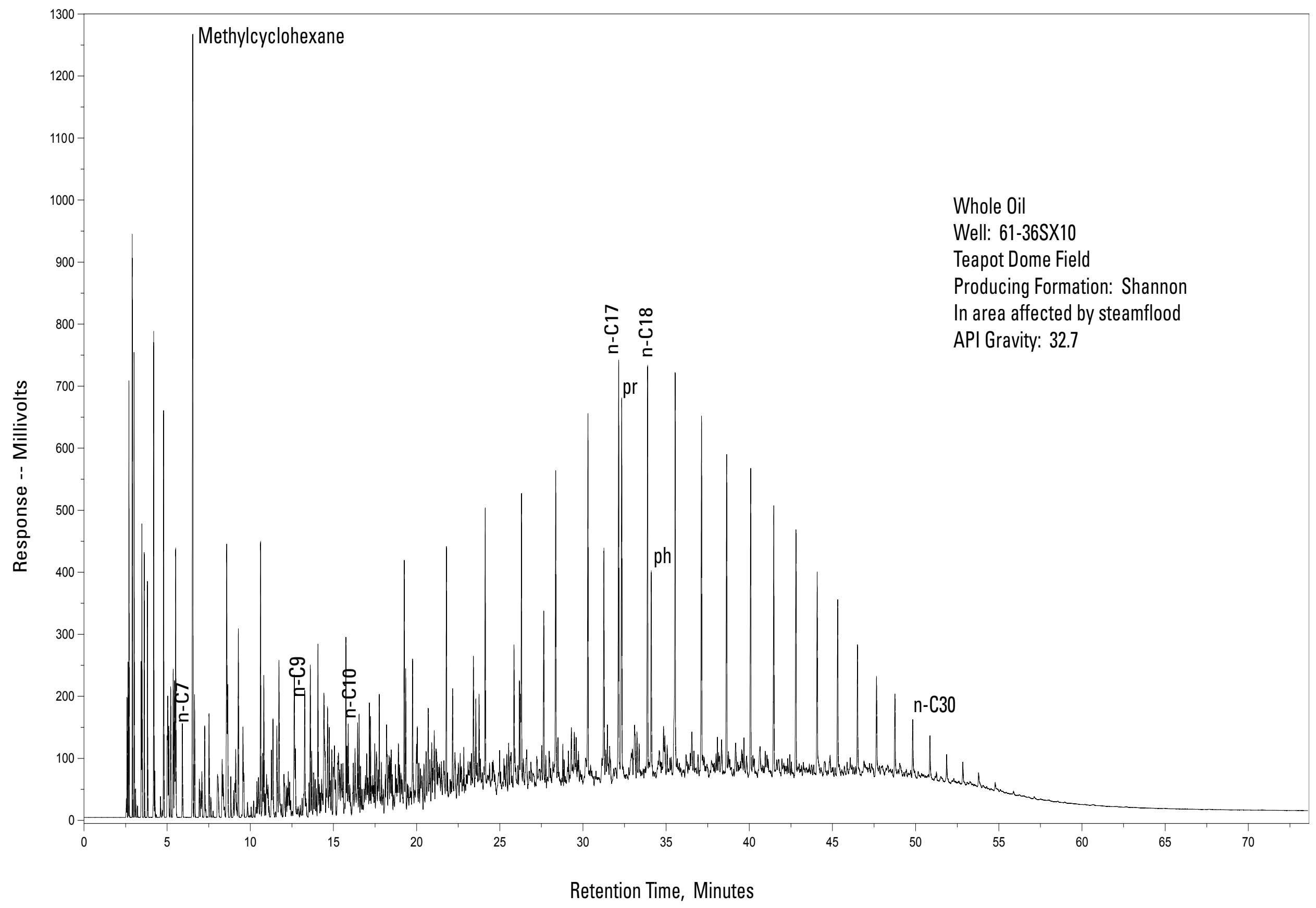

Figure 7: Whole oil gas chromatogram, well 61-36SX10, producing from the Shannon Sandstone, Teapot Dome field. Selected peak indentifications: $\mathrm{n}-\mathrm{Cx}$, normal alkanes where $\mathrm{X}$ is the carbon number; $\mathrm{pr}$, pristane; ph, phytane. 


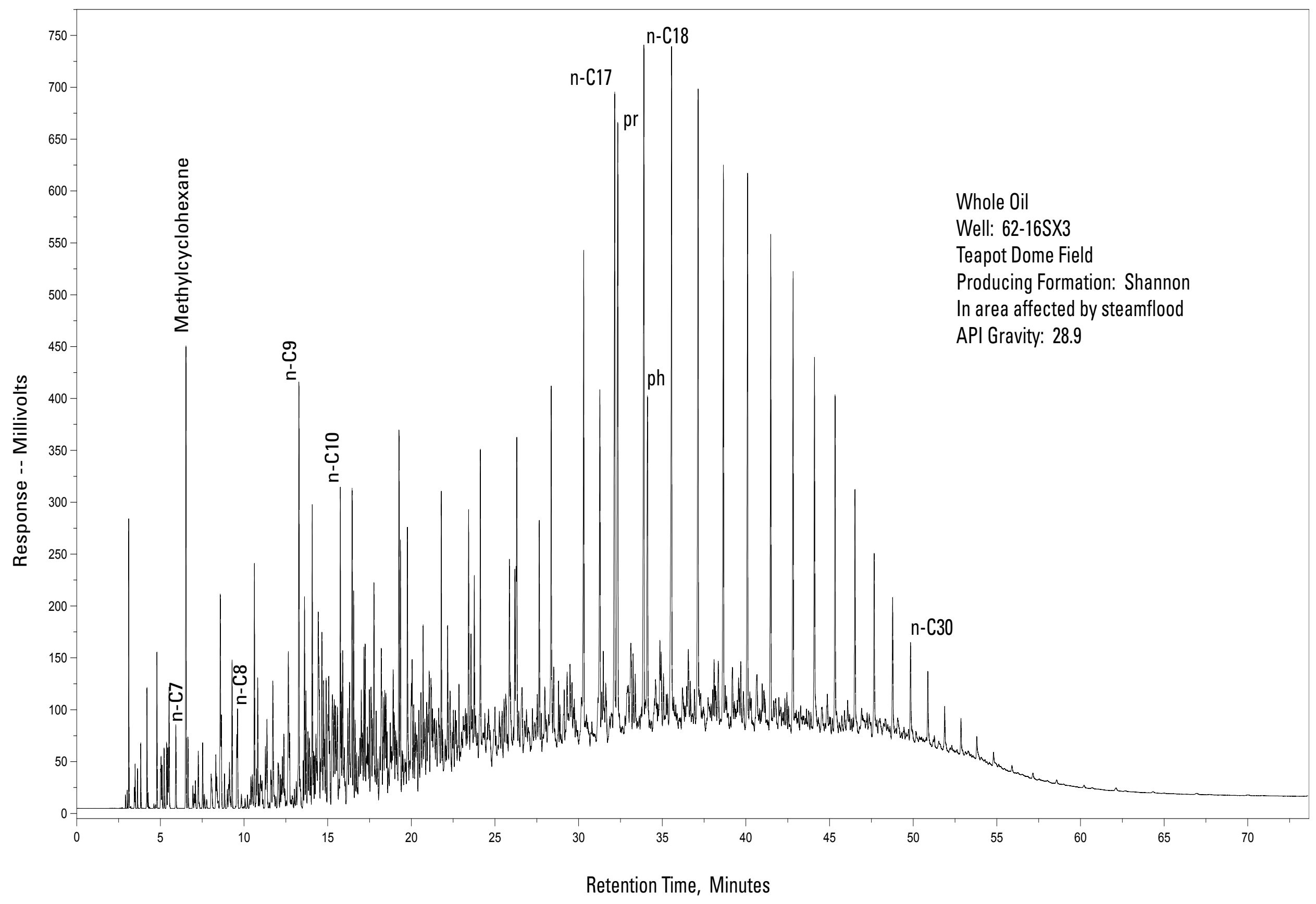

Figure 8: Whole oil gas chromatogram, well 62-16SX3, producing from the Shannon Sandstone, Teapot Dome field.

Selected peak indentifications: $n$ - $C x$, normal alkanes where $X$ is the carbon number; pr, pristane; ph, phytane. See figure 2 for well location. 


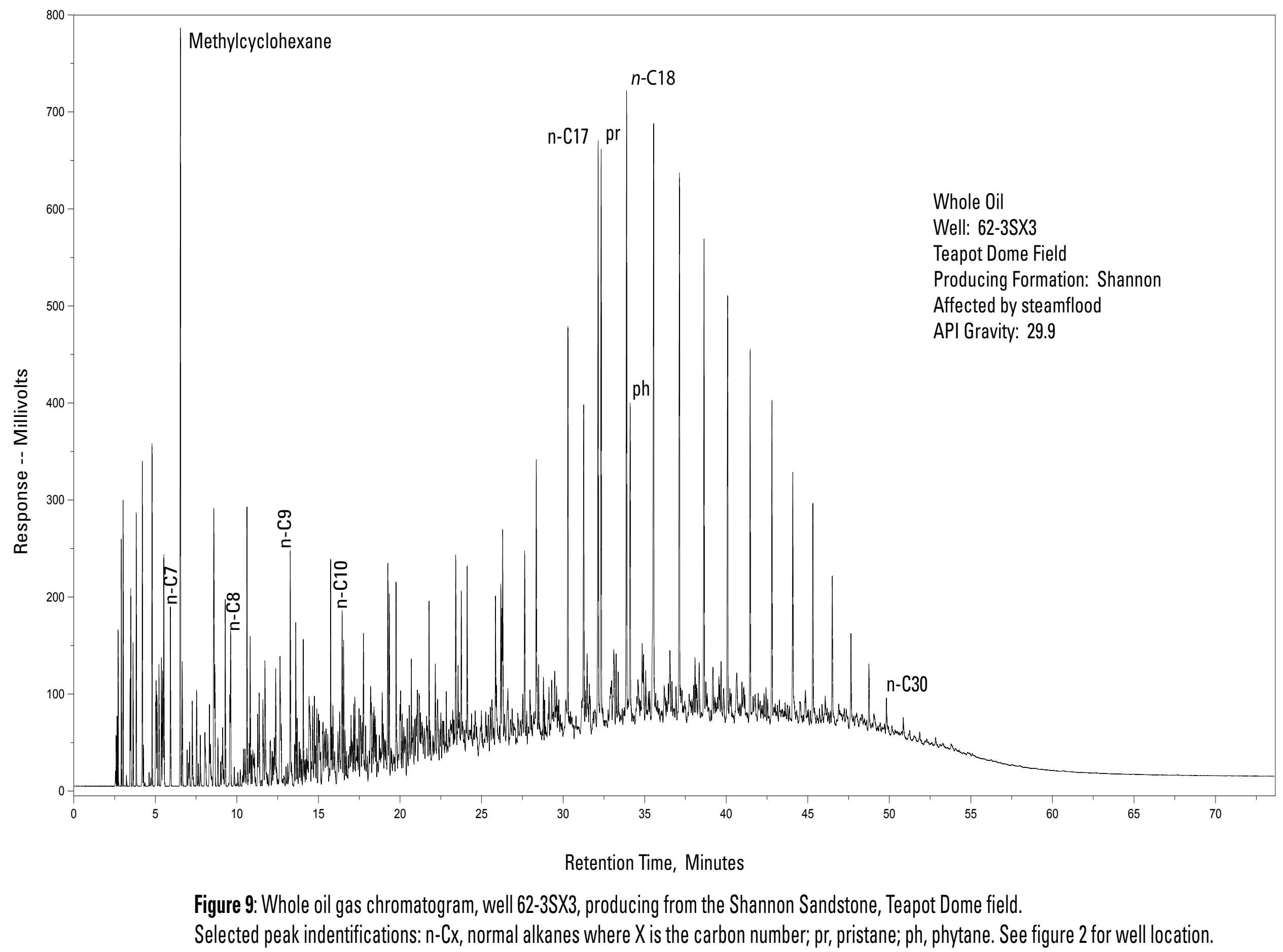




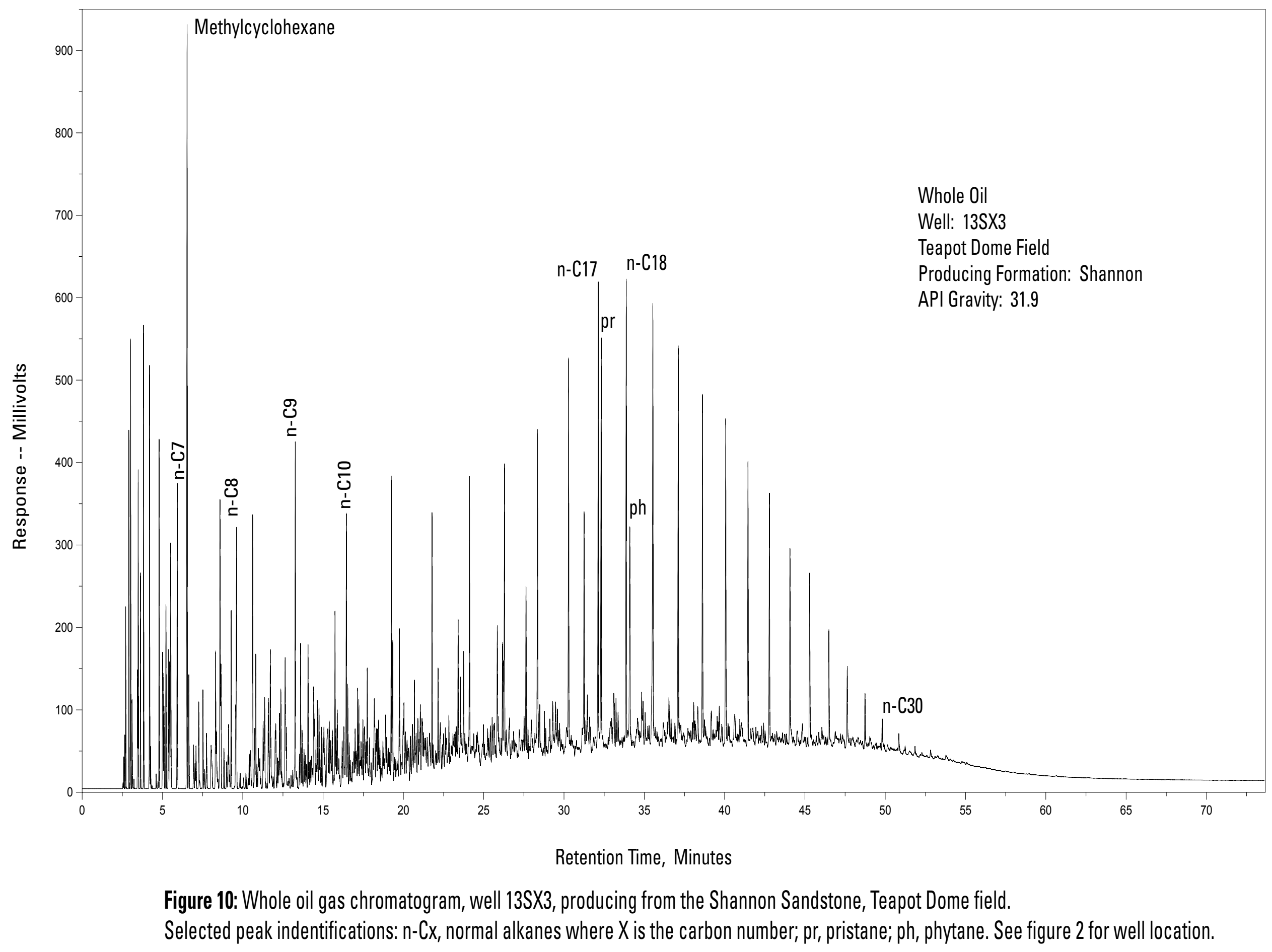




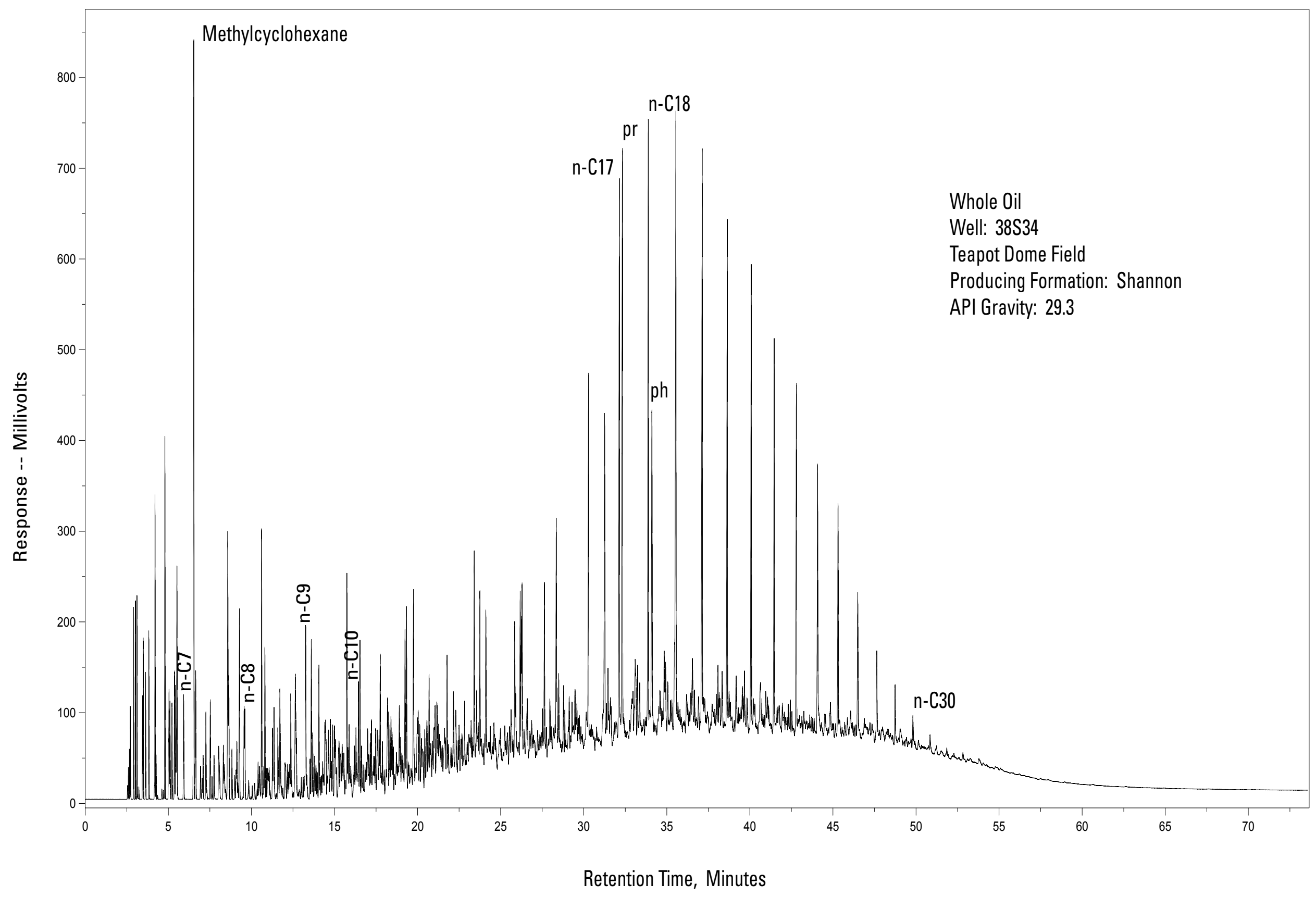

Figure 11: Whole oil gas chromatogram, well 38-S-34, producing from the Shannon Sandstone, Teapot Dome field.

Selected peak indentific ations: $\mathrm{n}$ - $\mathrm{CX}$, normal alkanes where $\mathrm{X}$ is the carbon number; pr, pristane; ph, phytane. See figure 2 for well location. 


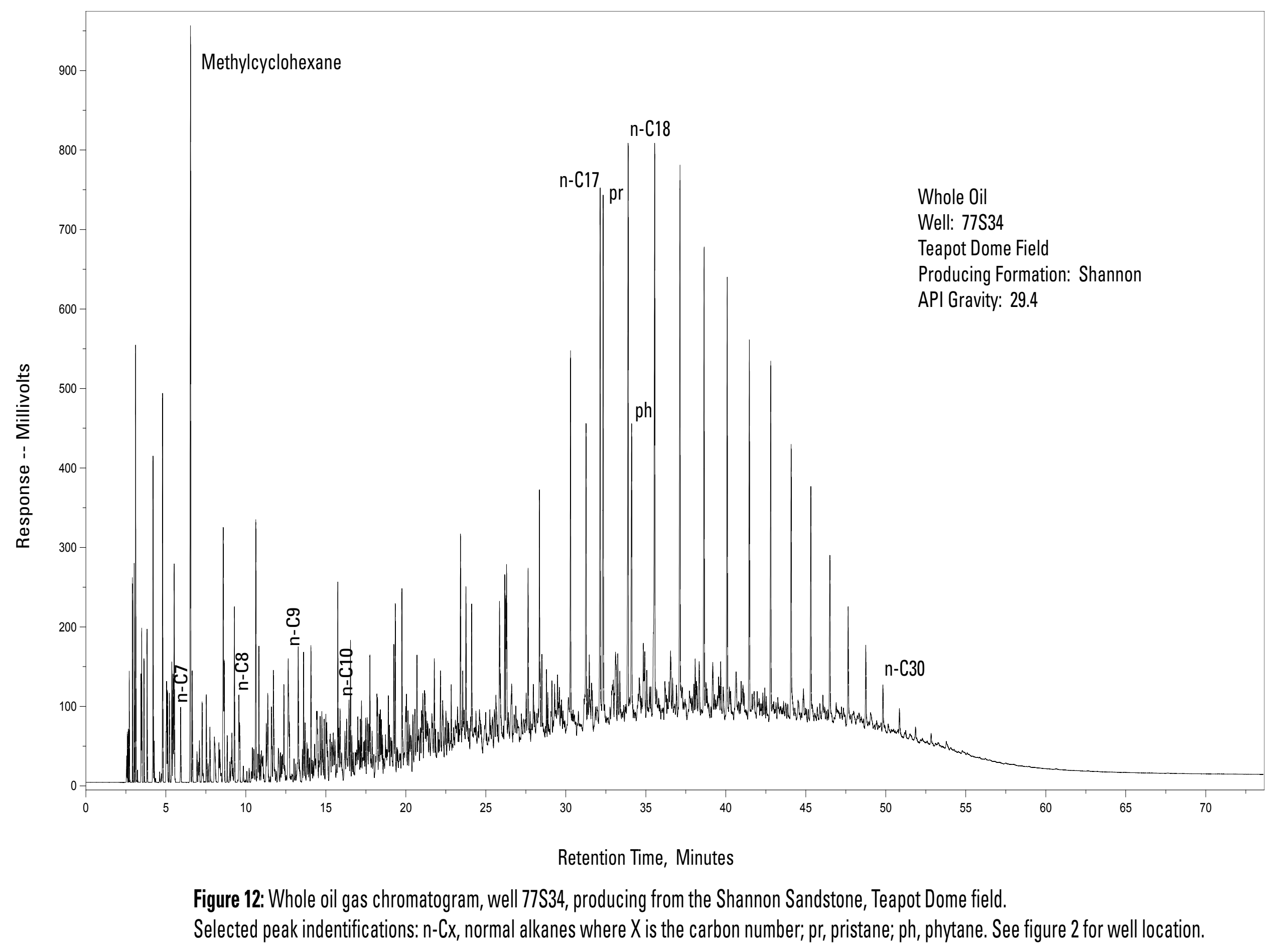




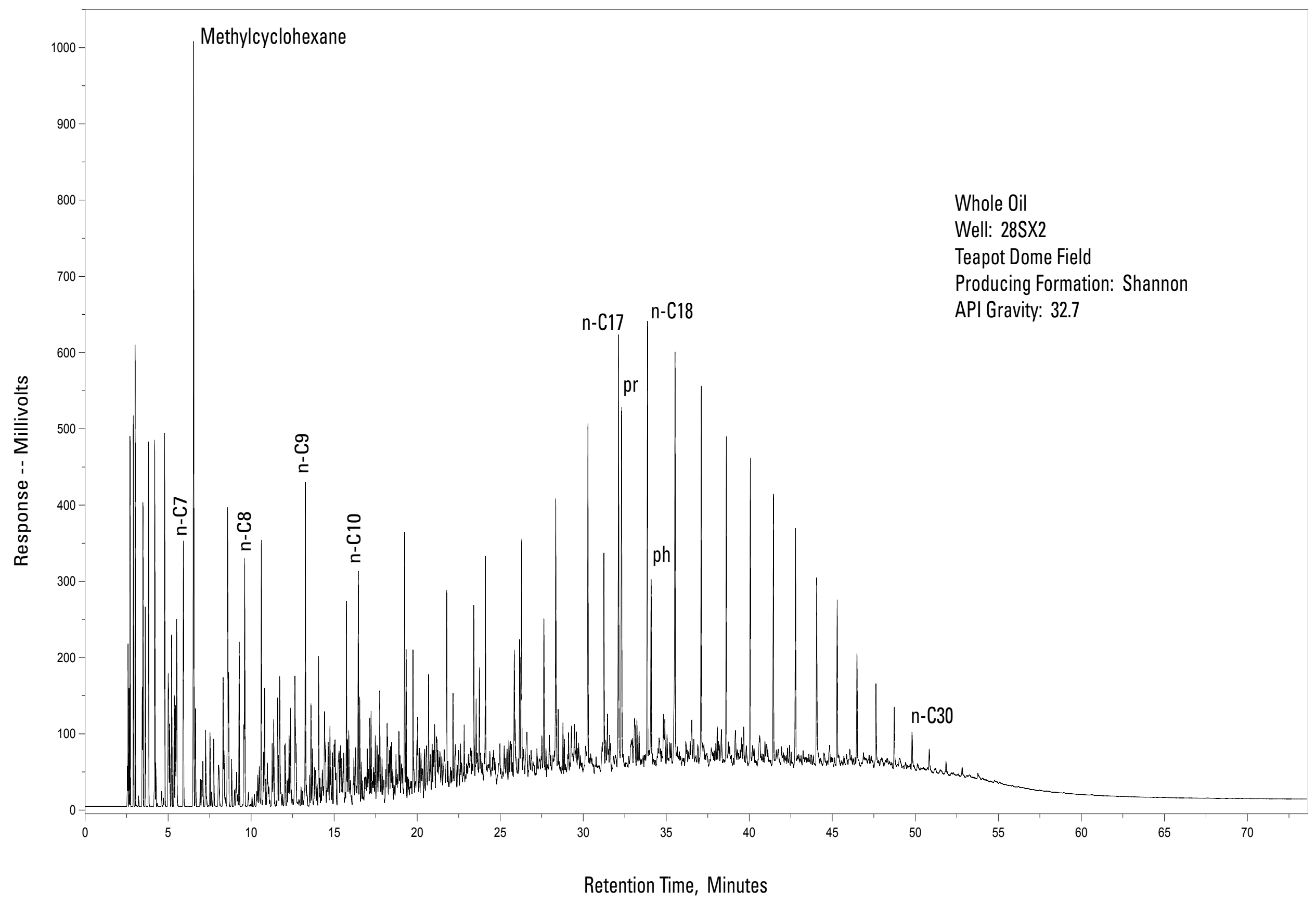

Figure 13: Whole oil gas chromatogram, well 28SX2, producing from the Shannon Sandstone, Teapot Dome field.

Selected peak indentifications: $n$ - $C x$, normal alkanes where $X$ is the carbon number; pr, pristane; ph, phytane. See figure 2 for well location. 


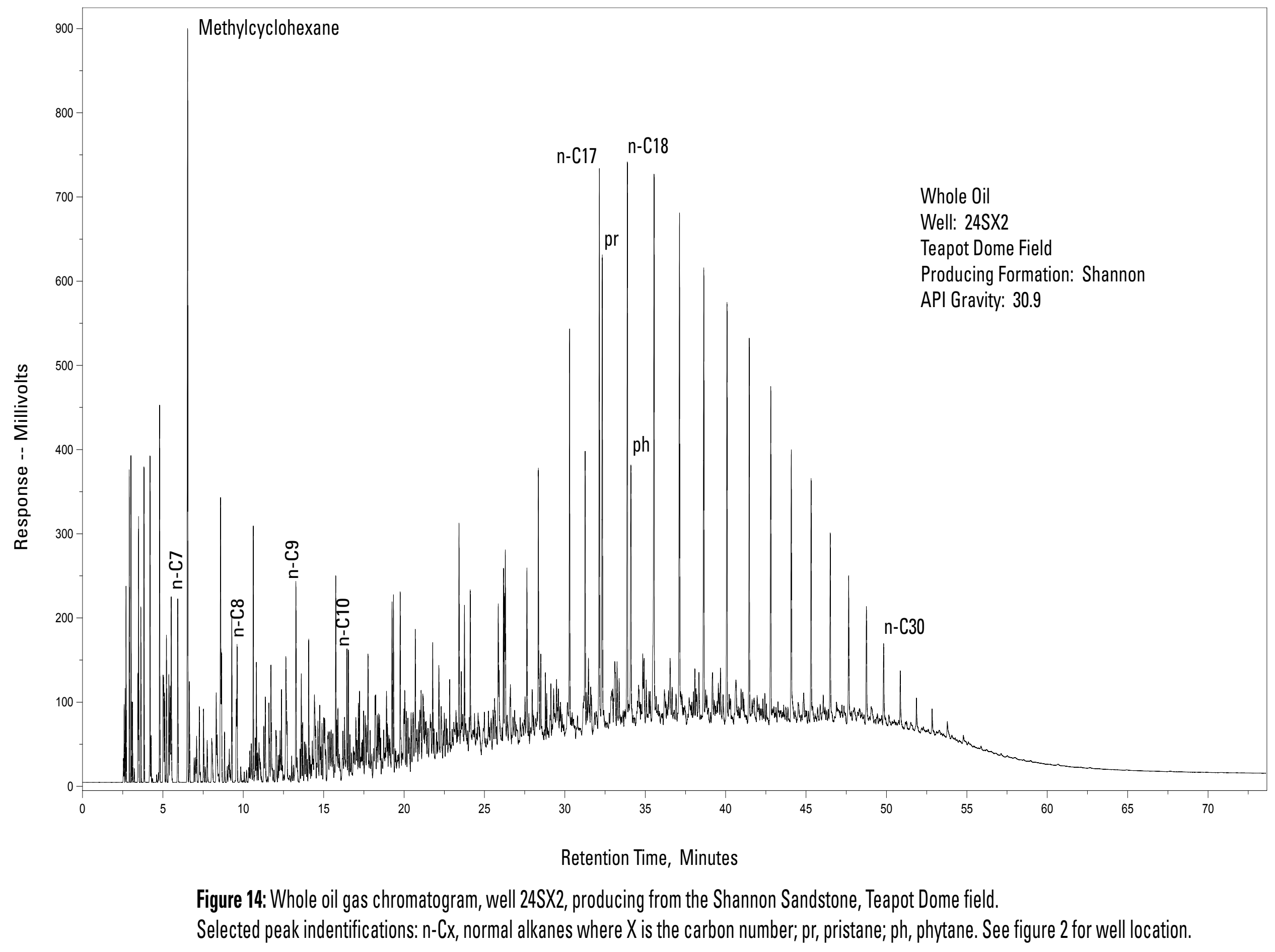




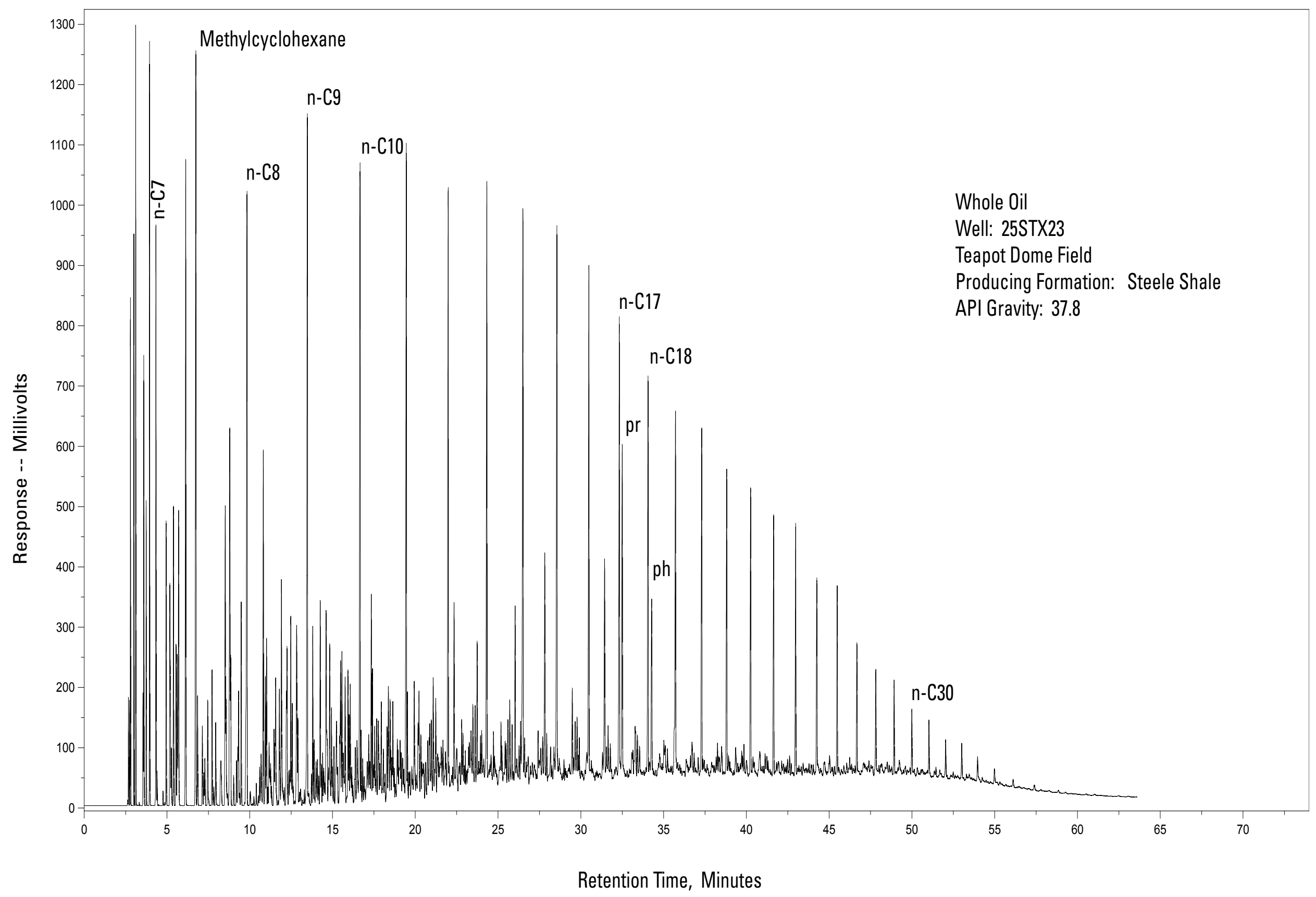

Figure 15: Whole oil gas chromatogram, well 25STX23, producing from the Steele Shale, Teapot Dome field.

Selected peak indentifications: $n-C x$, normal alkanes where $X$ is the carbon number; pr, pristane; ph, phytane. See figure 2 for well location. 


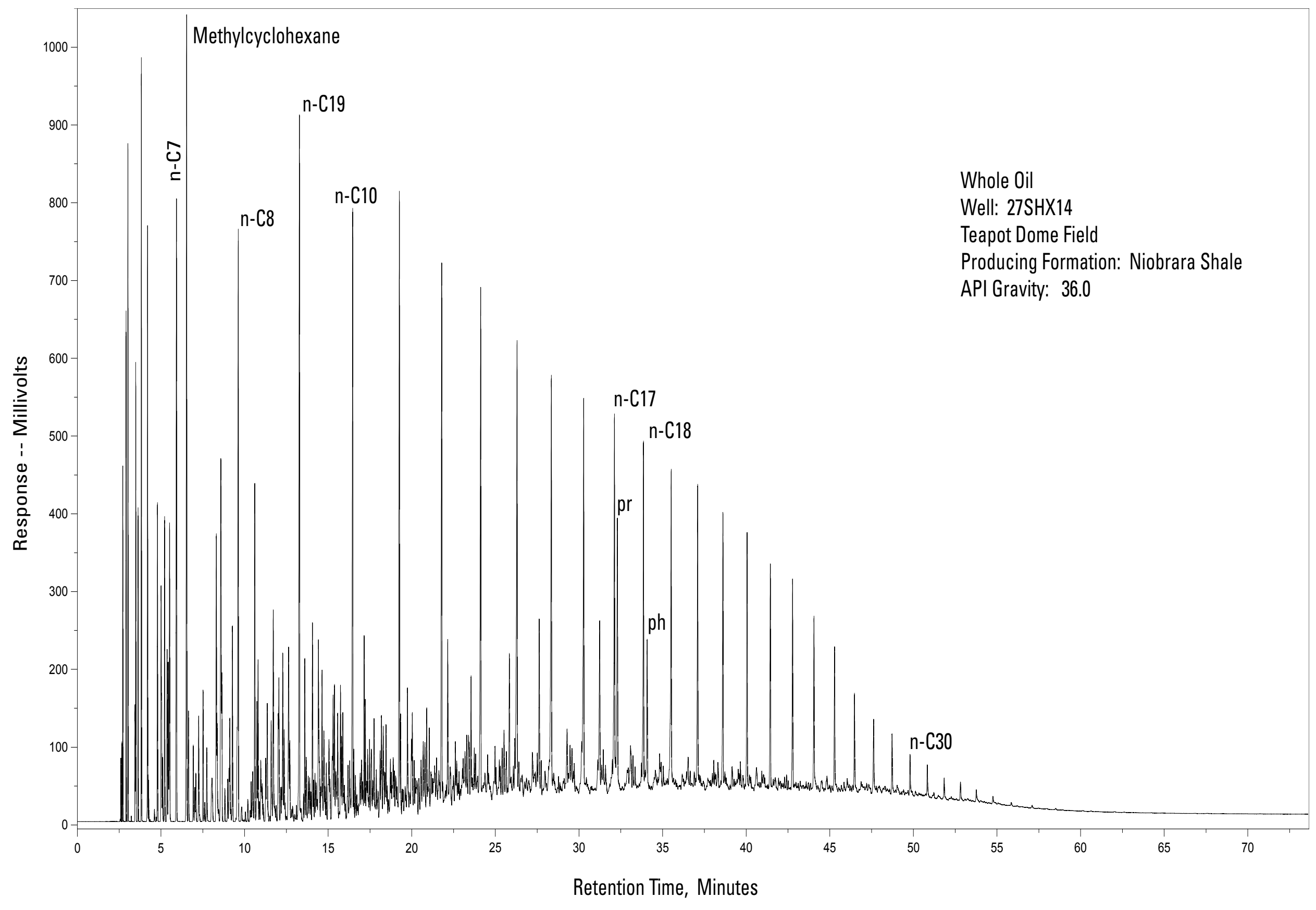

Figure 16: Whole oil gas chromatogram, well 27SHX14, producing from the Niobrara Shale, Teapot Dome field.

Selected peak indentifications: $n$ - $C x$, normal alkanes where $X$ is the carbon number; pr, pristane; ph, phytane. See figure 2 for well location. 


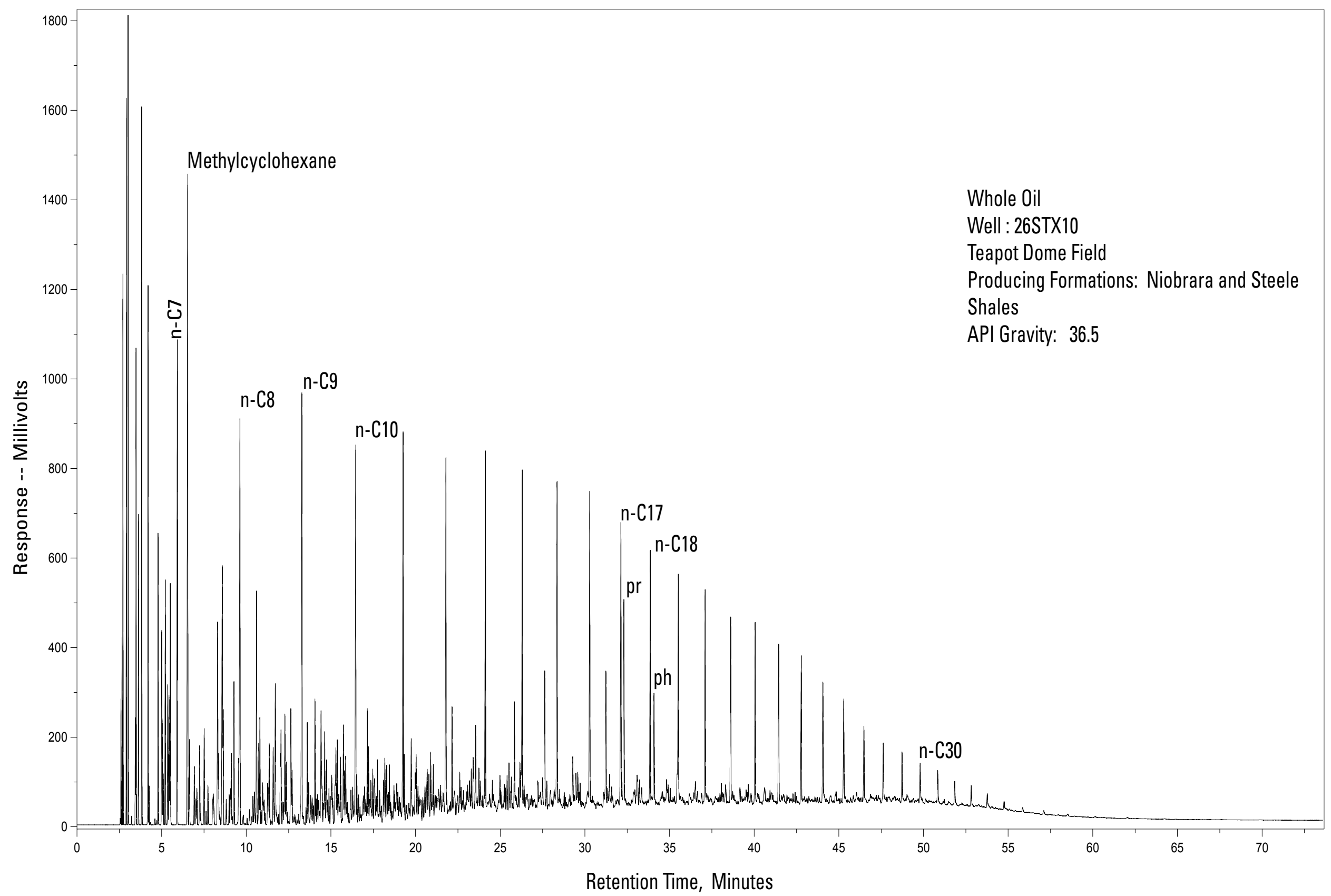

Figure 17: Whole oil gas chromatogram, well 26STX10, producing from the Niobrara and Steele Shales, Teapot Dome field. Selected peak indentifications: $n$ - $C x$, normal alkanes where $X$ is the carbon number; pr, pristane; ph, phytane. See figure 2 for well location. 


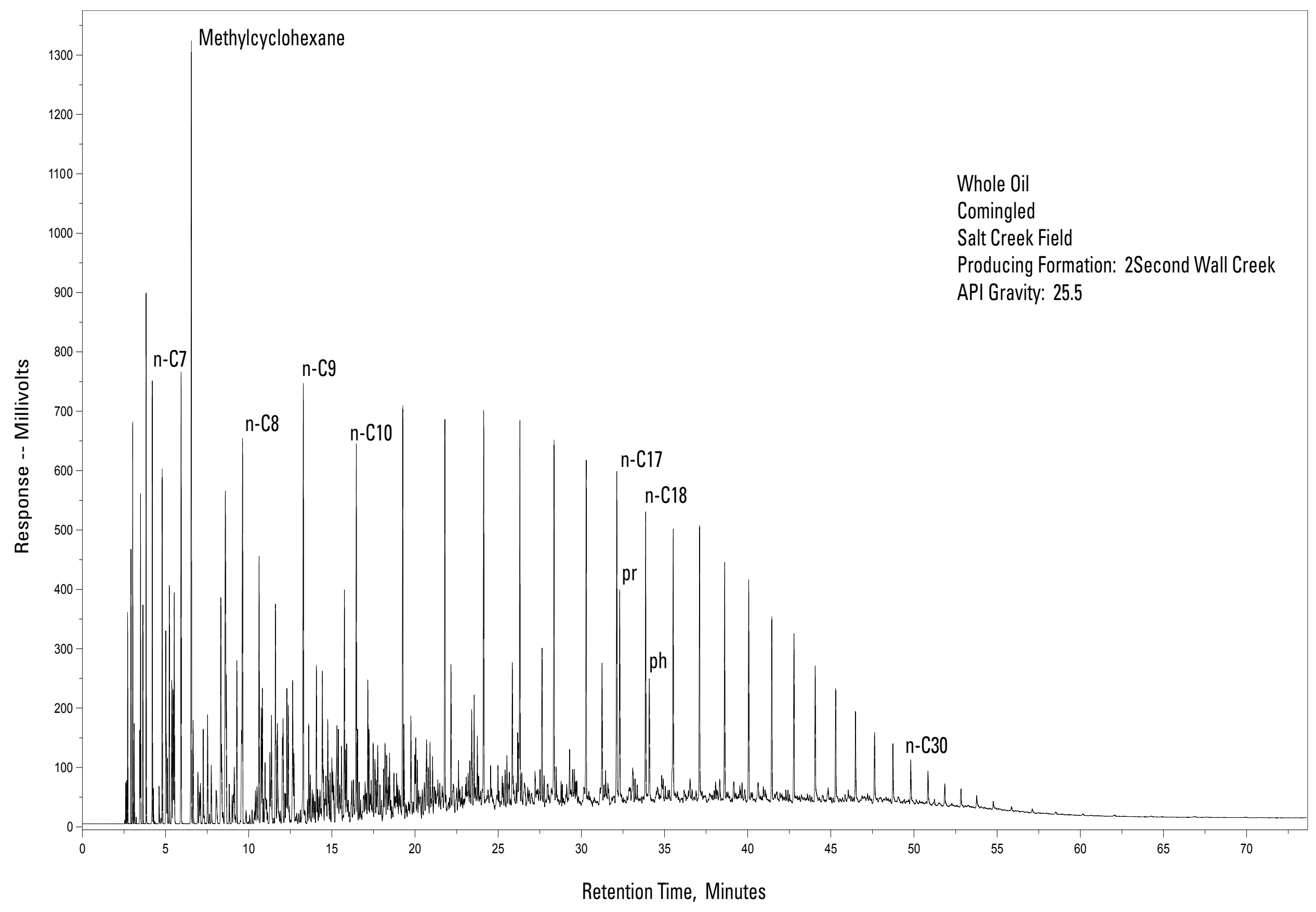

Figure 18: Whole oil gas chromatogram, Anadarko commingled sample, producing from the Second Wall Creek sand, Salt Creek field. Selected peak indentifications: $n-C x$, normal alkanes where $X$ is the carbon number; pr, pristane; ph, phytane. See figure 2 for well location. 


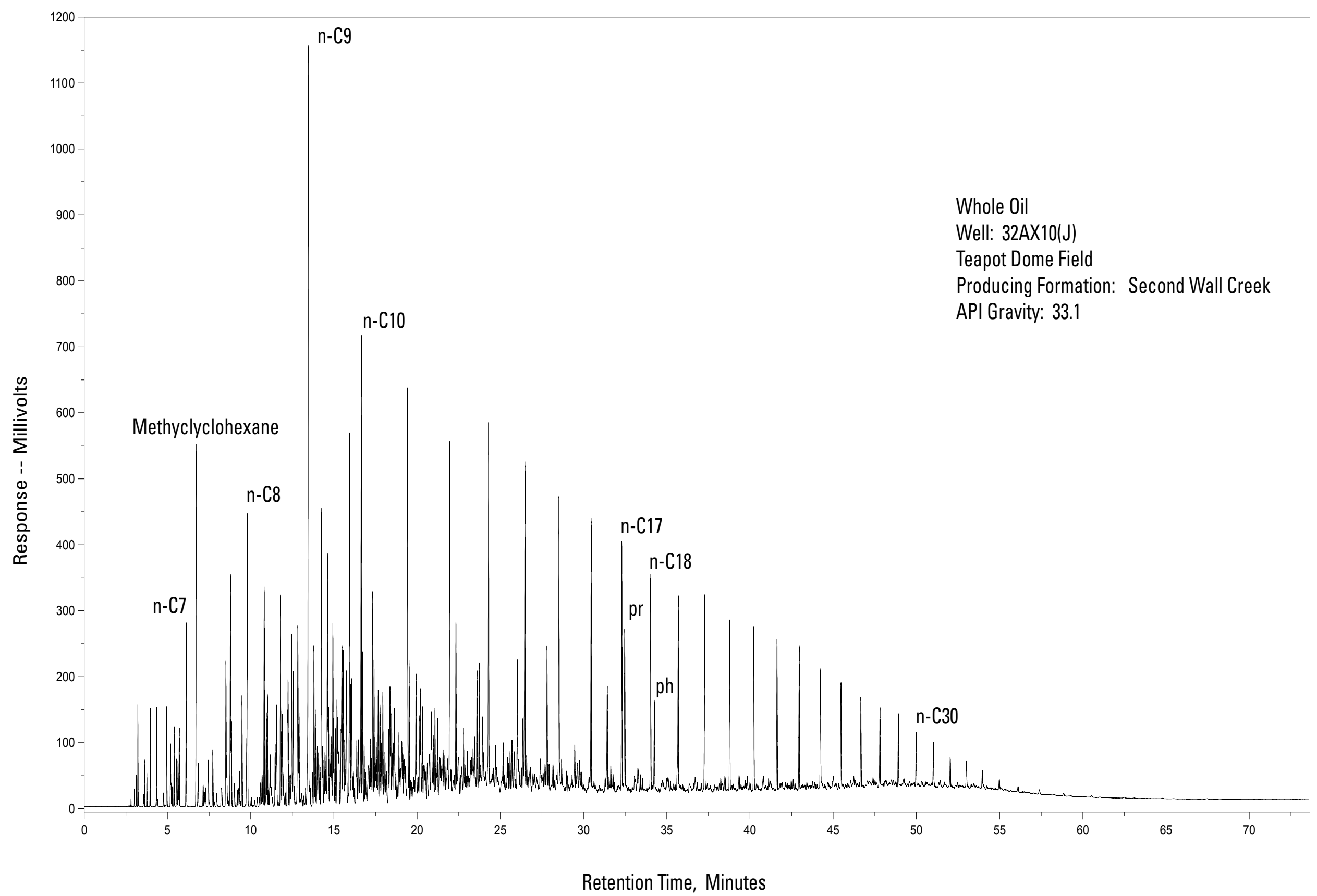

Figure 19: Whole oil gas chromatogram, well 32AX10(J), producing from the Second Wall Creek sand, Teapot Dome field.

Selected peak indentifications: $n-C x$, normal alkanes where $X$ is the carbon number; pr, pristane; ph, phytane. See figure 2 for well location. 


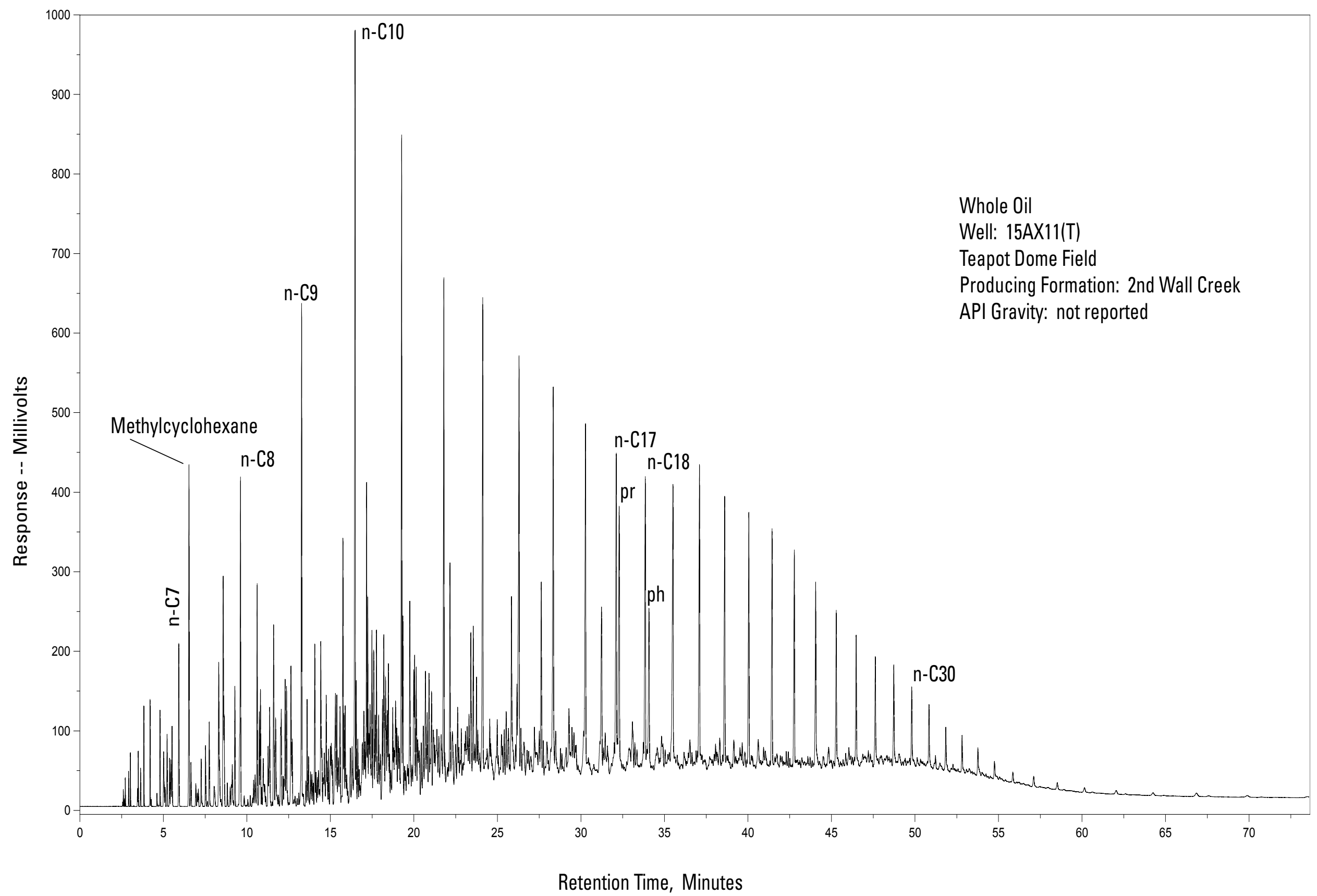

Figure 20: Whole oil gas chromatogram, well 15AX11(T), producing from the Second Wall Creek sand, Teapot Dome field.

Selected peak indentifications: $n$ - $C x$, normal alkanes where $X$ is the carbon number; pr, pristane; ph, phytane. See figure 2 for well location. 


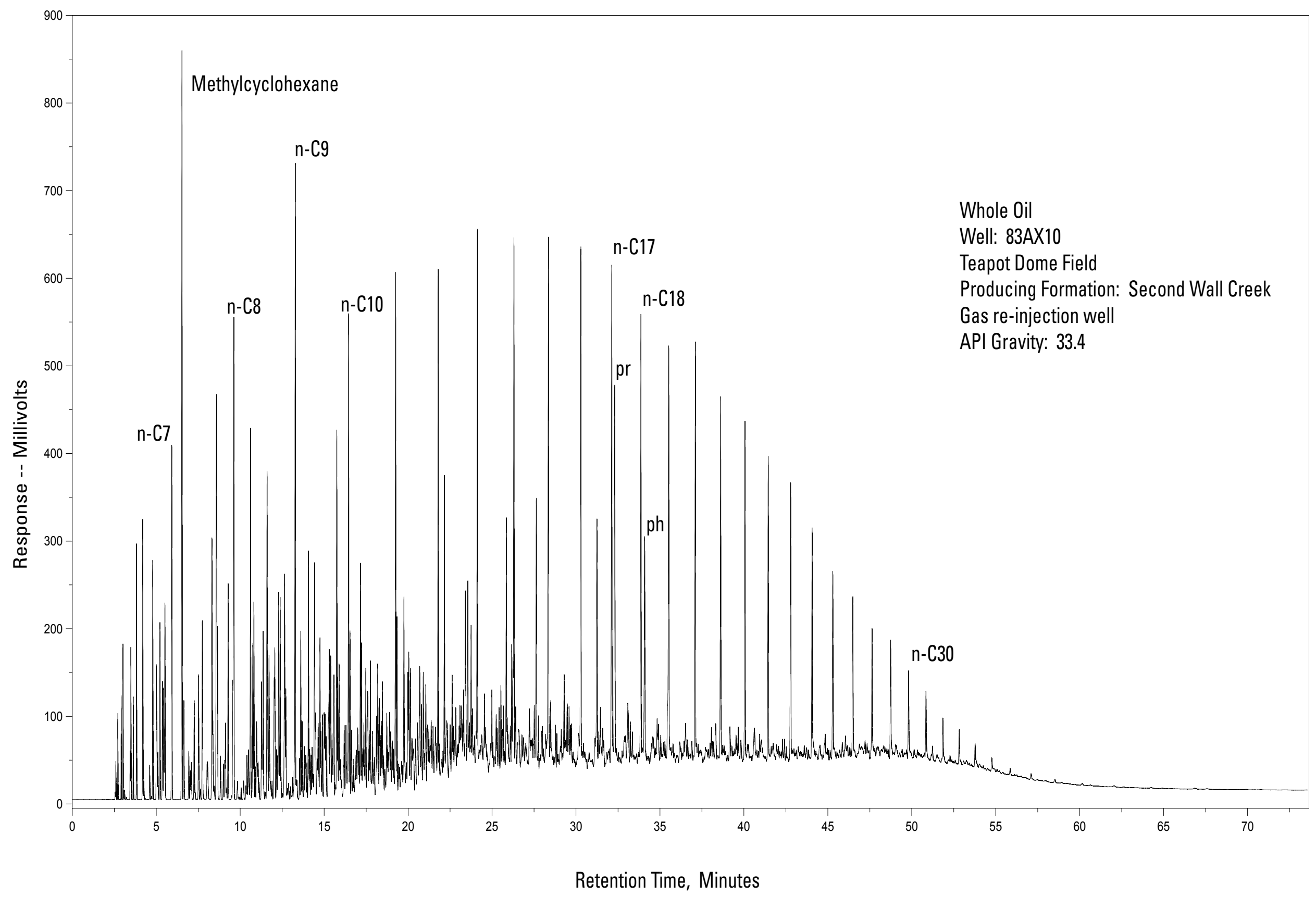

Figure 21: Whole oil gas chromatogram, well 83AX10, producing from the Second Wall Creek sand, Teapot Dome field.

Selected peak indentifications: $n-C x$, normal alkanes where X is the carbon number; pr, pristane; ph, phytane. See figure 2 for well location. 


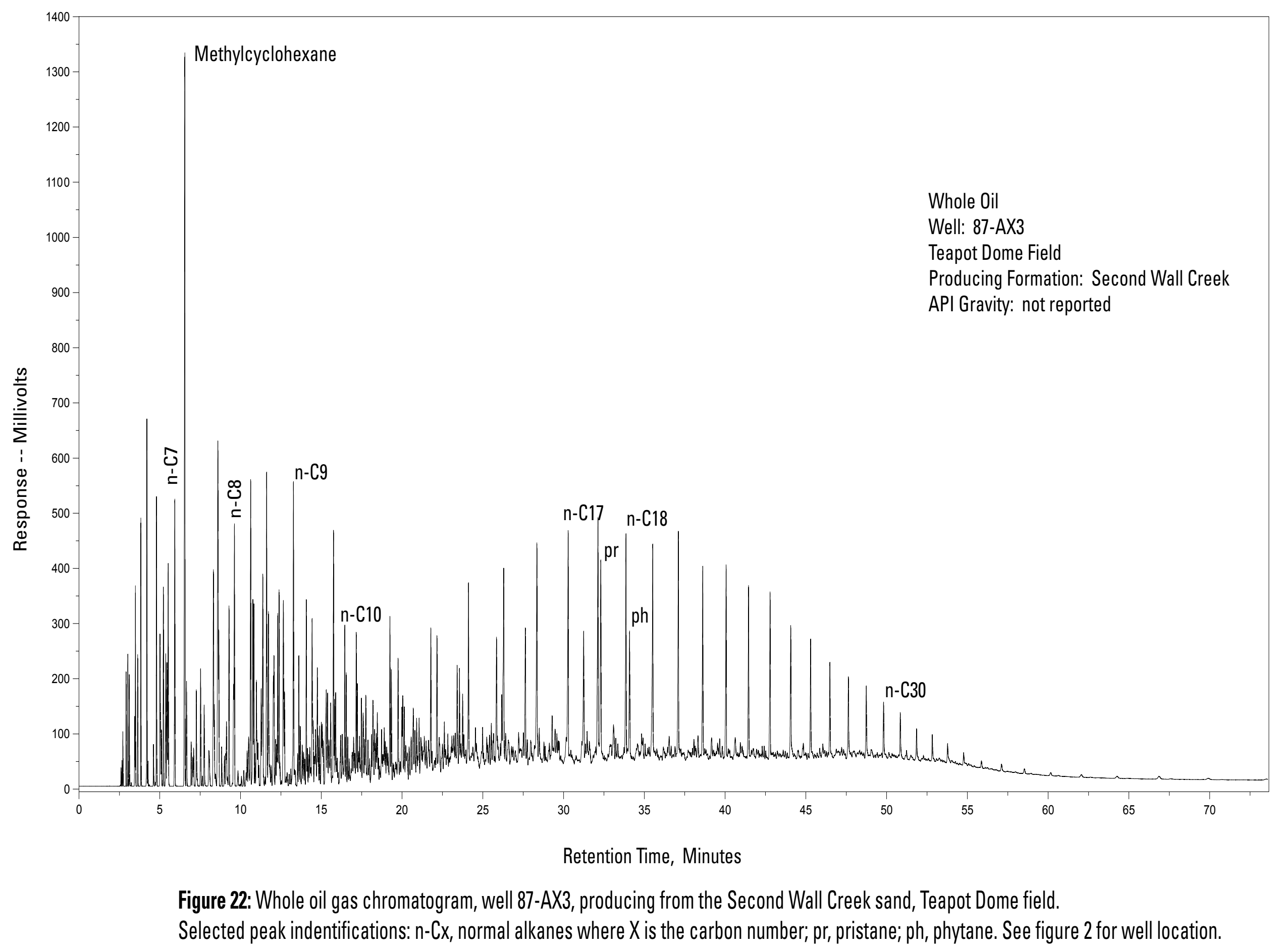




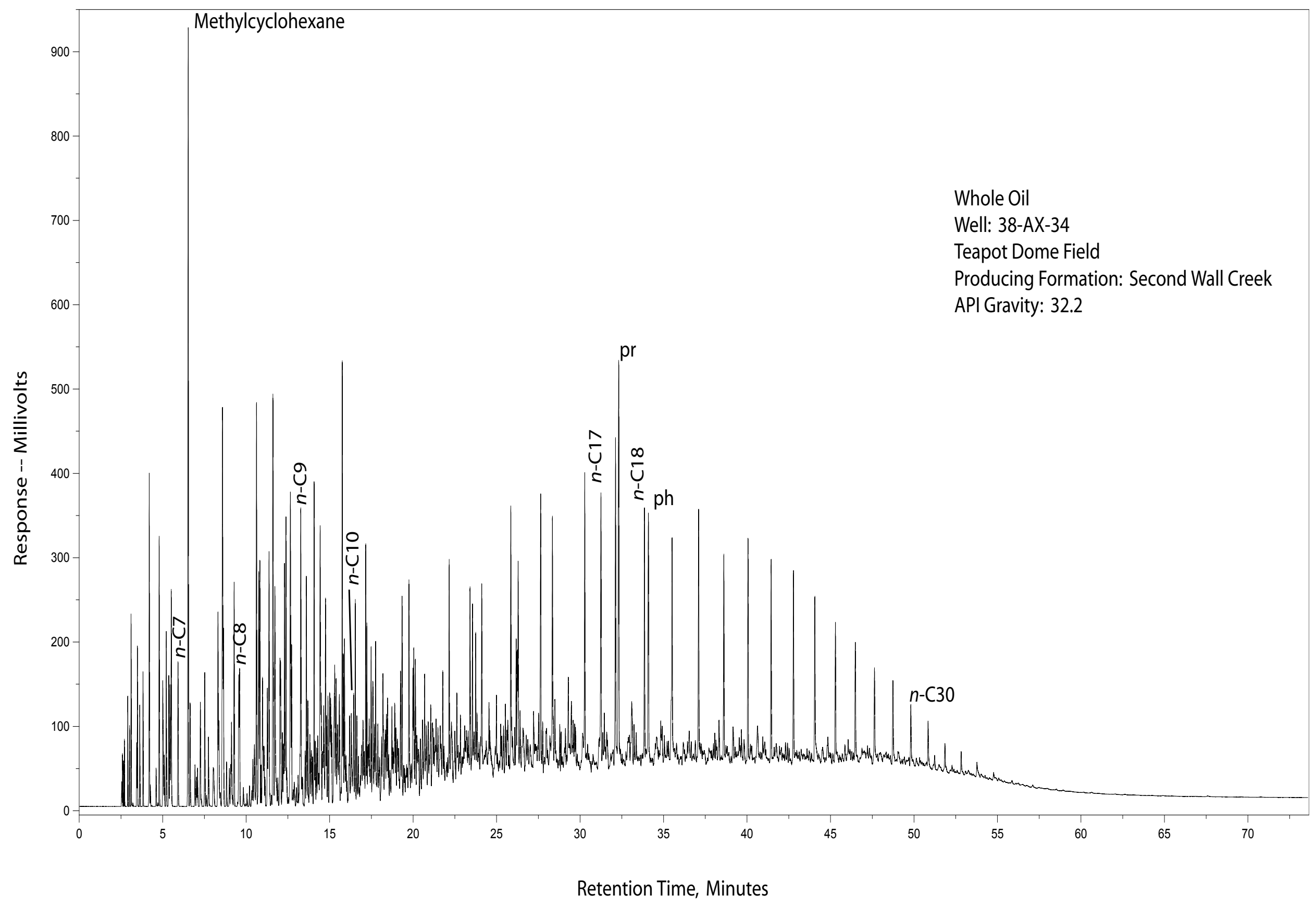

Figure 23: Whole oil gas chromatogram, well 38-AX-34, producing from the Second Wall Creek sand, Teapot Dome field.

Selected peak indentifications: $n$ - $C x$, normal alkanes where $\mathrm{X}$ is the carbon number; pr, pristane; ph, phytane. See figure 2 for well location. 


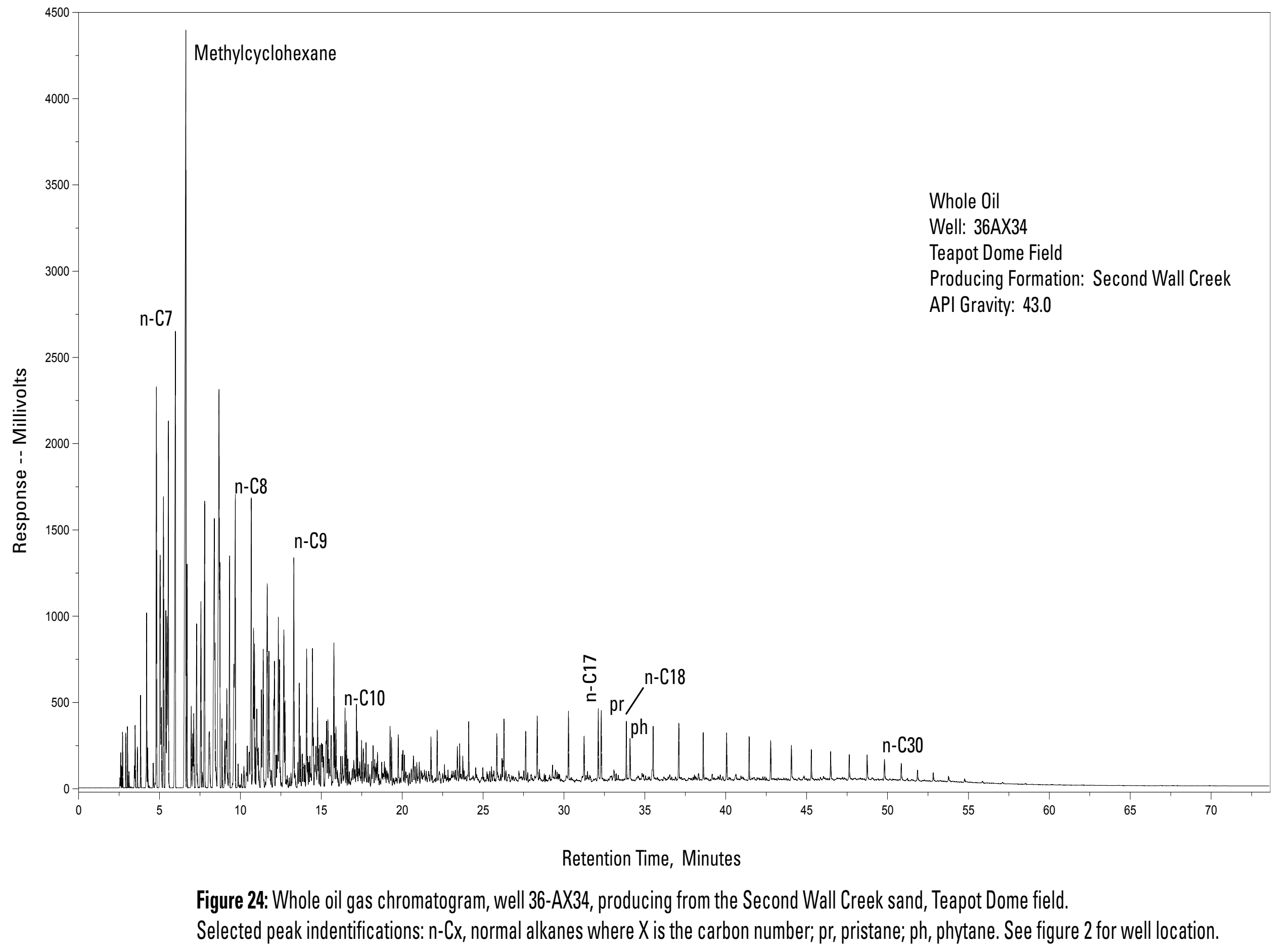




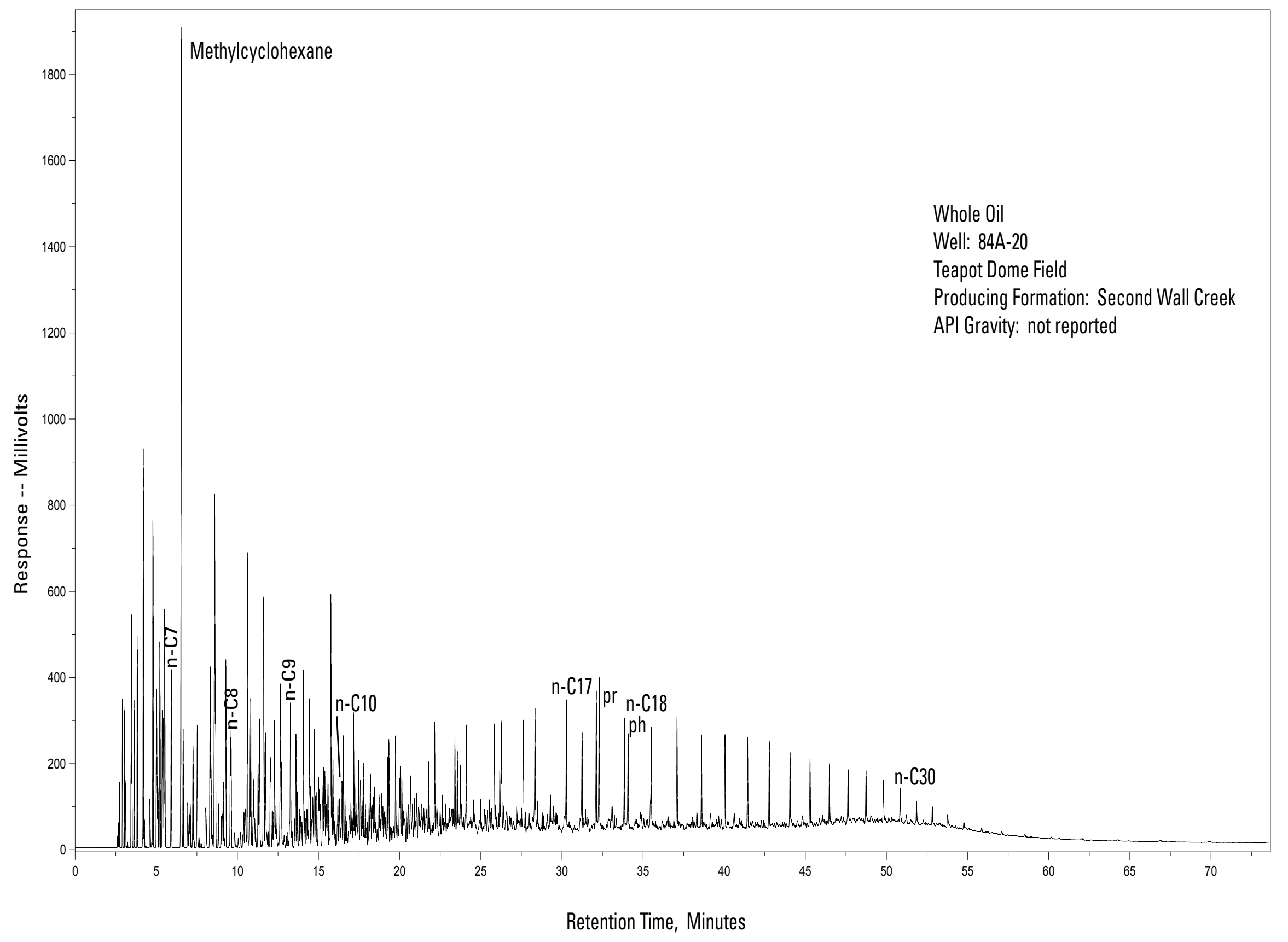

Figure 25: Whole oil gas chromatogram, well 84A-20, producing from the Second Wall Creek sand, Teapot Dome field.

Selected peak indentifications: $n-C x$, normal alkanes where $X$ is the carbon number; pr, pristane; ph, phytane. See figure 2 for well location. 


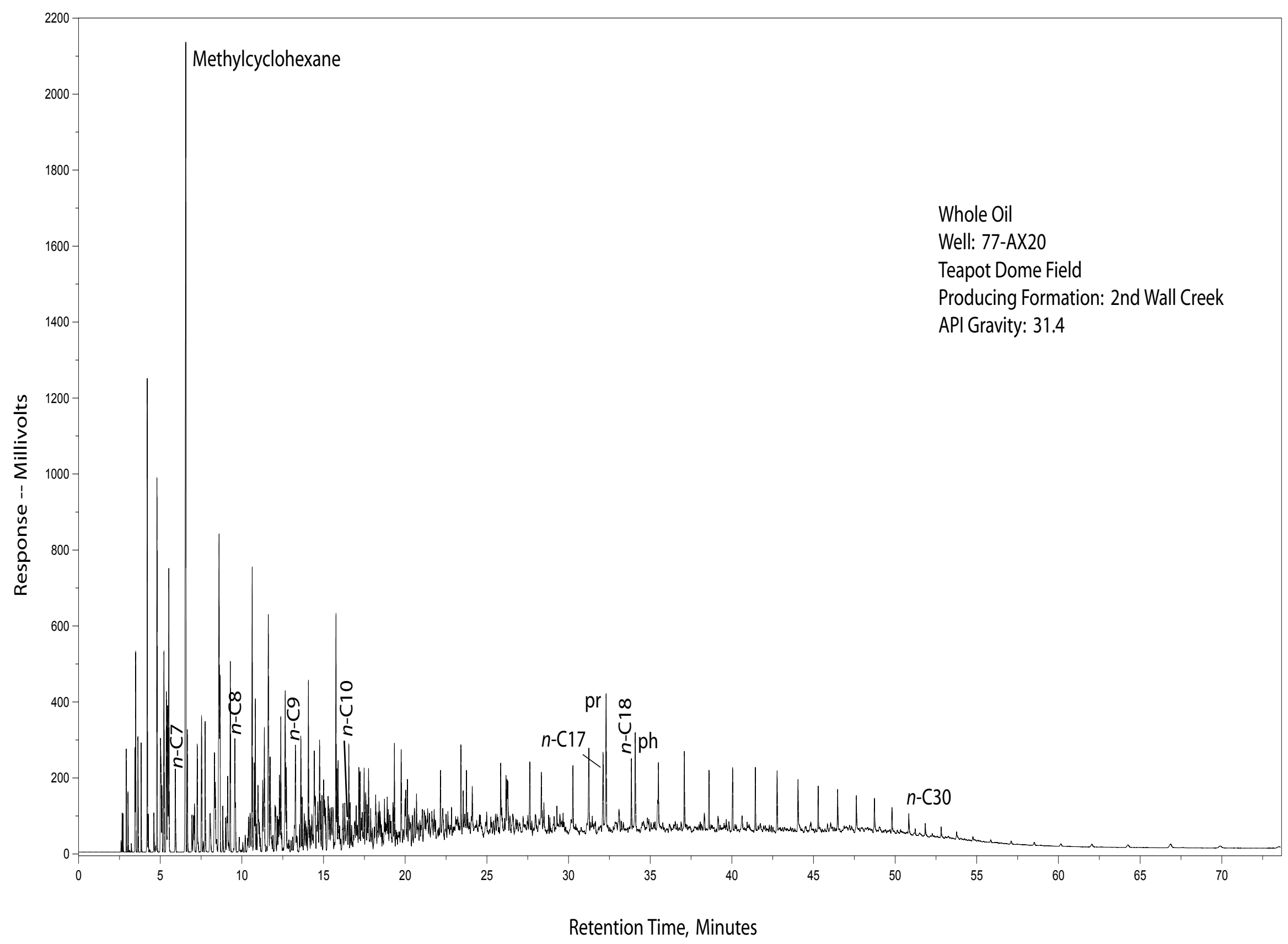

Figure 26: Whole oil gas chromatogram, well 77-AX20, producing from the Second Wall Creek sand, Teapot Dome field.

Selected peak indentifications: $n-C x$, normal alkanes where $X$ is the carbon number; pr, pristane; ph, phytane. See figure 2 for well location. 


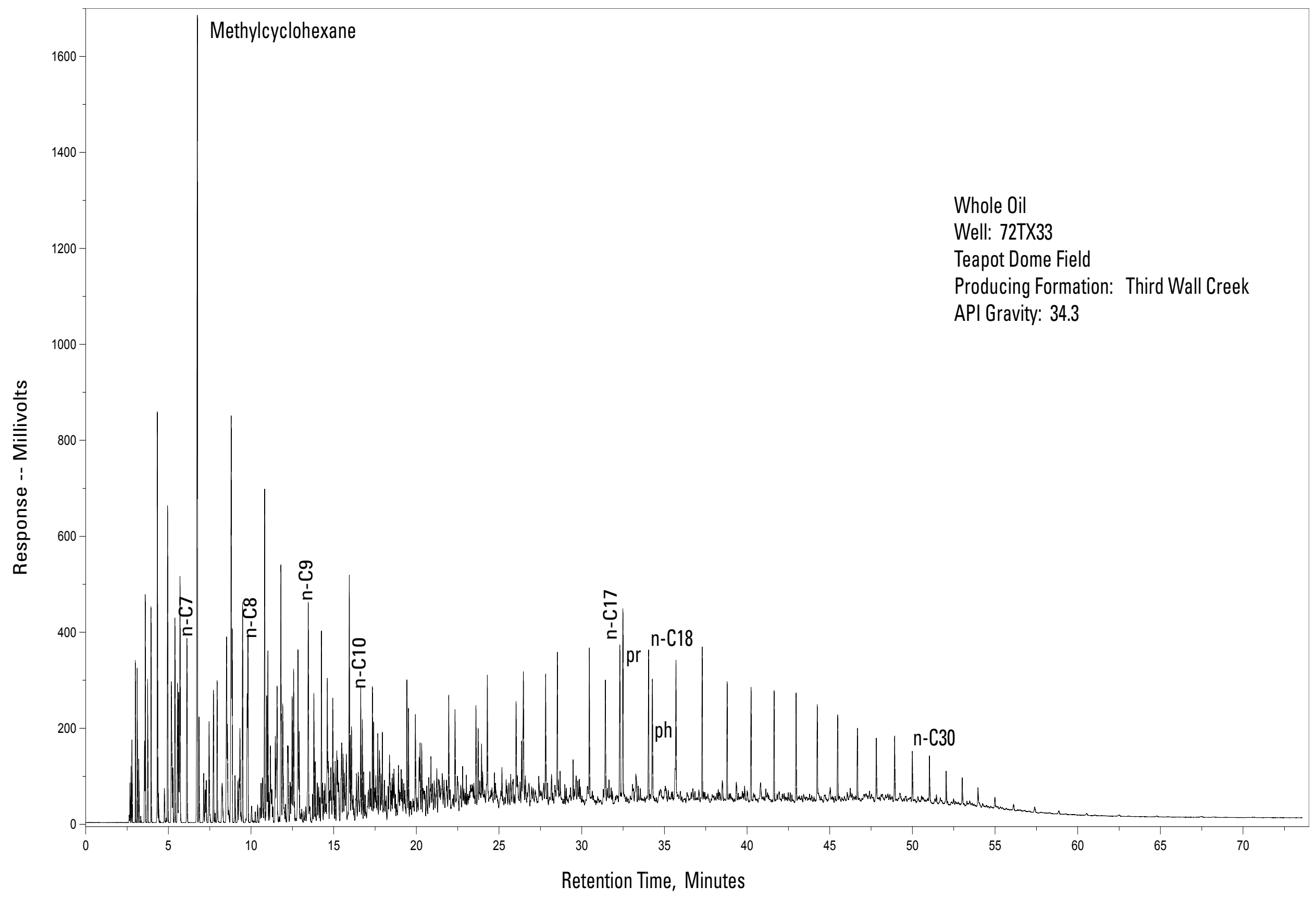

Figure 27: Whole oil gas chromatogram, well 72TX33, producing from the Third Wall Creek sand, Teapot Dome field.

Selected peak indentifications: $n-C x$, normal alkanes where $X$ is the carbon number; pr, pristane; ph, phytane. See figure 2 for well location. 


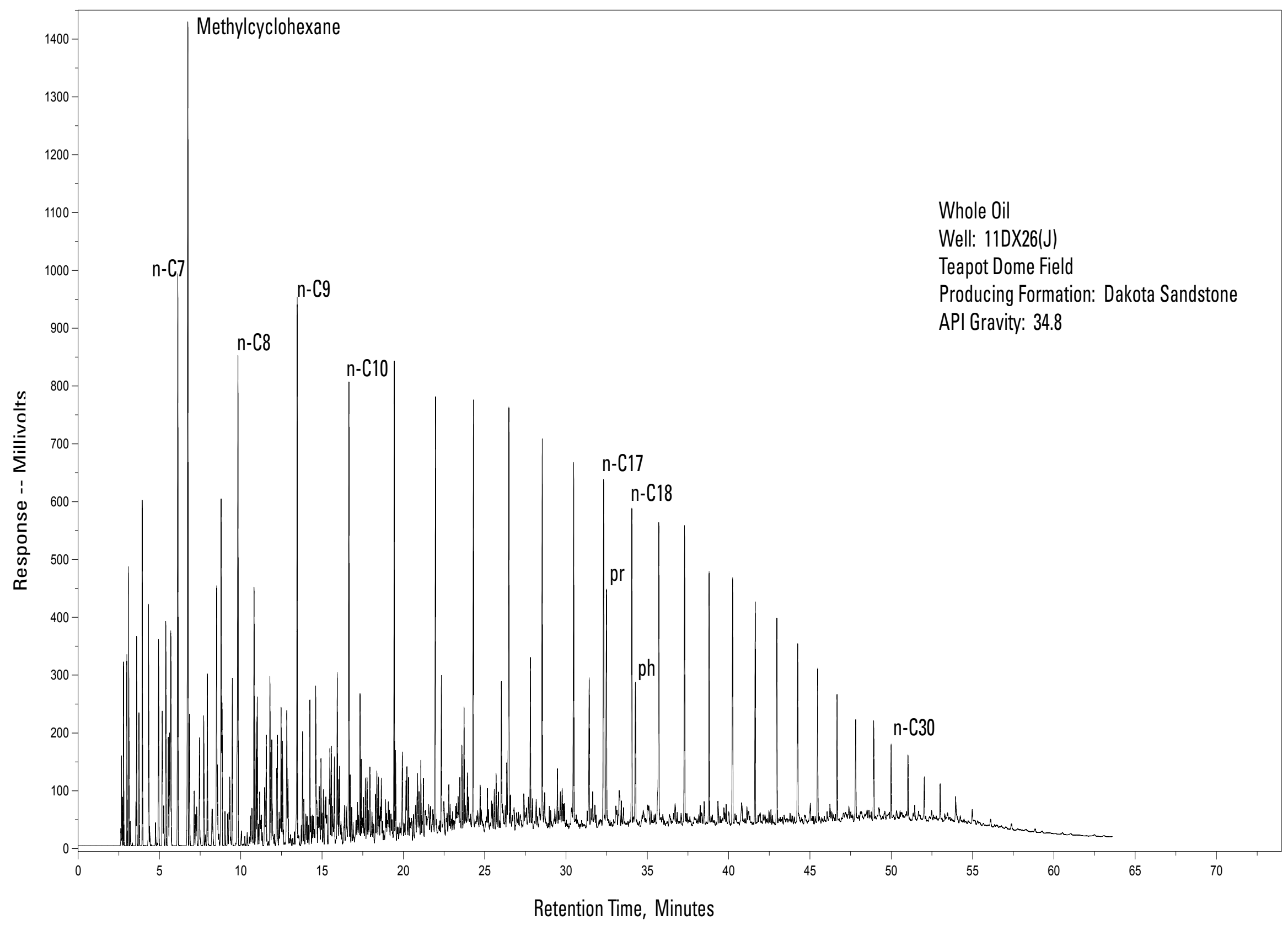

Figure 28: Whole oil gas chromatogram, well 11DX26(J), producing from the Fall River Formation (Dakota), Teapot Dome field. Selected peak indentifications: $n-C x$, normal alkanes where $X$ is the carbon number; pr, pristane; ph, phytane. See figure 2 for well location. 


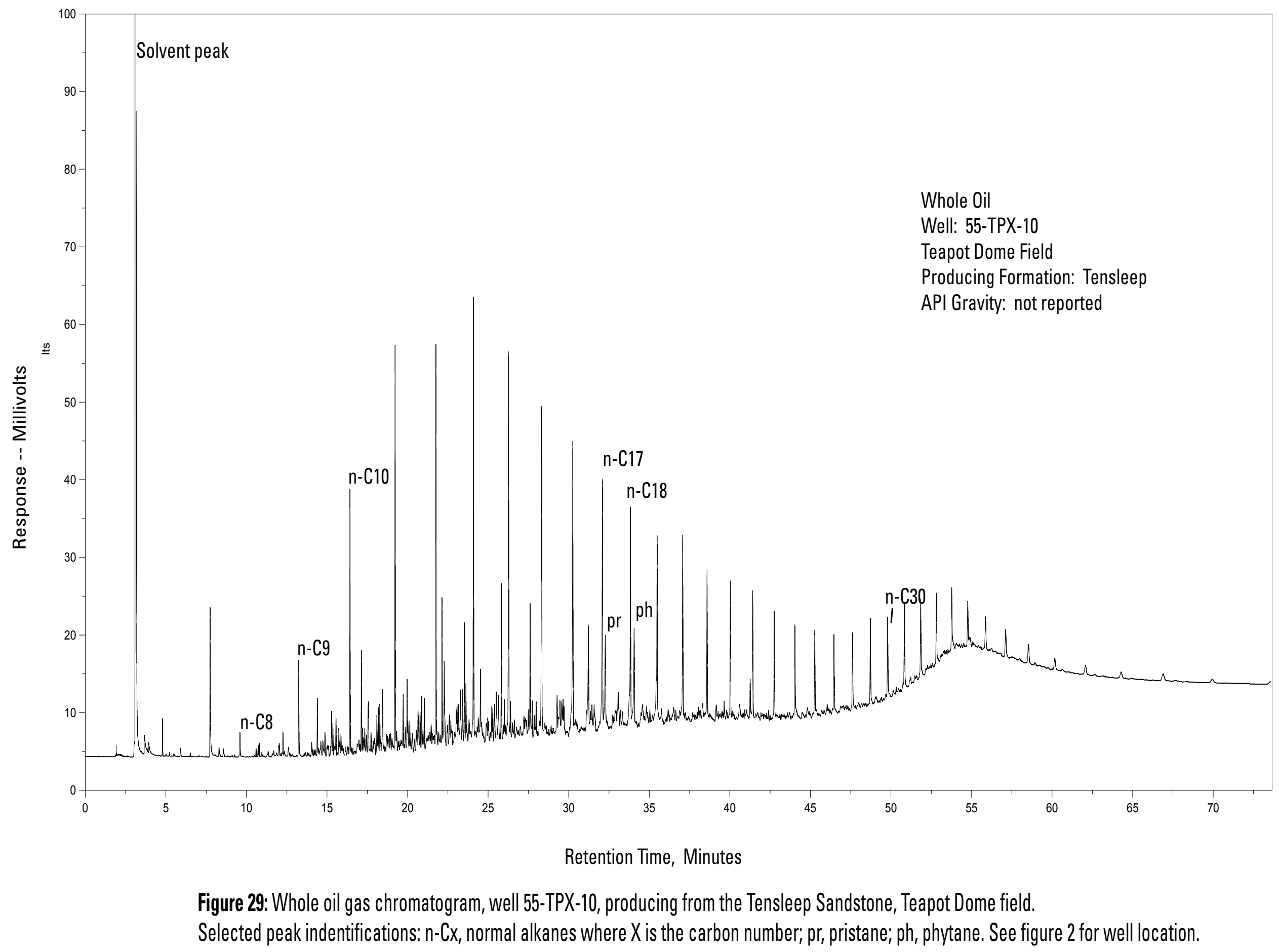




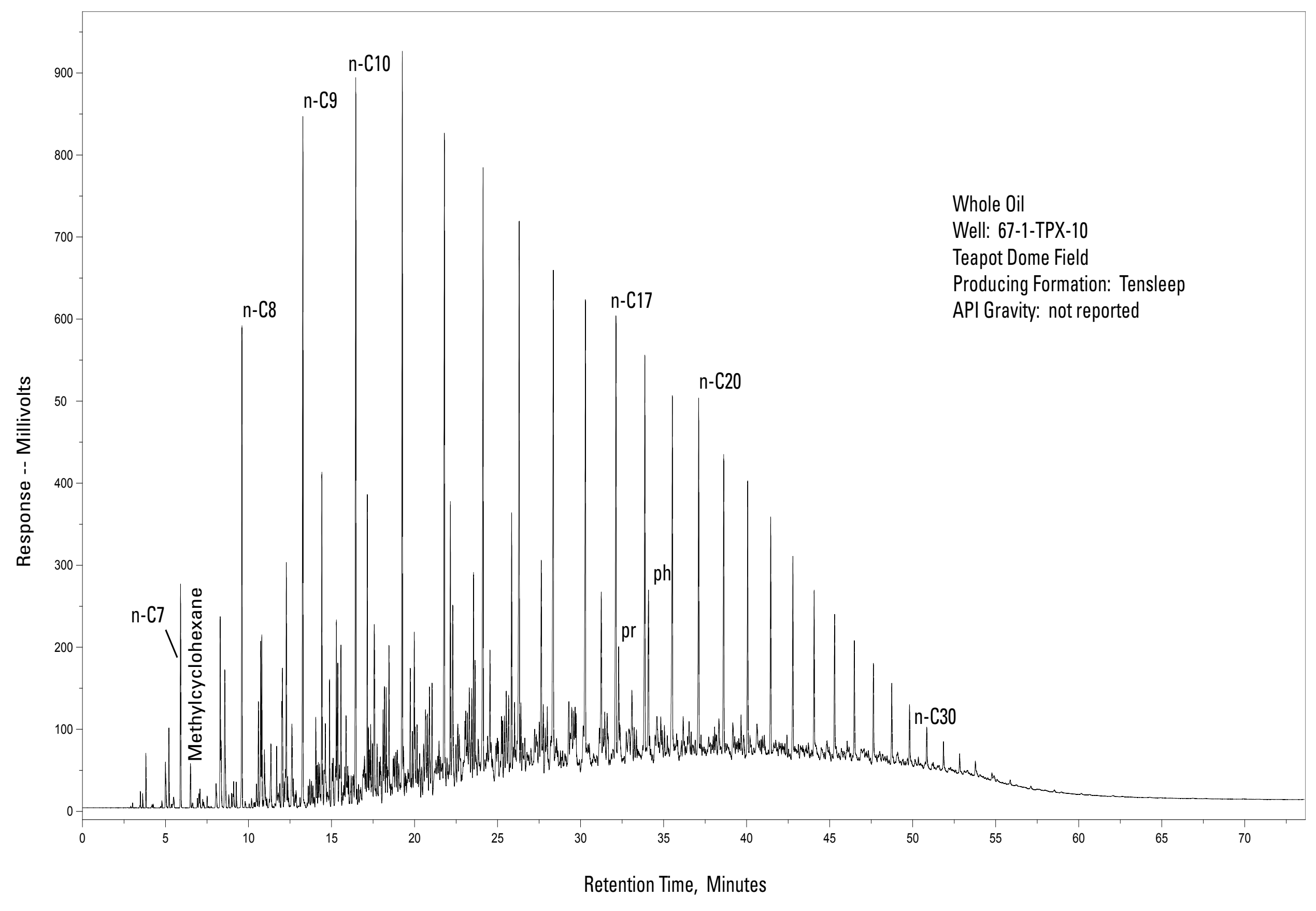

Figure 30: Whole oil gas chromatogram, well 67-1-TPX-10, producing from the Tensleep Sandstone, Teapot Dome field.

Selected peak indentifications: $n$ - $C x$, normal alkanes where $X$ is the carbon number; pr, pristane; ph, phytane. See figure 2 for well location. 


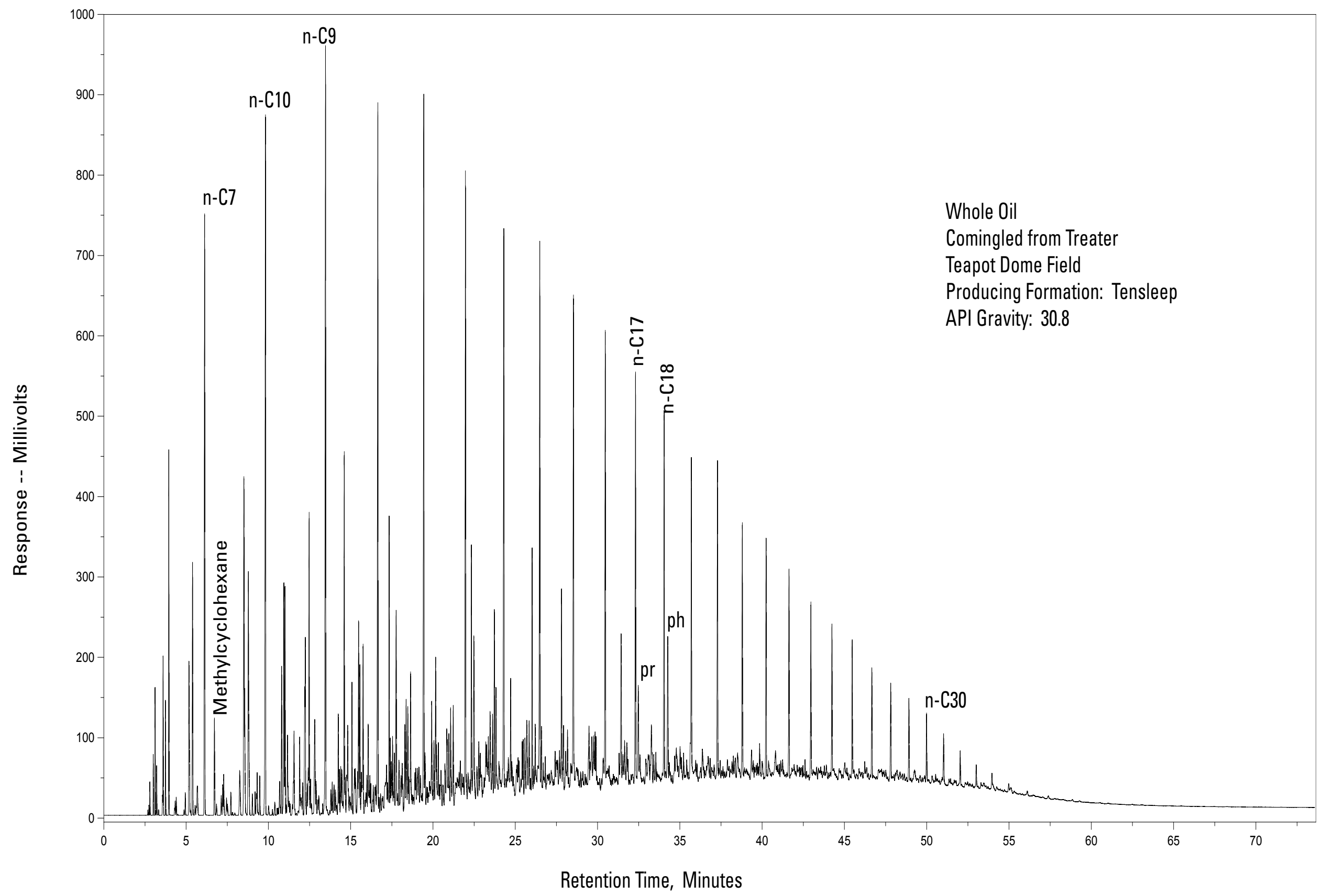

Figure 31: Whole oil gas chromatogram, Comingled sample from treater, producing from the Tensleep Sandstone, Teapot Dome field. Selected peak indentifications: $n-C x$, normal alkanes where $X$ is the carbon number; pr, pristane; ph, phytane. See figure 2 for sample location. 


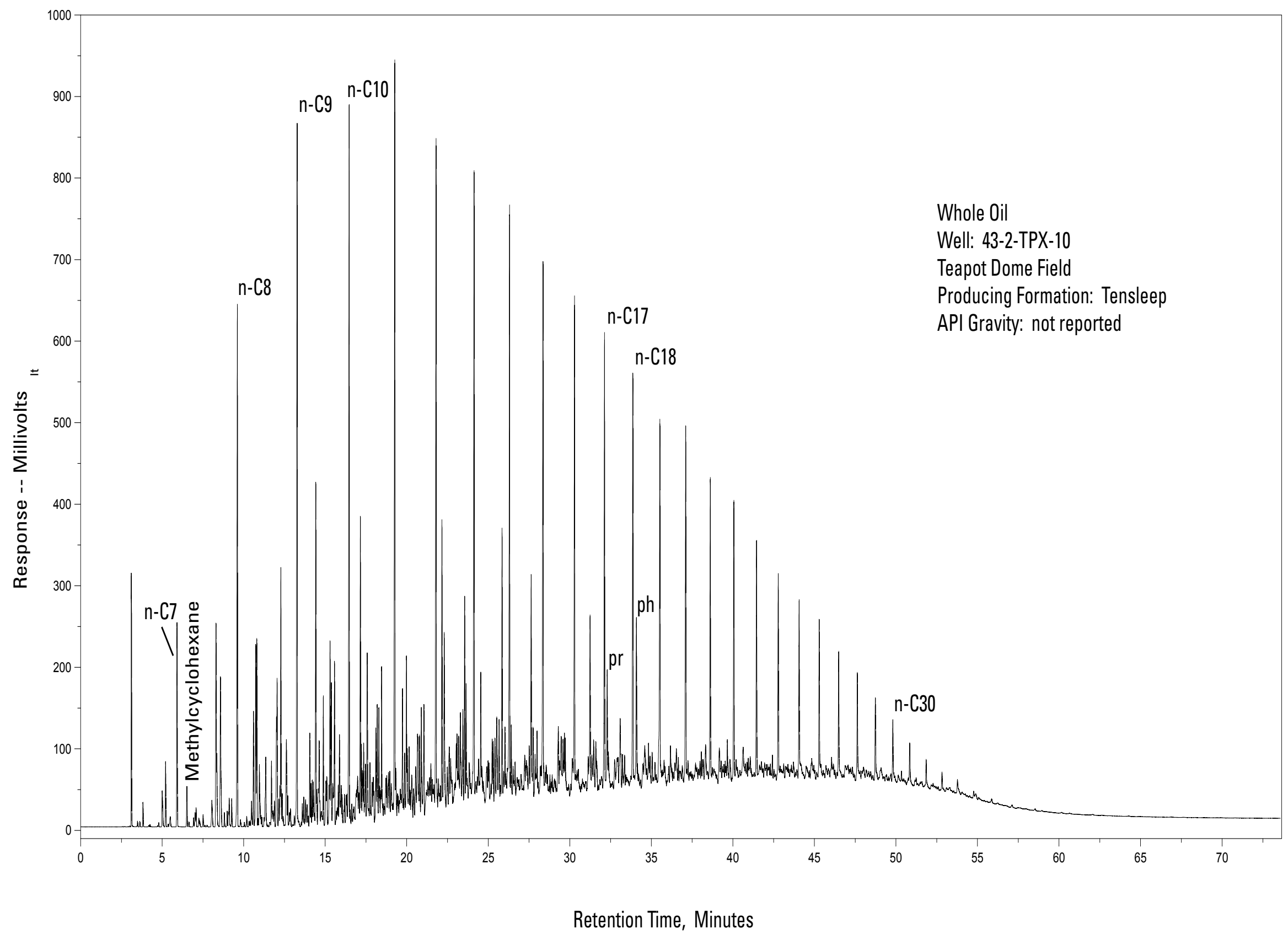

Figure 32: Whole oil gas chromatogram, well 43-2-TPX-10, producing from the Tensleep Sandstone, Teapot Dome field.

Selected peak indentifications: $n$-Cx, normal alkanes where $X$ is the carbon number; pr, pristane; ph, phytane. See figure 2 for well location. 


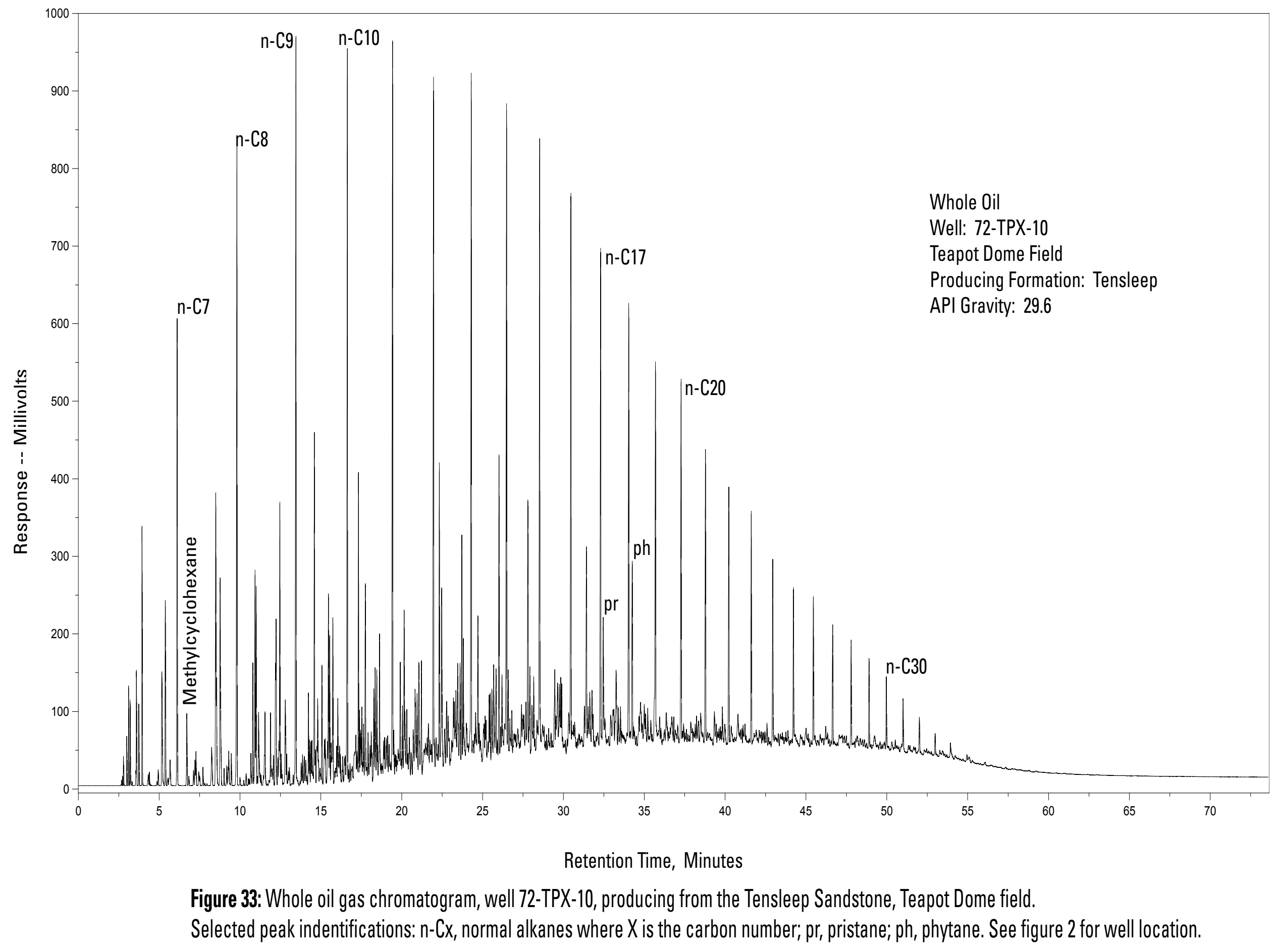




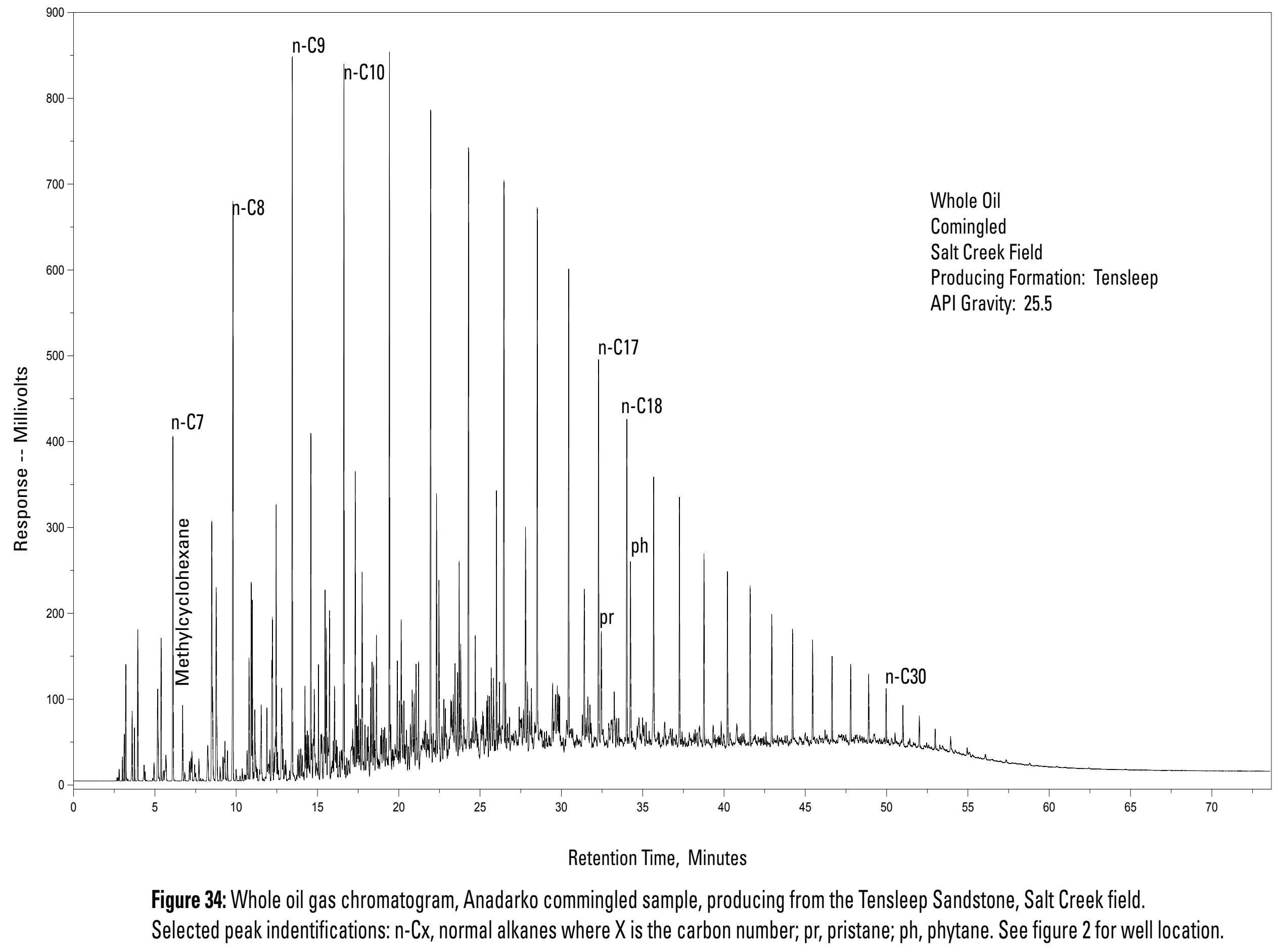




\section{Characteristics of Oils and Reservoirs in the Teapot Dome Field}

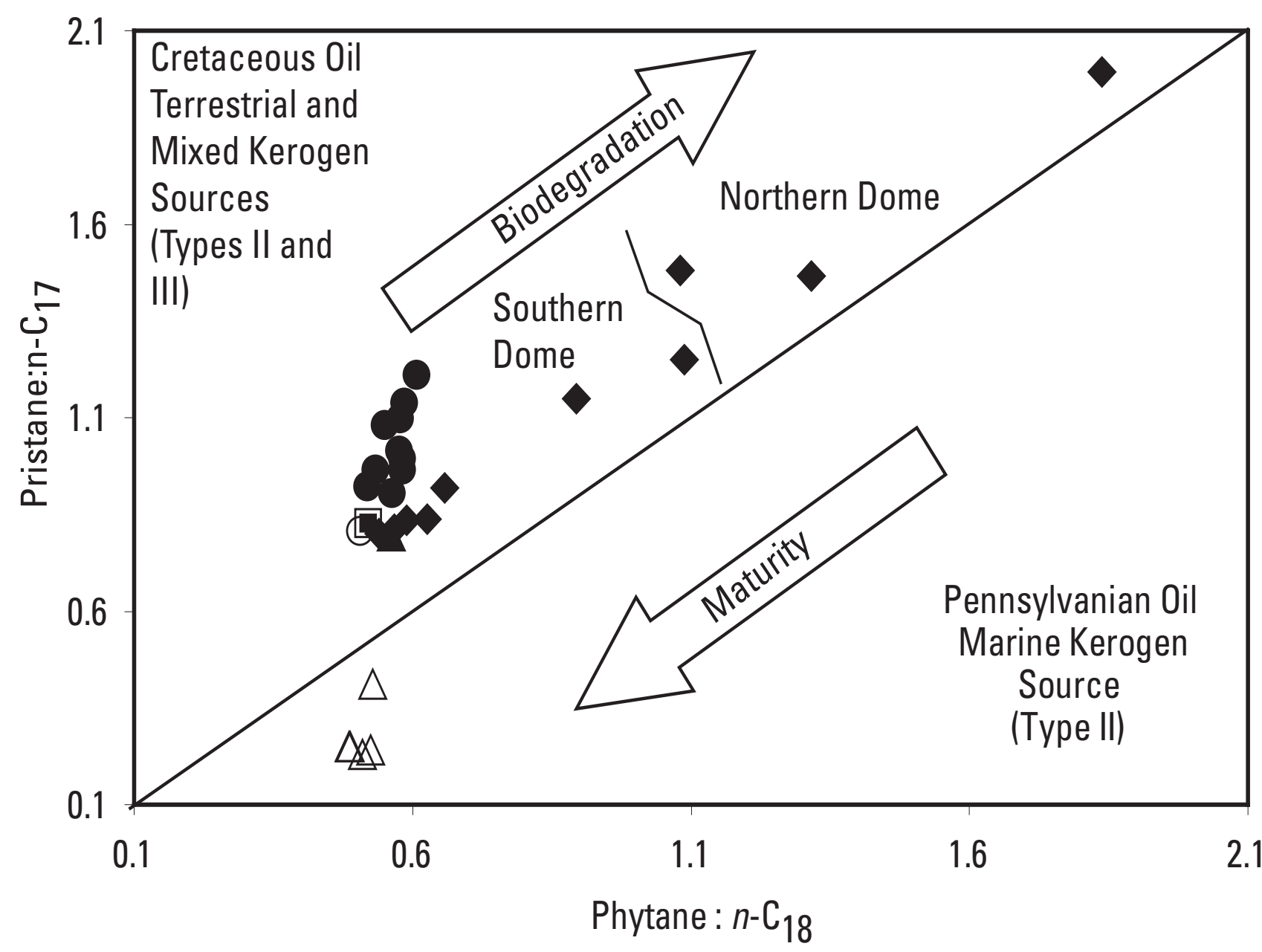

Legend

- Shannon Sandstone

Cretaceous Shales

Wall Creek Sands

A Dakota Sandstone

$\triangle$ Tensleep Sandstone

Figure 35. Distributions of samples from the reservoirs in the Teapot Dome field relative to different parent material (kerogen) depositional environments. The diagonal line separates the two different kerogen source environments on the basis of the ratios of $n$-alkanes to isoprenoids. The arrows indicate other processes affecting the geochemical characteristics of oils such as biodegradation and source rock maturity. The zig-zag line separates the Cretaceous samples into those from the northern dome and those from the southern dome of the Teapot Dome field. After Hunt, 1996. 


\section{Alteration Trends in Upper Cretaceous Sandstone Reservoirs}

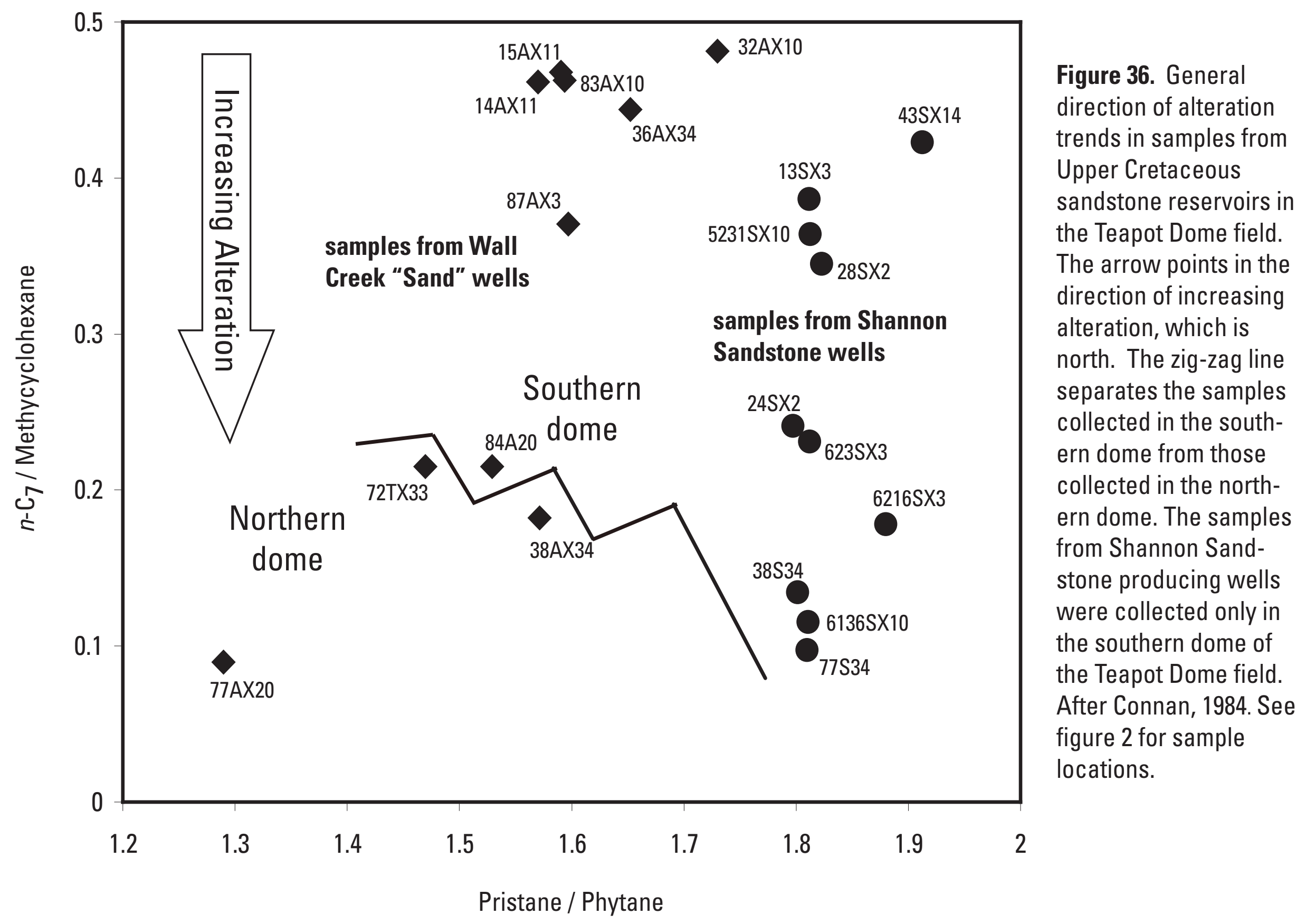




\section{June 2004 Baseline \\ Gas Sample Profiles}

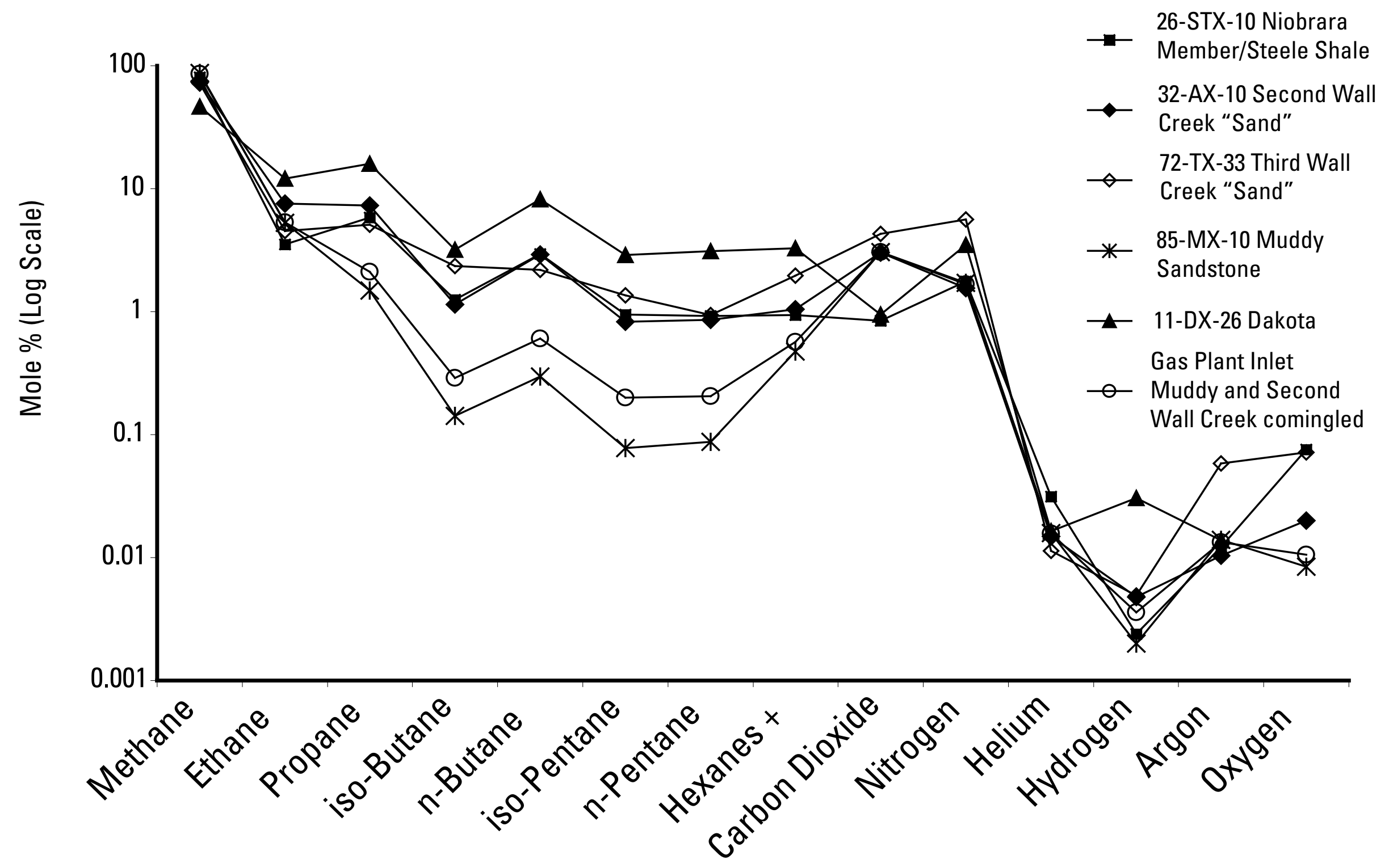

Wells in Stratigraphic Order by Producing Formation

6-STX-10 Niobrara

(Steele Shale

32-AX-10 Second Wall (2) Wall 85-MX-10 Muddy andstone Muddy and Second

Figure 37. Relative concentrations of hydrocarbon and non-hydrocarbon components of gas samples taken at the Teapot Dome field in June, 2004. 
$\delta^{13} \mathrm{C}$ value for Pierre Shale organic

\section{Natural Gas Plot}

carbon, eastern equivalent of the

Cody Shale, possible hydrocarbon

source value and hypothetical

starting point for thermal cracking
- 32-AX-10 Second Wall Creek Sand Well $2998 \mathrm{ft}$.

\ 11-DX-26 Dakota Sandstone Well $4965 \mathrm{ft}$.

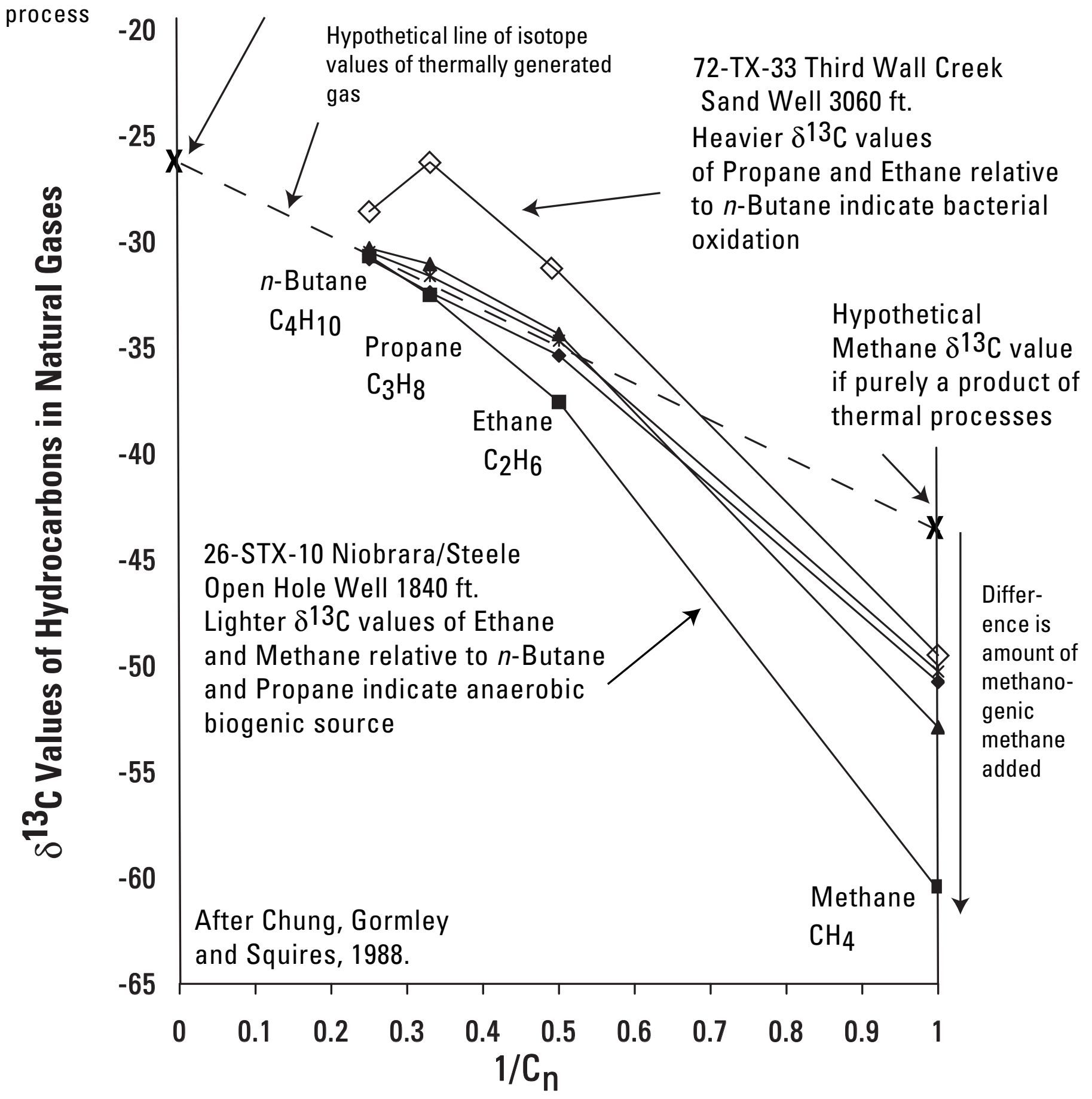

Figure 38. This plot is based on the assumption that natural gases are generated by thermal cracking of isotopically homogenous parent kerogen molecules. For example, the cracking process from $n$-butane to propane should theoretically result in isotopically lighter propane, because the $\delta^{12} \mathrm{C}-\delta^{12} \mathrm{C}$ bond is easier to break than the $\delta^{12} \mathrm{C}-\delta^{13} \mathrm{C}$ bond, thus enriching the cracked molecules in the lighter isotope. A natural gas plot of purely thermally cracked gas should be a straight line (shown by dotted line) with methane having the most negative $\delta^{13} \mathrm{C}$ values. Deviations from the linear relationship of progressive isotope enrichment with decreasing carbon number are usually the result of mixing or microbial alteration. 


\section{Sources of Methane in Teapot Dome Wells}

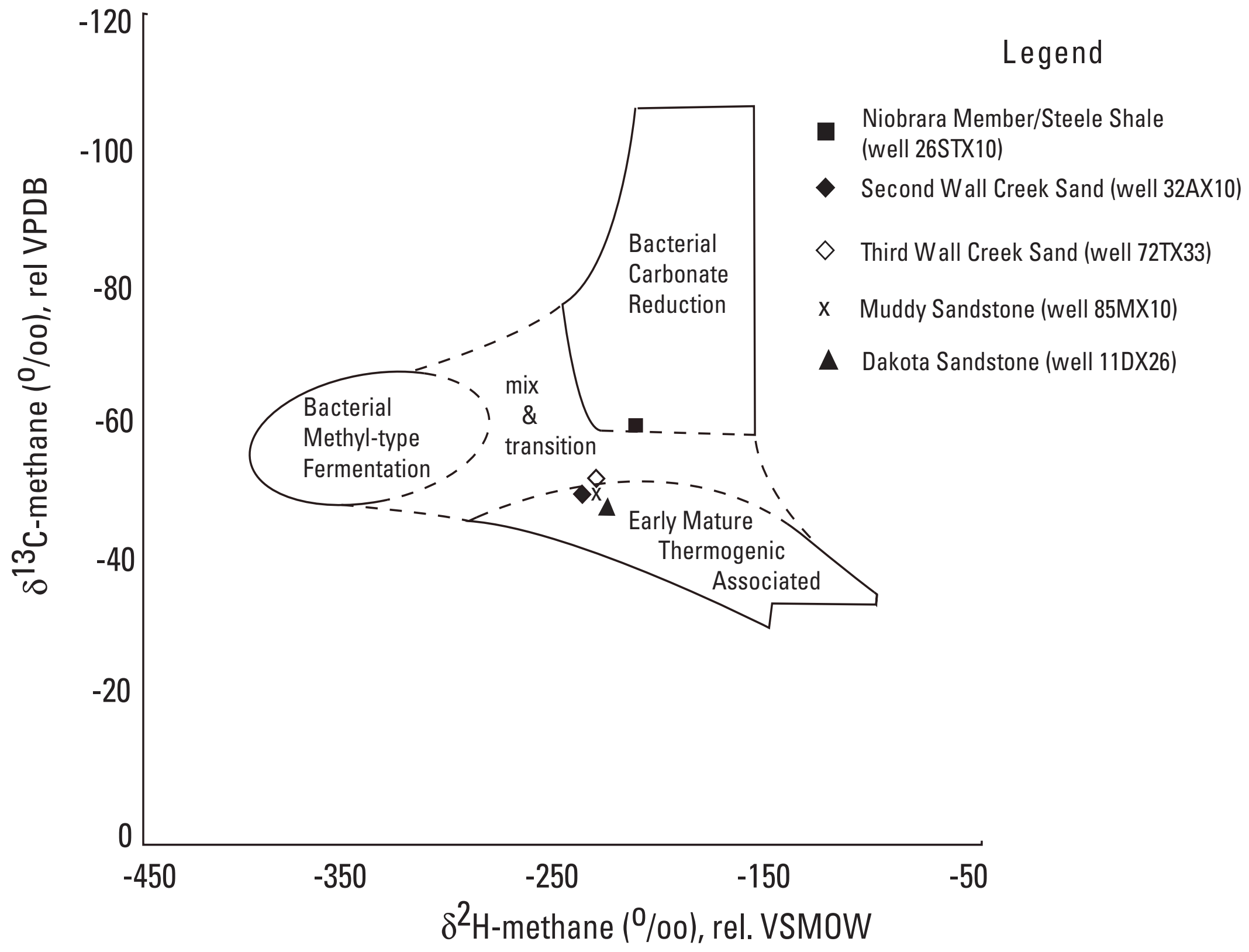

Figure 39. Sources of methane in the gas samples originating by different processes, based on natural isotopic abundances of carbon and hydrogen in methane. All the wells contain varying mixtures of thermogenic and microbial gas. After Whiticar, 1996. 


\section{Biodegradation of $\mathbf{C}_{2}$ - Gases}

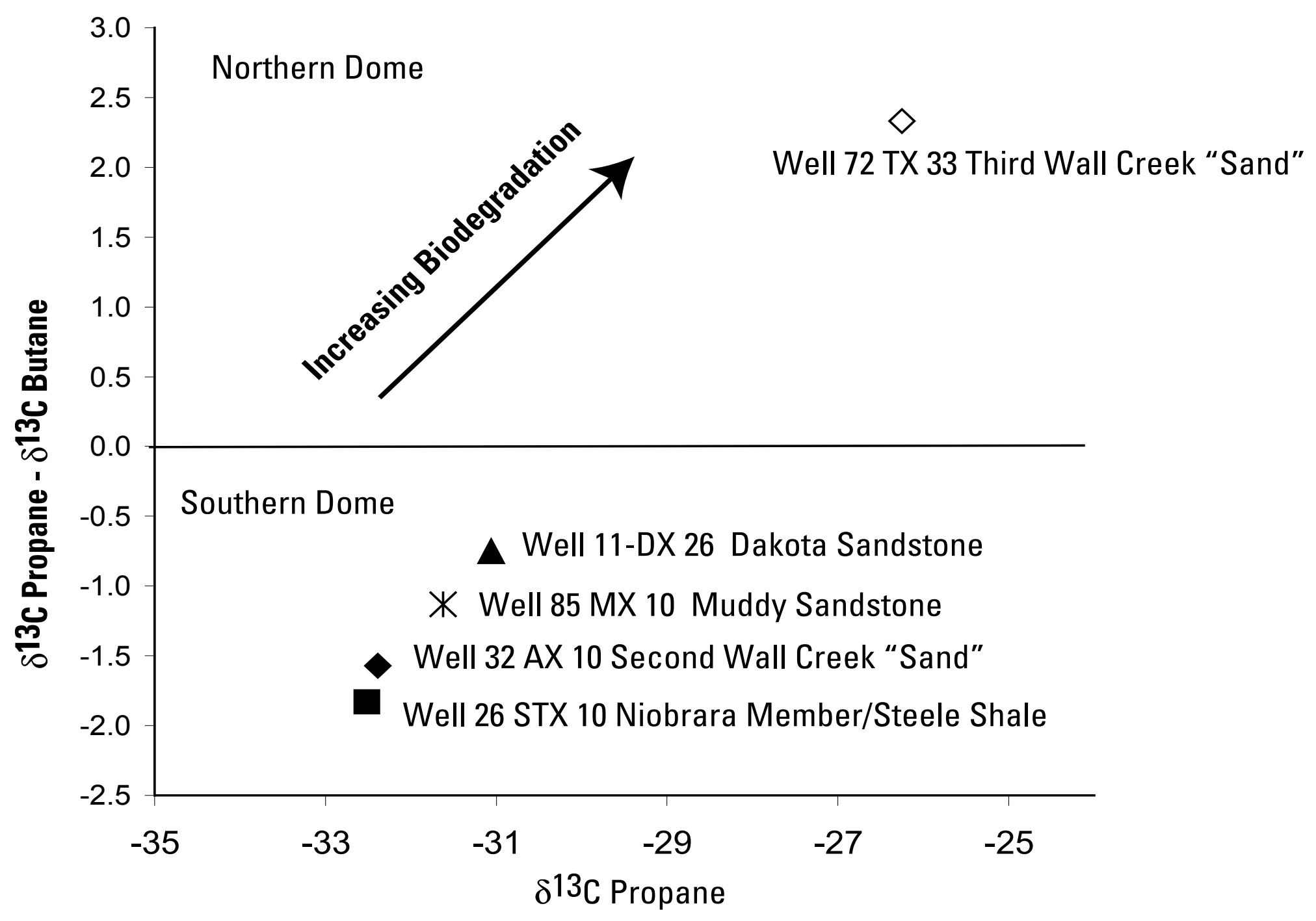

Figure 40. Trend in biological alteration of $n$-butane and propane from wells in the Teapot Dome field after Wenger (2002). Because bacteria prefer to oxidize propane relative to $n$-butane, bacterially degraded gases will exhibit more positive propane $\delta^{13} \mathrm{C}$ values relative to their $\delta^{13} \mathrm{C}$ values for $n$-butane. For more highly biodegraded gases, the difference between the $\delta^{13} \mathrm{C}$ propane and $\delta^{13} \mathrm{C} n$-butane values divided by the $\delta^{13} \mathrm{C}$ propane value will be a positive number, as shown for the Third Wall Creek "Sand" sample (well 72TX33). 


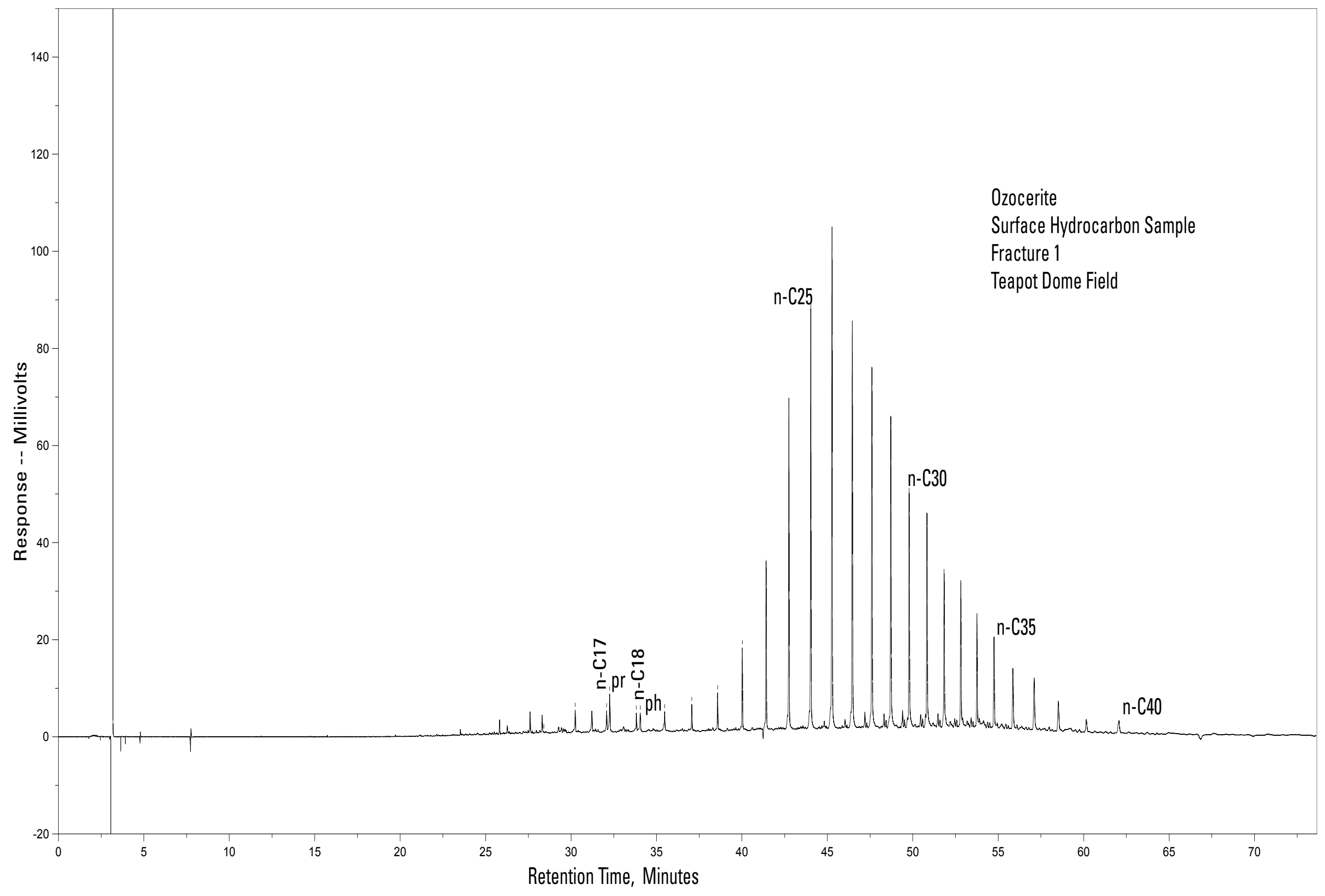

Figure 41: Ozocerite gas chromatogram, Surface Hydrocarbon Sample, Fracture 1, Teapot Dome field.

Selected peak indentifications: $n-C x$, normal alkanes where $X$ is the carbon number; pr, pristane; ph, phytane. See figure 2 for sample location. 


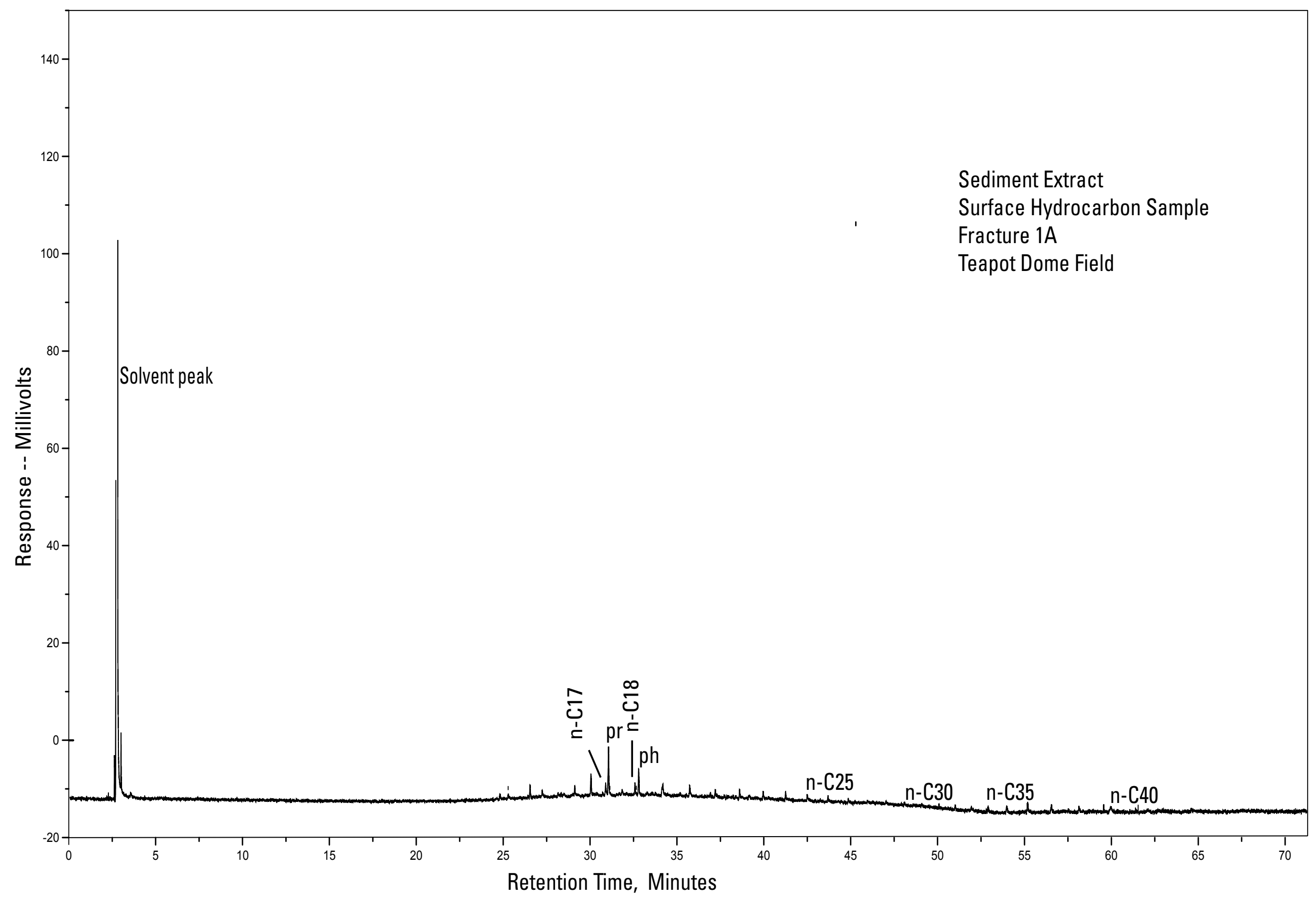

Figure 42: Sediment extract gas chromatogram, Surface Hydrocarbon Sample, Fracture 1A, Teapot Dome field.

Selected peak indentifications: $n-C x$, normal alkanes where $X$ is the carbon number; pr, pristane; ph, phytane. See figure 2 for sample location. 


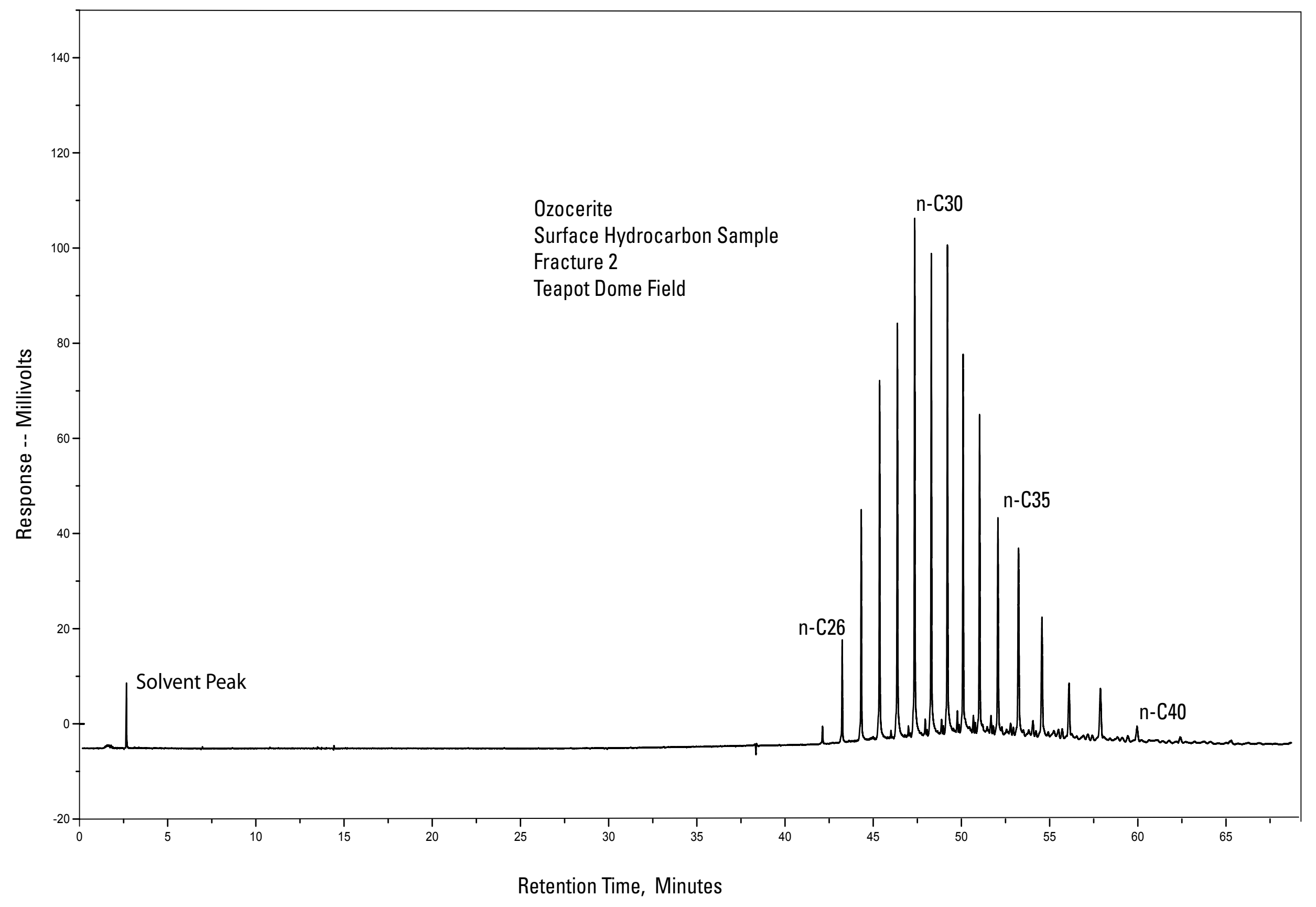

Figure 43: Ozocerite gas chromatogram, Surface Hydrocarbon Sample, Fracture 2, Teapot Dome field.

Selected peak indentifications: $\mathrm{n}-\mathrm{Cx}$, normal alkanes where $\mathrm{X}$ is the carbon number; pr, pristane; ph, phytane. See figure 2 for sample location. 


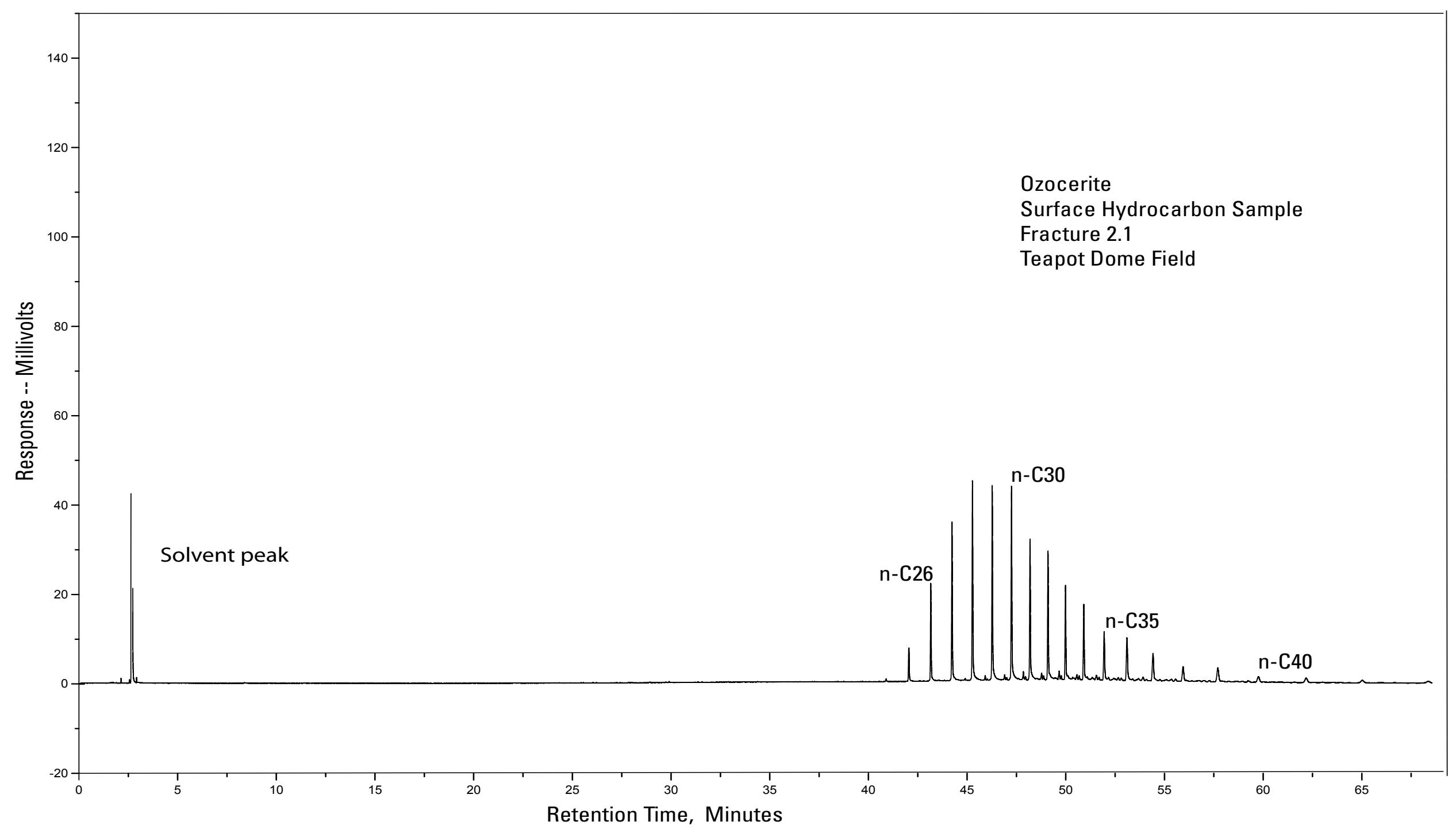

Figure 44: Ozocerite gas chromatogram, Surface Hydrocarbon Sample, Fracture 2.1, Teapot Dome field.

Selected peak indentifications: $n-C x$, normal alkanes where $X$ is the carbon number; pr, pristane; ph, phytane. See figure 2 for sample location. 
Table 1. Selected Well Information

Average depths of producing formations were calculated from top and bottom perforation data, available from the Wyoming Oil and Gas Conservation website, http://wogcc.state.wy.us.

\begin{tabular}{|c|c|c|c|c|c|c|c|c|c|c|}
\hline Well Name & $\begin{array}{l}\text { Producing } \\
\text { Horizon }\end{array}$ & $\begin{array}{l}\text { Formation } \\
\text { (Fm.) }\end{array}$ & $\begin{array}{l}\text { Lithology of } \\
\text { Producing } \\
\text { Horizon }\end{array}$ & $\begin{array}{l}\text { Avg. Depth } \\
\text { of Producing } \\
\text { Horizon (ft.) }\end{array}$ & Field & API number & Lat. & Long. & $\begin{array}{l}\text { Sample } \\
\text { Type }\end{array}$ & $\begin{array}{l}\text { Sampling } \\
\text { Date }\end{array}$ \\
\hline \multicolumn{11}{|c|}{ Cretaceous Formations } \\
\hline $5231 S \times 10^{*}$ & $\begin{array}{l}\text { Shannon Ss. } \\
\text { Mbr. }\end{array}$ & Cody Sh. & Sandstone & 174 & $\begin{array}{l}\text { Teapot } \\
\text { Dome }\end{array}$ & 4902511248 & 43.2828 & 106.20037 & oil & 9/20/2005 \\
\hline $6136 S \times 10^{*}$ & $\begin{array}{l}\text { Shannon Ss. } \\
\text { Mbr. }\end{array}$ & Cody Sh. & Sandstone & 304 & $\begin{array}{l}\text { Teapot } \\
\text { Dome }\end{array}$ & 4902511153 & $43 . .28309$ & 106.19793 & oil & $9 / 20 / 2004$ \\
\hline $6216 S \times 3^{*}$ & $\begin{array}{l}\text { Shannon Ss. } \\
\text { Mbr. }\end{array}$ & Cody Sh. & Sandstone & 407 & $\begin{array}{l}\text { Teapot } \\
\text { Dome }\end{array}$ & 4902511273 & 43.29558 & 106.1987 & oil & $9 / 20 / 2004$ \\
\hline $6235 \times 3^{*}$ & $\begin{array}{l}\text { Shannon Ss. } \\
\text { Mbr. }\end{array}$ & Cody Sh. & Sandstone & 432 & $\begin{array}{l}\text { Teapot } \\
\text { Dome }\end{array}$ & 4902522516 & 43.29709 & 106.19781 & oil & 9/20/2004 \\
\hline $135 \times 3$ & $\begin{array}{l}\text { Shannon Ss. } \\
\text { Mbr. }\end{array}$ & Cody Sh. & Sandstone & 481.5 & $\begin{array}{l}\text { Teapot } \\
\text { Dome }\end{array}$ & 4902510284 & 43.29462 & 106.21071 & oil & $9 / 20 / 2004$ \\
\hline $38 S 34$ & $\begin{array}{l}\text { Shannon Ss. } \\
\text { Mbr. }\end{array}$ & Cody Sh. & Sandstone & 496 & $\begin{array}{l}\text { Teapot } \\
\text { Dome }\end{array}$ & 4902510683 & 43.30007 & 106.20512 & oil & $9 / 20 / 2004$ \\
\hline 77 S34 & $\begin{array}{l}\text { Shannon Ss. } \\
\text { Mbr. }\end{array}$ & Cody Sh. & Sandstone & 499 & $\begin{array}{l}\text { Teapot } \\
\text { Dome }\end{array}$ & 4902510347 & 43.30193 & 106.19537 & oil & $9 / 20 / 2004$ \\
\hline $28 S \times 2$ & $\begin{array}{l}\text { Shannon Ss. } \\
\text { Mbr. }\end{array}$ & Cody Sh. & Sandstone & 521 & $\begin{array}{l}\text { Teapot } \\
\text { Dome }\end{array}$ & 4902506394 & 43.28602 & 106.18795 & oil & $9 / 20 / 2004$ \\
\hline $24 S \times 2$ & $\begin{array}{l}\text { Shannon Ss. } \\
\text { Mbr. }\end{array}$ & Cody Sh. & Sandstone & 628 & $\begin{array}{l}\text { Teapot } \\
\text { Dome }\end{array}$ & 4902510557 & 43.29291 & 106.18707 & oil & $9 / 20 / 2004$ \\
\hline $43 S \times 14$ & $\begin{array}{l}\text { Shannon Ss. } \\
\text { Mbr. }\end{array}$ & Cody Sh. & Sandstone & 733 & $\begin{array}{l}\text { Teapot } \\
\text { Dome }\end{array}$ & 4902510636 & 43.26648 & 106.18298 & oil & 9/20/2004 \\
\hline $25 S T X 23$ & Steele Sh. & Cody Sh. & Siltstone & 2510 & $\begin{array}{l}\text { Teapot } \\
\text { Dome }\end{array}$ & 4902511190 & 43.2904 & 106.20664 & oil & $6 / 15 / 2004$ \\
\hline 27SHX14 & Niobrara Mbr. & Cody Sh. & Calcareous Sh. & 2337 & $\begin{array}{l}\text { Teapot } \\
\text { Dome }\end{array}$ & 4902511180 & 43.25976 & 106.18882 & oil & $6 / 15 / 2004$ \\
\hline 26STX10 & $\begin{array}{l}\text { Niobrara /Steele } \\
\text { Sh. }\end{array}$ & Cody Sh. & $\begin{array}{l}\text { Calcareous Sh. } \\
\text { /Siltstone }\end{array}$ & 1840 & $\begin{array}{l}\text { Teapot } \\
\text { Dome }\end{array}$ & 4902511074 & 43.27431 & 106.20672 & gas, oil & $6 / 15 / 2004$ \\
\hline 84A20 & $\begin{array}{l}\text { Second Wall } \\
\text { Creek Sand }\end{array}$ & Frontier Fm. & Sandstone & 2715.5 & $\begin{array}{l}\text { Teapot } \\
\text { Dome }\end{array}$ & 4902510302 & 43.33588 & 106.23258 & oil & $9 / 20 / 2004$ \\
\hline 15AX11 & $\begin{array}{l}\text { Second Wall } \\
\text { Creek Sand }\end{array}$ & Frontier Fm. & Sandstone & 2908 & $\begin{array}{l}\text { Teapot } \\
\text { Dome }\end{array}$ & 4902511054 & 43.27725 & 106.18989 & oil & 9/20/2004 \\
\hline $77 \mathrm{AX} 20$ & $\begin{array}{l}\text { Second Wall } \\
\text { Creek Sand }\end{array}$ & Frontier Fm. & Sandstone & 2974 & $\begin{array}{l}\text { Teapot } \\
\text { Dome }\end{array}$ & 4902510884 & 43.33049 & 106.23421 & oil & $9 / 20 / 2004$ \\
\hline 87AX3 & $\begin{array}{l}\text { Second Wall } \\
\text { Creek Sand }\end{array}$ & Frontier Fm. & Sandstone & 2997 & $\begin{array}{l}\text { Teapot } \\
\text { Dome }\end{array}$ & 4902510851 & 43.29673 & 106.192 & oil & $9 / 20 / 2004$ \\
\hline
\end{tabular}

* = In area affected by steamflood operations terminated in late 1995--early 1996. Personal communication, RMOTC personnel, 3/27/05. 
Table 1. Selected Well Information (cont.)

Average depths of producing formations were calculated from top and bottom perforation data, available from the Wyoming Oil and Gas Conservation website, http://wogcc.state.wy.us.

\begin{tabular}{|c|c|c|c|c|c|c|c|c|c|c|}
\hline Well Name & $\begin{array}{l}\text { Producing } \\
\text { Horizon }\end{array}$ & $\begin{array}{l}\text { Formation } \\
\text { (Fm.) }\end{array}$ & $\begin{array}{l}\text { Lithology of } \\
\text { Producing } \\
\text { Horizon }\end{array}$ & $\begin{array}{l}\text { Avg. Depth } \\
\text { of Producing } \\
\text { Horizon (ft.) }\end{array}$ & Field & API number & Lat. & Long. & $\begin{array}{l}\text { Sample } \\
\text { Type }\end{array}$ & $\begin{array}{l}\text { Sampling } \\
\text { Date }\end{array}$ \\
\hline \multicolumn{11}{|c|}{ Cretaceous Formations (cont.) } \\
\hline $32 \mathrm{~A} \times 10$ & $\begin{array}{l}\text { Second Wall } \\
\text { Creek Sand }\end{array}$ & Frontier Fm. & Sandstone & 2998 & $\begin{array}{l}\text { Teapot } \\
\text { Dome }\end{array}$ & 4902510946 & 4328170 & 106.2042 & gas, oil & $6 / 15 / 2004$ \\
\hline $14 \mathrm{~A} \times 11$ & $\begin{array}{l}\text { Second Wall } \\
\text { Creek Sand }\end{array}$ & Frontier Fm. & Sandstone & 3035 & $\begin{array}{l}\text { Teapot } \\
\text { Dome }\end{array}$ & 4902511047 & 43.27847 & 106.18984 & oil & 9/20/2004 \\
\hline $38 \mathrm{~A} \times 34$ & $\begin{array}{l}\text { Second Wall } \\
\text { Creek Sand }\end{array}$ & Frontier Fm. & Sandstone & 3101 & $\begin{array}{l}\text { Teapot } \\
\text { Dome }\end{array}$ & 4902510856 & 43.30076 & 106.20532 & oil & $9 / 20 / 2004$ \\
\hline $36 \mathrm{~A} \times 34$ & $\begin{array}{l}\text { Second Wall } \\
\text { Creek Sand }\end{array}$ & Frontier Fm. & Sandstone & 2908 & $\begin{array}{l}\text { Teapot } \\
\text { Dome }\end{array}$ & 4902511032 & 43.30411 & 106.20503 & oil & 9/20/2004 \\
\hline $83 A \times 10^{* *}$ & $\begin{array}{l}\text { Second Wall } \\
\text { Creek Sand }\end{array}$ & Frontier Fm. & Sandstone & 3000 & $\begin{array}{l}\text { Teapot } \\
\text { Dome }\end{array}$ & 4902510398 & 43.28041 & 106.19199 & oil & 9/20/2004 \\
\hline $\begin{array}{l}\text { Anadarko } \\
\text { Commingled }\end{array}$ & $\begin{array}{l}\text { Second Wall } \\
\text { Creek Sand }\end{array}$ & Frontier Fm. & Sandstone & na & $\begin{array}{l}\text { Salt } \\
\text { Creek }\end{array}$ & na & na & na & oil & $9 / 21 / 2004$ \\
\hline $72 T \times 33$ & $\begin{array}{l}\text { Third Wall Creek } \\
\text { Sand }\end{array}$ & Frontier Fm. & $\begin{array}{l}\text { Shaley } \\
\text { Sandstone }\end{array}$ & 3060 & $\begin{array}{l}\text { Teapot } \\
\text { Dome }\end{array}$ & 4902510881 & 43.31129 & 106.21499 & gas, oil & $6 / 15 / 2004$ \\
\hline Gas Plant Inlet & $\begin{array}{l}\text { Muddy Ss. and } \\
\text { 2nd Wall Creek }\end{array}$ & & Sandstone & na & $\begin{array}{l}\text { Teapot } \\
\text { Dome }\end{array}$ & na & na & na & gas & $6 / 15 / 2004$ \\
\hline $85 \mathrm{M} \times 10^{\star \star *}$ & Muddy Ss. & Muddy Ss. & Sandstone & 3725.5 & $\begin{array}{l}\text { Teapot } \\
\text { Dome }\end{array}$ & 4902510958 & 43.2766 & 106.19721 & gas & $6 / 15 / 2004$ \\
\hline $11 D \times 26$ & $\begin{array}{l}\text { Fall River Fm. } \\
\text { (Dakota) }\end{array}$ & $\begin{array}{l}\text { Inyan Kara } \\
\text { Group }\end{array}$ & Sandstone & 4964 & $\begin{array}{l}\text { Teapot } \\
\text { Dome }\end{array}$ & 4902511012 & 43.24196 & 106.18972 & gas, oil & $6 / 15 / 2004$ \\
\hline \multicolumn{11}{|c|}{ Pennsylvanian Formation } \\
\hline 55TPX10 & Tensleep Ss. & Tensleep Ss. & $\begin{array}{l}\text { Calcareous } \\
\text { Sandstone }\end{array}$ & 5432 & $\begin{array}{l}\text { Teapot } \\
\text { Dome }\end{array}$ & 4902510778 & 43.27691 & 106.19953 & oil & $9 / 21 / 2004$ \\
\hline 671TPX10 & Tensleep Ss. & Tensleep Ss. & $\begin{array}{l}\text { Calcareous } \\
\text { Sandstone }\end{array}$ & 5528 & $\begin{array}{l}\text { Teapot } \\
\text { Dome }\end{array}$ & 4902523040 & 43.27273 & 106.19721 & oil & $9 / 21 / 2004$ \\
\hline Commingled & Tensleep Ss. & Tensleep Ss. & $\begin{array}{l}\text { Calcareous } \\
\text { Sandstone }\end{array}$ & na & $\begin{array}{l}\text { Teapot } \\
\text { Dome }\end{array}$ & na & na & na & oil & $6 / 15 / 2004$ \\
\hline 432TPX10 & Tensleep Ss. & Tensleep Ss. & $\begin{array}{l}\text { Calcareous } \\
\text { Sandstone }\end{array}$ & 5413 & $\begin{array}{l}\text { Teapot } \\
\text { Dome }\end{array}$ & 4902511207 & 43.2798 & 106.20265 & oil & $9 / 21 / 2004$ \\
\hline 72TPX10 & Tensleep Ss. & Tensleep Ss. & $\begin{array}{l}\text { Calcareous } \\
\text { Sandstone }\end{array}$ & 5485 & $\begin{array}{l}\text { Teapot } \\
\text { Dome }\end{array}$ & 4902522808 & 43.28303 & 106.19538 & oil & 9/21/2004 \\
\hline $\begin{array}{l}\text { Anadarko } \\
\text { Commingled }\end{array}$ & Tensleep Ss. & Tensleep Ss. & $\begin{array}{l}\text { Calcareous } \\
\text { Sandstone }\end{array}$ & na & $\begin{array}{l}\text { Salt } \\
\text { Creek }\end{array}$ & na & na & na & oil & $9 / 21 / 2004$ \\
\hline
\end{tabular}

** = affected by gas reinjection which reinjects stripped gas from the Muddy Ss. and Second Wall Creek "Sand". Personal communication, RMOTC personnel, 4/9/05.

na $=$ not applicable $\mathrm{nr}=$ not reported 
Table 2. Selected bulk characteristics of oil samples from the Teapot Dome field.

$$
\mathrm{nr}=\text { not reported } \mathrm{nc}=\text { not calculated }
$$

Shannon Sandstone Wells

\begin{tabular}{|c|c|c|c|c|c|c|c|c|}
\hline Well \# & $\begin{array}{l}\text { API } \\
\text { Gravity }\end{array}$ & $\begin{array}{l}\text { Wt \% } \\
\text { Saturates }\end{array}$ & $\begin{array}{l}\text { Wt \% } \\
\text { Aromatics }\end{array}$ & $\begin{array}{l}\text { Wt \% } \\
\text { NSO }\end{array}$ & $\begin{array}{l}\text { Wt \% } \\
\text { ASPH }\end{array}$ & $\begin{array}{l}\text { Wt \% } \\
\text { Sulfur }\end{array}$ & $\begin{array}{l}\delta^{13} \mathbf{C} \\
\text { Aromatics }\end{array}$ & $\begin{array}{l}\delta^{13} \mathrm{C} \\
\text { Saturates }\end{array}$ \\
\hline $52-31 S \times 10$ & 33.68 & 60.72 & 9.04 & 1.59 & 0.76 & 0.08 & -27.49 & -28.74 \\
\hline 61-36SX10 & 32.70 & 64.39 & 10.85 & 1.43 & 0.48 & 0.06 & -27.49 & -28.75 \\
\hline $62-16 S \times 3$ & 28.88 & 68.77 & 9.16 & 1.67 & 1.59 & 0.06 & -27.39 & -28.67 \\
\hline $62-3 S \times 3$ & 29.92 & 64.85 & 9.40 & 2.24 & 2.23 & 0.09 & -27.36 & -28.61 \\
\hline $13 S \times 3$ & 31.89 & 59.33 & 9.48 & 2.10 & 0.89 & 0.11 & -27.58 & -28.85 \\
\hline $38-S-34$ & 29.29 & 58.37 & 10.94 & 1.81 & 1.02 & 0.06 & -27.40 & -28.62 \\
\hline 77534 & 29.42 & 63.52 & 11.09 & 1.74 & 1.58 & 0.50 & -27.30 & -28.53 \\
\hline $28 S \times 2$ & 32.67 & 67.43 & 11.59 & 1.77 & 0.58 & 0.06 & -27.46 & -28.73 \\
\hline $24 S \times 2$ & 30.92 & 63.01 & 8.58 & 1.69 & 0.59 & 0.11 & -27.27 & -28.52 \\
\hline $43 S \times 14$ & 35.83 & 60.56 & 8.19 & 1.73 & 1.36 & 0.08 & -27.23 & -28.51 \\
\hline Avg. $(n=10)$ & 31.52 & 63.09 & 9.83 & 1.78 & 1.11 & 0.12 & -27.40 & -28.65 \\
\hline Std.Dev. & 2.25 & 3.41 & 1.18 & 0.24 & 0.57 & 0.13 & 0.11 & 0.11 \\
\hline \multicolumn{9}{|c|}{ Cretaceous Shale Wells } \\
\hline & API & Wt \% & Wt \% & Wt \% & Wt \% & Wt \% & $\delta^{13} \mathrm{C}$ & $\delta^{13} \mathbf{C}$ \\
\hline Well \# & Gravity & Saturates & Aromatics & NSO & ASPH & Sulfur & Aromatics & Saturates \\
\hline $25 S T \times 23$ & 37.83 & 75.95 & 9.93 & 1.95 & $<1$ & 0.20 & -27.75 & -28.94 \\
\hline 26STX10 & 36.00 & 70.90 & 9.41 & 2.71 & $<1$ & 0.09 & -27.63 & -28.74 \\
\hline 27SHX14 & 36.52 & 67.43 & 9.42 & 3.66 & 1.46 & 0.28 & -27.59 & -28.85 \\
\hline Avg. $(n=3)$ & 36.78 & 71.43 & 9.58 & 2.77 & $\mathrm{nc}$ & 0.19 & -27.66 & -28.84 \\
\hline Std.Dev. & 0.94 & 4.28 & 0.30 & 0.86 & $\mathrm{nc}$ & 0.10 & 0.08 & 0.10 \\
\hline \multicolumn{9}{|c|}{ Wall Creek "Sand" Wells } \\
\hline & API & Wt \% & Wt \% & Wt \% & Wt \% & Wt \% & $\delta^{13} \mathrm{C}$ & $\delta^{13} \mathrm{C}$ \\
\hline Well \# & Gravity & Saturates & Aromatics & NSO & ASPH & Sulfur & Aromatics & Saturates \\
\hline $84 A-20$ & $\mathrm{nr}$ & 57.78 & 10.02 & 2.10 & 1.86 & 0.06 & -27.06 & -28.17 \\
\hline $15 \mathrm{~A} \times 11$ & $\mathrm{nr}$ & 70.53 & 9.82 & 1.05 & 1.73 & 0.03 & -26.99 & -28.27 \\
\hline 77-AX20 & 31.38 & 57.22 & 9.87 & 2.20 & 3.06 & 0.07 & -27.08 & -28.00 \\
\hline 87-AX3 & $\mathrm{nr}$ & 60.94 & 9.60 & 1.89 & 1.57 & 0.04 & -27.12 & -28.31 \\
\hline $32 A \times 10$ & 33.07 & 73.69 & 7.30 & 1.87 & 0.87 & 0.07 & -27.08 & -28.19 \\
\hline $14 \mathrm{~A} \times 11$ & 33.10 & 66.04 & 8.73 & 1.02 & 0.51 & 0.05 & -27.04 & -28.30 \\
\hline $38-A X-34$ & 32.24 & 60.43 & 10.63 & 1.83 & 0.58 & 0.04 & -26.92 & -28.20 \\
\hline 36-AX34 & 43.01 & 59.74 & 10.62 & 1.97 & 0.68 & 0.05 & -26.90 & -28.34 \\
\hline 83AX10 & 33.38 & 68.12 & 9.94 & 1.93 & 0.83 & 0.04 & -27.09 & -28.40 \\
\hline $72 T \times 33$ & 34.26 & 69.35 & 9.07 & 7.00 & 1.10 & 0.08 & -27.09 & -28.22 \\
\hline Avg. $(n=10)$ & 34.35 & 64.38 & 9.56 & 2.28 & 1.28 & 0.05 & -27.04 & -28.24 \\
\hline Std.Dev. & 3.92 & 5.87 & 0.99 & 1.70 & 0.79 & 0.02 & 0.08 & 0.11 \\
\hline \multicolumn{9}{|c|}{ Dakota Sandstone Well } \\
\hline & API & Wt \% & Wt \% & Wt \% & Wt \% & Wt \% & $\delta^{13} \mathrm{C}$ & $\delta^{13} \mathrm{C}$ \\
\hline Well \# & Gravity & Saturates & Aromatics & NSO & ASPH & Sulfur & Aromatics & Saturates \\
\hline \multicolumn{9}{|c|}{ Tensleep Sandstone Wells } \\
\hline & API & Wt \% & Wt \% & Wt \% & Wt \% & Wt \% & $\delta^{13} \mathrm{C}$ & $\delta^{13} \mathrm{C}$ \\
\hline Well \# & Gravity & Saturates & Aromatics & NSO & ASPH & Sulfur & Aromatics & Saturates \\
\hline 55-TPX-10 & $\mathrm{nr}$ & 55.34 & 14.02 & 2.42 & 6.33 & 1.70 & -29.14 & -29.46 \\
\hline 67-1-TPX-10 & $\mathrm{nr}$ & 48.32 & 14.93 & 1.68 & 6.13 & 1.48 & -29.11 & -29.58 \\
\hline Treater & 30.84 & 55.05 & 12.50 & 11.25 & 3.92 & 0.75 & -29.24 & -29.64 \\
\hline 43-2-TPX-10 & $\mathrm{nr}$ & 51.60 & 13.53 & 2.96 & 4.48 & 1.59 & -29.22 & -29.59 \\
\hline 72-TPX-10 & 29.57 & 56.10 & 15.92 & 1.18 & 7.43 & 1.20 & -29.22 & -29.55 \\
\hline Avg. $(n=5)$ & 30.84 & 53.28 & 14.18 & 3.90 & 5.66 & 1.34 & -29.19 & -29.56 \\
\hline Std.Dev. & $\mathrm{nc}$ & 3.27 & 1.31 & 4.17 & 1.43 & 0.38 & 0.06 & 0.07 \\
\hline \multicolumn{9}{|c|}{ Statistical results for Denver Organic Geochem Lab Analysis } \\
\hline In-house Oil & & & & & & & & \\
\hline $\begin{array}{l}\text { Standard } \\
(n=11)\end{array}$ & $\begin{array}{l}\text { API } \\
\text { Gravity }\end{array}$ & $\begin{array}{l}\text { Wt \% } \\
\text { Saturates }\end{array}$ & $\begin{array}{l}\text { Wt \% } \\
\text { Aromatics }\end{array}$ & $\begin{array}{l}\text { Wt \% } \\
\text { NSO }\end{array}$ & $\begin{array}{l}\text { Wt \% } \\
\text { ASPH }\end{array}$ & $\begin{array}{l}\text { Wt \% } \\
\text { Sulfur }\end{array}$ & $\begin{array}{l}\delta^{13} \mathrm{C} \\
\text { Aromatics }\end{array}$ & $\begin{array}{l}\delta^{13} \mathrm{C} \\
\text { Saturates }\end{array}$ \\
\hline Avg. & 37.62 & $\mathrm{nr}$ & $\mathrm{nr}$ & $\mathrm{nr}$ & $\mathrm{nr}$ & $\mathrm{nr}$ & -26.66 & -28.47 \\
\hline Std.Dev. & 0.01 & $\mathrm{nr}$ & $\mathrm{nr}$ & $\mathrm{nr}$ & $\mathrm{nr}$ & $\mathrm{nr}$ & 0.06 & 0.04 \\
\hline
\end{tabular}


Table 3. Peak area ratios used in Figures 35 and 36.

\begin{tabular}{|c|c|c|c|c|c|c|c|c|c|}
\hline \multicolumn{6}{|c|}{ Shannon Sandstone Wells } & \multicolumn{4}{|c|}{ Cretaceous Shale Wells } \\
\hline Well \# & $n-\mathrm{C}_{7} / \mathrm{MCH}$ & $\mathrm{Pr} / \mathrm{Ph}$ & Prln $-C_{17}$ & $\mathrm{Ph} / n-\mathrm{C}_{18}$ & Well \# & $n-\mathrm{C}_{7} / \mathrm{MCH}$ & Pr/Ph & Prln $-\mathrm{C}_{17}$ & $\mathrm{Ph} / n-\mathrm{C}_{18}$ \\
\hline $5231 S \times 10$ & 0.36 & 1.81 & 0.96 & 0.58 & $25 S T \times 23$ & 0.82 & 1.91 & 0.81 & 0.51 \\
\hline $6136 S \times 10$ & 0.12 & 1.81 & 0.99 & 0.58 & 26STX10 & 0.69 & 1.88 & 0.83 & 0.52 \\
\hline $6216 S \times 3$ & 0.18 & 1.88 & 1.08 & 0.55 & $27 \mathrm{SHX} 14$ & 0.74 & 1.82 & 0.81 & 0.51 \\
\hline $6235 \times 3$ & 0.23 & 1.81 & 1.14 & 0.59 & Avg. $(n=3)$ & 0.75 & 1.87 & 0.81 & 0.51 \\
\hline $13 S \times 3$ & 0.39 & 1.81 & 1.01 & 0.58 & Std.Dev. & 0.07 & 0.05 & 0.01 & 0.01 \\
\hline $38 S 34$ & 0.13 & 1.80 & 1.21 & 0.61 & & & & & \\
\hline 77534 & 0.10 & 1.81 & 1.10 & 0.58 & & & & & \\
\hline $28 S \times 2$ & 0.34 & 1.82 & 0.92 & 0.52 & & & & & \\
\hline $24 S \times 2$ & 0.24 & 1.80 & 0.96 & 0.53 & & Dakot & ta Sand & Istone We & \\
\hline $43 S \times 14$ & 0.42 & 1.91 & 0.90 & 0.56 & Well \# & $n-\mathrm{C}_{7} / \mathrm{MCH}$ & Pr/Ph & Prln $-\mathrm{C}_{17}$ & $\mathrm{Ph} / n-\mathrm{C}_{18}$ \\
\hline $\begin{array}{l}\text { Avg. } \\
(n=10)\end{array}$ & 0.25 & 1.83 & 1.03 & 0.57 & 11DX26 & 0.67 & 1.63 & 0.80 & 0.56 \\
\hline Std.Dev. & 0.12 & 0.04 & 0.10 & 0.03 & & & & & \\
\hline & Wall C & sreek "s & Sand" Wel & & & & & & \\
\hline Well \# & $n-\mathrm{C}_{7} / \mathrm{MCH}$ & Pr/Ph & Prln $-C_{17}$ & $\mathrm{Ph} / n-\mathrm{C}_{18}$ & & & & & \\
\hline $84 \mathrm{~A} 20$ & 0.21 & 1.53 & 1.25 & 1.09 & & Tenslee & ep Sanc & dstone W & ells \\
\hline $15 A \times 11$ & 0.47 & 1.59 & 0.81 & 0.57 & Well \# & $n-\mathrm{C}_{7} / \mathrm{MCH}$ & $\mathrm{Pr} / \mathrm{Ph}$ & Prln- $\mathrm{C}_{17}$ & $\mathrm{Ph} / n-\mathrm{C}_{18}$ \\
\hline $77 A \times 20$ & 0.44 & 1.65 & 1.15 & 0.89 & 55TPX10 & 2.88 & 0.87 & 0.41 & 0.53 \\
\hline $87 A \times 3$ & 0.09 & 1.29 & 1.99 & 1.84 & 671TPX10 & 4.93 & 0.51 & 0.23 & 0.51 \\
\hline $32 \mathrm{~A} \times 10$ & 0.37 & 1.60 & 0.92 & 0.66 & Treater & 6.10 & 0.59 & 0.25 & 0.49 \\
\hline $14 \mathrm{~A} \times 11$ & 0.48 & 1.73 & 0.80 & 0.54 & 432TPX10 & 5.05 & 0.52 & 0.24 & 0.52 \\
\hline $38 \mathrm{~A} \times 34$ & 0.46 & 1.59 & 0.84 & 0.63 & 72TPX10 & 6.45 & 0.60 & 0.25 & 0.49 \\
\hline $36 \mathrm{~A} \times 34$ & 0.46 & 1.57 & 0.84 & 0.59 & Avg. $(n=5)$ & 5.08 & 0.62 & 0.28 & 0.51 \\
\hline $83 A \times 10$ & 0.18 & 1.57 & 1.47 & 1.31 & Std.Dev. & 1.40 & 0.15 & 0.08 & 0.02 \\
\hline $72 T \times 33$ & 0.21 & 1.47 & 1.48 & 1.08 & & & & & \\
\hline Avg. & & & & & & & & & \\
\hline$(n=10)$ & 0.34 & 1.56 & 1.15 & 0.92 & & & & & \\
\hline Std.Dev. & 0.15 & 0.12 & 0.40 & 0.42 & & & & & \\
\hline & Reproducik & oility of & f peak are & a ratios & & & & & \\
\hline $\begin{array}{l}\text { Whole } \\
\text { crude oil } \\
\text { standard }\end{array}$ & $n-\mathrm{C}_{7} / \mathrm{MCH}$ & $\mathrm{Pr} / \mathrm{Ph}$ & Prln $-C_{17}$ & $\mathrm{Ph} / n-\mathrm{C}_{18}$ & & & & & \\
\hline $\begin{array}{l}\text { Avg. } \\
(n=10)\end{array}$ & 1.01 & 1.81 & 0.42 & 0.37 & & & & & \\
\hline Std.Dev. & 0.003 & 0.077 & 0.008 & 0.370 & & & & & \\
\hline
\end{tabular}


Table 4. Molecular and Isotopic Compositions of Gas Samples from the Teapot Dome field.

\begin{tabular}{|c|c|c|c|c|c|c|c|c|c|c|}
\hline Well Name & $\begin{array}{l}\text { Producing } \\
\text { Formation } \\
\text { Niobrara/Steele }\end{array}$ & $\begin{array}{l}\text { Carbon } \\
\text { Dioxide } \\
\mathrm{CO}_{2} \\
\text { (Wt. \%) }\end{array}$ & $\begin{array}{l}\text { Carbon } \\
\text { Dioxide } \\
\delta^{13} \mathrm{C} \\
(\% \circ)\end{array}$ & $\begin{array}{l}\text { Carbon } \\
\text { Monoxide } \\
\text { CO } \\
\text { (Wt. \%) }\end{array}$ & $\begin{array}{l}\text { Helium He } \\
\text { (Wt. \%) }\end{array}$ & $\begin{array}{l}\text { Hydrogen } \\
\mathrm{H}_{2} \\
\text { (Wt. \%) }\end{array}$ & $\begin{array}{l}\text { Argon Ar } \\
\text { (Wt. \%) }\end{array}$ & $\begin{array}{l}\text { Oxygen } \\
\mathrm{O}_{2} \\
\text { (Wt. \%) }\end{array}$ & $\begin{array}{l}\text { Nitrogen } \\
\mathrm{N}_{2} \\
(\mathrm{Wt} . \%)\end{array}$ & $\begin{array}{l}\text { Nitrogen } \\
\delta^{15} \mathrm{~N} \\
(\% \circ)\end{array}$ \\
\hline $26 \mathrm{STX} 10$ & $\begin{array}{l}\text { Shale } \\
\text { Second Wall }\end{array}$ & 0.840 & -11.28 & ND & 0.0313 & 0.0024 & 0.0122 & 0.0755 & 1.76 & -6.0 \\
\hline $32 A \times 10$ & $\begin{array}{l}\text { Creek Sand } \\
\text { Third Wall }\end{array}$ & 3.01 & 6.71 & ND & 0.0148 & 0.0048 & 0.0104 & 0.0200 & 1.55 & -4.1 \\
\hline $72 \mathrm{~T} \times 33$ & $\begin{array}{l}\text { Creek Sand } \\
\text { Muddy }\end{array}$ & 4.31 & 6.04 & ND & 0.0113 & 0.0049 & 0.0585 & 0.0718 & 5.64 & -1.0 \\
\hline $85 \mathrm{M} \times 10$ & $\begin{array}{l}\text { Sandstone } \\
\text { Dakota }\end{array}$ & 3.05 & 7.77 & ND & 0.0158 & 0.0020 & 0.0139 & 0.0084 & 1.72 & -3.1 \\
\hline 11DX26 & $\begin{array}{l}\text { Sandstone } \\
\text { Muddy } \\
\text { Sandstone / } \\
\text { Second Wall }\end{array}$ & 0.950 & -17.95 & ND & 0.0164 & 0.0304 & 0.0138 & 0.0507 & 3.49 & -5.1 \\
\hline Inlet & Creek Sand & 3.05 & 7.89 & ND & 0.0157 & 0.0036 & 0.0133 & 0.0106 & 1.67 & -4.0 \\
\hline Well Name & $\begin{array}{l}\text { Methane } C_{1} \\
\text { (Wt. \%) }\end{array}$ & $\begin{array}{l}\text { Methane } \\
\delta^{13} \mathrm{C} \\
(\% \circ)\end{array}$ & $\begin{array}{l}\text { Methane } \\
\delta^{2} \mathrm{H} \\
(\% \mathrm{o})\end{array}$ & $\begin{array}{l}\text { Ethylene } \\
\mathrm{C}_{2} \mathrm{H}_{4} \\
(\mathrm{Wt.} \%)\end{array}$ & $\begin{array}{l}\text { Ethane } C_{2} \\
\text { (Wt. \%) }\end{array}$ & $\begin{array}{l}\text { Ethane } \\
\delta^{13} \mathrm{C} \\
(\% \circ)\end{array}$ & $\begin{array}{l}\text { Ethane } \\
\delta^{2} \mathrm{H} \\
(\% \circ)\end{array}$ & $\begin{array}{l}\text { Propane } \\
\mathrm{C}_{3} \\
\text { (Wt. \%) }\end{array}$ & $\begin{array}{l}\text { Propane } \\
\delta^{13} \mathrm{C} \\
(\% \circ)\end{array}$ & $\begin{array}{l}\text { Propane } \\
\delta^{2} \mathrm{H} \\
(\% \circ)\end{array}$ \\
\hline 26STX10 & 80.92 & -60.57 & -215.4 & ND & 3.53 & -37.56 & -231.4 & 5.83 & -32.51 & -178.1 \\
\hline $32 \mathrm{~A} \times 10$ & 73.73 & -50.76 & -239.4 & ND & 7.55 & -35.37 & -209.4 & 7.31 & -32.39 & -168.3 \\
\hline $72 \mathrm{TX} 33$ & 71.44 & -49.50 & -233.6 & ND & 4.55 & -31.46 & -178.0 & 5.11 & -26.25 & -138.7 \\
\hline $85 \mathrm{M} \times 10$ & 87.36 & -50.27 & -238.5 & ND & 5.26 & -34.67 & -201.0 & 1.49 & -31.62 & -163.0 \\
\hline $\begin{array}{l}\text { 11DX26 } \\
\text { Gas Plant }\end{array}$ & 46.72 & -52.90 & -234.3 & ND & 12.04 & -34.36 & -207.7 & 15.99 & -31.06 & -162.9 \\
\hline Inlet & 85.94 & -50.29 & -239.6 & ND & 5.32 & -34.64 & -202.2 & 2.11 & -31.55 & -164.0 \\
\hline Well Name & $\begin{array}{l}\text { iso-Butane iC }{ }_{4} \\
\text { (Wt. \%) }\end{array}$ & $\begin{array}{l}\text { n-Butane } \\
\mathrm{nC}_{4} \\
\text { (Wt. \%) }\end{array}$ & $\begin{array}{l}\text { n-Butane } \\
\delta^{13} \mathrm{C} \\
(\% \mathrm{o})\end{array}$ & $\begin{array}{l}\text { n-Butane } \\
\delta^{2} \mathrm{H} \\
(\% \circ)\end{array}$ & $\begin{array}{l}\text { iso- } \\
\text { Pentane } \\
\text { iC }_{5} \\
\text { (Wt. \%) }\end{array}$ & $\begin{array}{l}\text { n-Pentane } \\
\text { nC } \\
\text { (Wt. \%) }\end{array}$ & $\begin{array}{l}\text { Hexanes } \\
\mathrm{C}_{6}+ \\
\text { (Wt. \%) }\end{array}$ & & & \\
\hline 26STX10 & 1.25 & 2.94 & -30.68 & -158.6 & 0.951 & 0.923 & 0.935 & & & \\
\hline $32 \mathrm{~A} \times 10$ & 1.14 & 2.92 & -30.82 & -157.5 & 0.829 & 0.859 & 1.05 & & & \\
\hline $72 \mathrm{TX} 33$ & 2.36 & 2.19 & -28.58 & -149.4 & 1.36 & 0.938 & 1.96 & & & \\
\hline 85MX10 & 0.142 & 0.298 & -30.49 & -150.3 & 0.0774 & 0.0874 & 0.475 & & & \\
\hline $\begin{array}{l}\text { 11DX26 } \\
\text { Gas Plant }\end{array}$ & 3.20 & 8.24 & -30.31 & -143.4 & 2.88 & 3.11 & 3.27 & & & \\
\hline Inlet & 0.29 & 0.604 & -30.17 & -158.1 & 0.199 & 0.206 & 0.568 & & & \\
\hline
\end{tabular}

Chemical analysis based on standards accurate to within $2 \%$

$\delta^{13} \mathrm{C}$ reported in per mil (\%o) relative to the Vienna Peedee belemnite standard (VPDB). $\delta^{2} \mathrm{H}$ reported in per mil (\%o) relative to Vienna standard mean ocean water (VSMOW).

$\delta^{15} \mathrm{~N}$ reported in per mil (\%o) relative to air.

$\mathrm{ND}=$ Not Detected 